\title{
A Realistic Perspective on Japan's LNG Demand after Fukushima
}

\author{
Akira Miyamoto \\ Chikako Ishiguro \\ Mitsuhiro Nakamura
}

NG 62

June 2012

\section{Akira Miyamoto}

Executive Researcher, Planning Dept, Osaka Gas Co., Ltd.

e-mail:akira-miyamoto@osakagas.co.jp

\section{Chikako Ishiguro}

Senior Analyst, Planning Dept, Osaka Gas Co., Ltd

e-mail:cisiguro@osakagas.co.jp

\section{Mitsuhiro Nakamura}

Assistant Manager, LNG Trading Dept, Osaka Gas Co., Ltd e-mail:mit-nakamura@osakagas.co.jp 
The contents of this paper are the authors' sole responsibility. They do not necessarily represent the views of the Oxford Institute for

Energy Studies or any of its members.

Copyright (C) 2012

\section{Oxford Institute for Energy Studies}

(Registered Charity, No. 286084)

This publication may be reproduced in part for educational or non-profit purposes without special permission from the copyright holder, provided acknowledgment of the source is made. No use of this publication may be made for resale or for any other commercial purpose whatsoever without prior permission in writing from the Oxford Institute for Energy Studies.

ISBN

978-1-907555-50-3 


\section{Preface}

The earthquake and tsunami which left its toll of destruction and the tragic loss of life on Japan's eastern seaboard on $11^{\text {th }}$ March 2011 was a natural disaster of the highest order. The earth tremors and 17 metre wave which damaged the Fukushima nuclear power plants have been well covered by the international media. What is less appreciated is the sheer extent of the damage and disruption to Japan's industry and energy infrastructure, including non-nuclear facilities.

This working paper, methodically and in detail, addresses the extent of the impact of the events of $11^{\text {th }}$ March 2011 on Japan's energy complex and describes the policy process and political tensions which led to Japan progressively taking its nuclear power facilities off-line. At the time of writing, Japan is not producing any electricity from nuclear plant. The paper describes how, through higher utilisation of fossil fuel plant and enforced and voluntary demand conservation measures, the country has coped with this unprecedented reduction in generation capacity. The impact of higher Japanese LNG imports is one component of this response which, through changes in LNG trade-flow patterns since March 2011 has impacted not just Asian but also European natural gas markets.

Looking forward, it is expected that Japan's future energy policy will stress a reduced reliance in nuclear, emphasise renewables in order to pursue $\mathrm{CO}_{2}$ abatement goals, but in practice rely more on LNG as a fuel for power generation but also for space heating and industrial consumers. The key uncertainty is the policy-driven path of future nuclear generation. It is in this context that the paper provides a timely and robust evaluation of Japan's future LNG import requirements based, inevitably, on a range of scenarios regarding the future utilisation of operable nuclear power facilities. The paper will be of great interest to all who have an interest in the wider natural gas and LNG outlook in the increasingly 'connected' global LNG system.

I am grateful to the authors for their thoroughness and objectivity and for their wish to publish their paper under the auspices of the Oxford Institute for Energy Studies Natural Gas Research Programme.

Howard V Rogers

Oxford, June 2012 


\section{Contents}

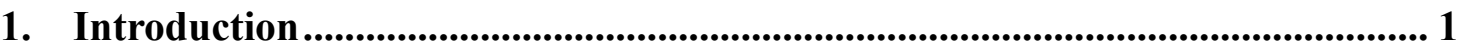

2. Developments since 11 March ....................................................................... 2

2.1 Overview of the Earthquake and Damage Caused ............................................................

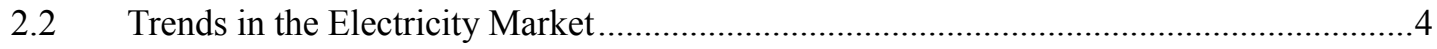

2.2.1 Extent of damage to power generation facilities in eastern Japan..............................4

2.2.2 Trends in nuclear power and load factor for reactors...............................................6

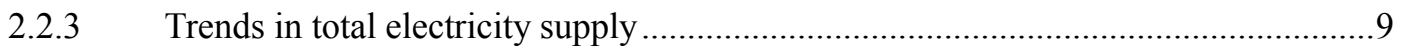

2.2.4 Trends in total electricity demand ......................................................................11

2.2.5 Trends in thermal power generation and fuel consumption .....................................13

2.2.6 LNG procurement and its impact on the international market.................................17

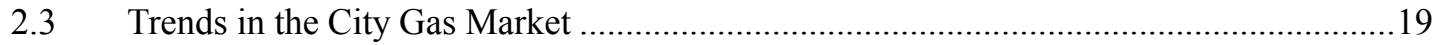

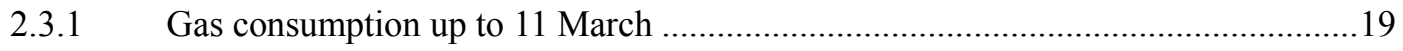

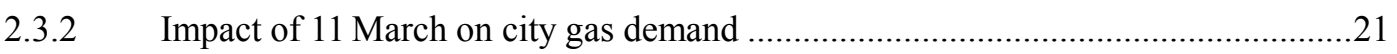

2.4 Debate on Japan's Long-Term Energy Policy ..............................................................23

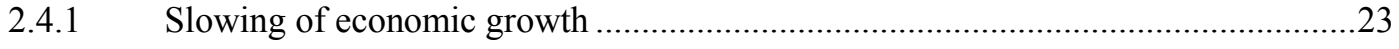

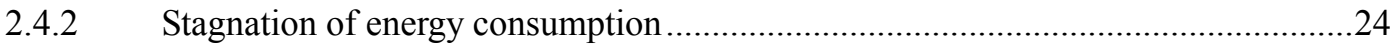

2.4.3 Comprehensive energy policy ........................................................................26

2.4.4 Changing public opinion on nuclear power and electricity market reform...............31

2.4.5 Debate on deregulation of the electricity market .....................................................32

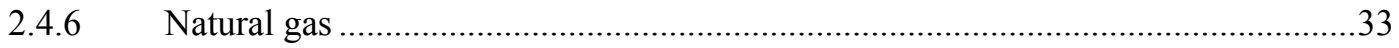

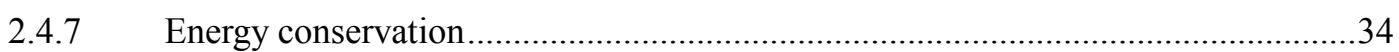

3. Estimating LNG Demand in the Electricity Generation Sector ...................... 39

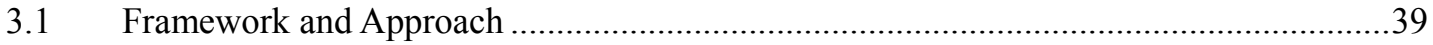

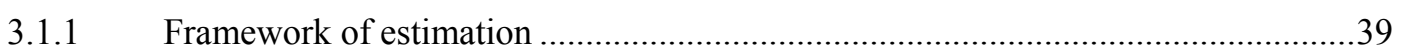

3.1.2 Electricity demand assumptions by estimating seasonal load curves .......................39

3.1.3 Main assumptions for power supply ..................................................................

3.1.4 Scenario development and assumptions.................................................................

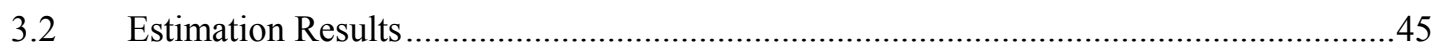

3.2.1 LNG demand outlook for the power generation sector ..........................................45

3.2.2 Observations for individual electric power companies ............................................46

4. LNG Demand Outlook for the City Gas Sector ................................................. 48

4.1 Framework for Estimation of LNG Demand in the City Gas Sector................................48

4.2 Approach and Main Assumptions for Estimating Demand ..............................................49

4.2.1 Framework for estimation of residential demand …...............................................49

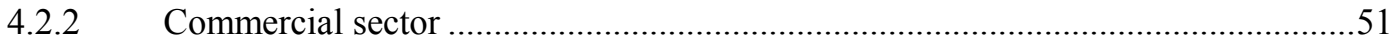

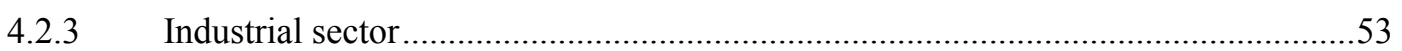

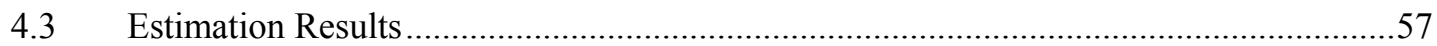

4.3.1 LNG demand outlook for the city gas sector ......................................................57

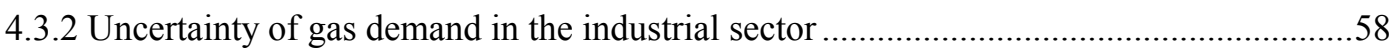


5.1 Comparison of our Estimates against Actual Demand ...................................................61

5.2 Outlook for LNG Demand in Japan after Fukushima ....................................................62

Appendix 1. Situation at Fukushima I NPS............................................................... 67

Appendix 2. Comparison of Fuel consumption by TEPCO: Shut Down of Kashiwazaki-Kariwa (2007) and Fukushima (2011) ................................................. 69

Appendix 3. Damage and Restoration of Thermal Power Capacity ........................ 71

Appendix 4. Japanese Nuclear Power Plant ........................................................... 73

Appendix 5. Emergency Power Units.................................................................................. 75

Appendix 6. Relation between Peak Load Reduction Rate and Total Demand

Estimated by the Model................................................................................................... 76

Appendix 7. Comparison of Total Demand (by peak load reduction rate) with

Supply Program for FY2010 .............................................................................. 77

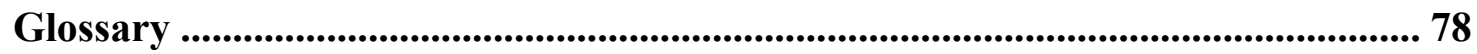

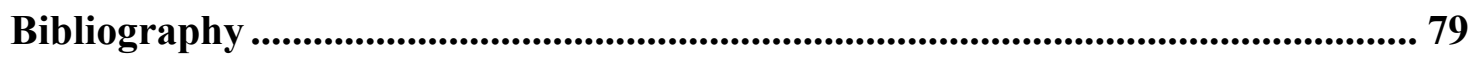

\section{Figures}

Figure 1: Map showing the extent and height of the Tsunami on March 11, 2011........ 2

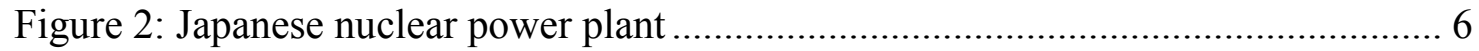

Figure 3: Historical nuclear generation volume and load factor (FY) ........................... 7

Figure 4: Monthly nuclear load factor in 2003, 2008 and 2011................................. 9

Figure 5: Demand curve for peak day in TEPCO's service area ................................ 12

Figure 6: Monthly electricity sales in Japan and by TEPCO (2010/2011) ................... 13

Figure 7: Lost nuclear power output and decline in electricity demand (TEPCO)....... 14

Figure 8: Lost nuclear power output and decline in electricity demand (Japan) .......... 14

Figure 9: Estimated power generated in 2010 and 2011 (10 EPCOs) ......................... 16

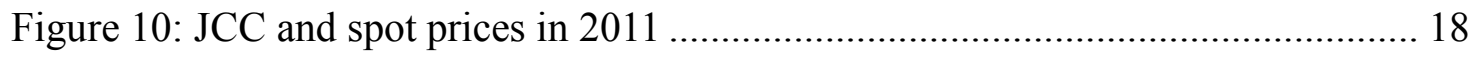

Figure 11: Trends in secondary energy and total stationary energy consumption (1990

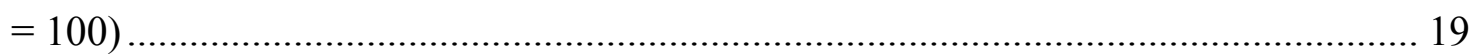

Figure 12: Long term outlook for primary energy supply (formulated prior to 11

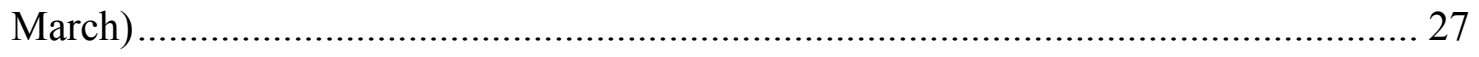

Figure 13: Long term outlook for power supply (formulated prior to $11 \mathrm{March}$ ) ........ 28

Figure 16: LNG demand estimates for the electricity generation sector - mtpa .......... 46

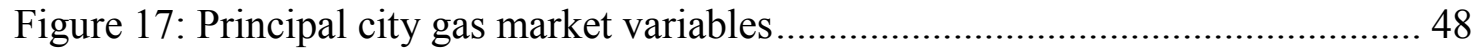

Figure 18: Approach for estimating residential demand ......................................... 49

Figure 19: Approach for estimating city gas demand in the commercial sector........... 51

Figure 20: Trends in GDP and energy consumption by source in industry $(1990=100)$ 54

Figure 21: Approach for estimating industrial demand .......................................... 55

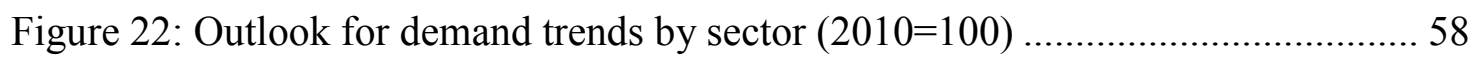


Figure 23: Trends in total energy consumption and city gas (Industrial sector).......... 58

Figure 24: Lost nuclear power and thermal fuel power output in 2007 and 2011 ........ 69

Figure 25: Year on year increase of fuel consumption in 2007and 2011 - TEPCO ..... 70

\section{Tables}

Table 1: Damage to thermal power generation capacity (see Appendix for more information) 5

Table 2: Recovery of power generation capacity by August 2011 (GW) .................... 10

Table 3: Major troubles at thermal power plants .......................................................11

Table 4: Monthly fuel consumption for electric companies - 2010/2011 (MTOE) ... 16

Table 5: Spot and short-term LNG contracts entered post-11 March .......................... 17

Table 6: Annual growth rate of GDP and energy consumption (\%) ............................ 20

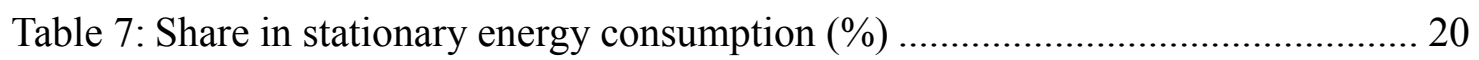

Table 8: Year-on-year changes in sales of city gas (all Japan, \%) ............................... 21

Table 9: Year-on-year changes in city gas sales in 2011 ........................................... 22

Table 10: Year-on-year changes in city gas sales of two leading utilities 2011 (\%) ..... 23

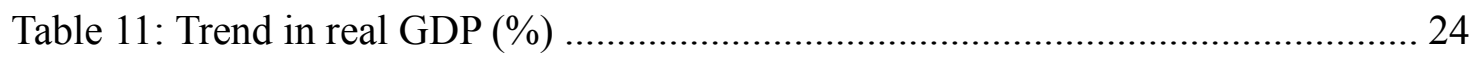

Table 12: Year-on-year change in primary energy consumption ............................... 25

Table 13: Year-on-year change in final energy consumption...................................... 26

Table 14: Change in public opinion on nuclear power $(\%)$...................................... 32

Table 15: Results of questionnaire survey of Keidanren members .............................. 36

Table 16: Peak load and power consumption compared with previous year ................. 36

Table 17: FY 2011 winter campaign to save electricity.............................................. 38

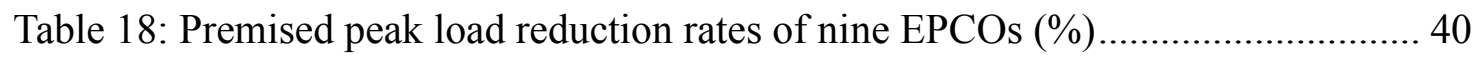

Table 19: Actual and premised peak loads of EPCOs.............................................. 41

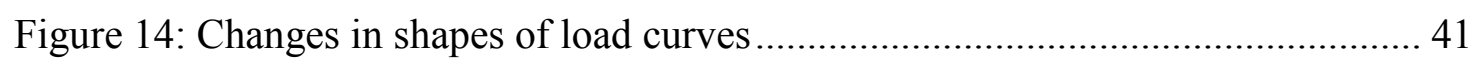

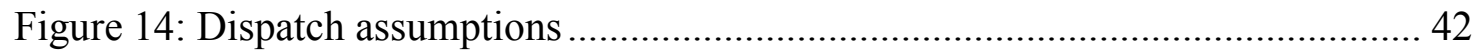

Table 20: Estimated installed capacity of 10 EPCOs' natural gas power plants (GW) 43

Table 21: Main assumptions common to all scenarios ............................................... 44

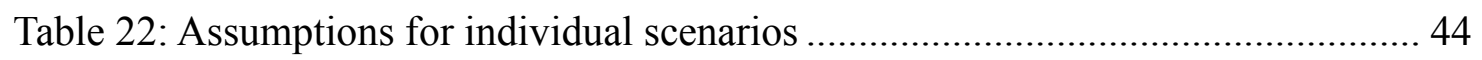

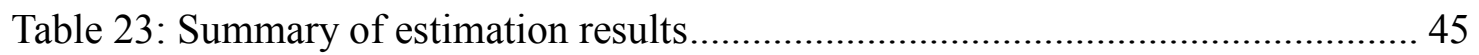

Table 24: Trends in unit gas consumption and assumptions (Residential sector)......... 50

Table 25: Trends in number of households using gas and assumptions........................50

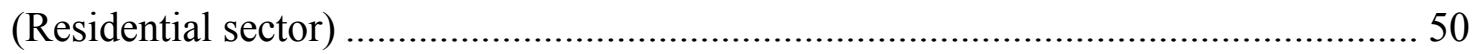

Table 26: Trends and assumptions (Commercial sector) .......................................... 52

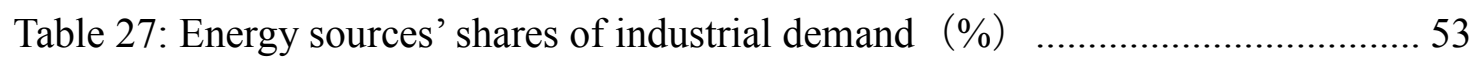

Table 28: Average annual growth rates of GDP and individual energy sources in

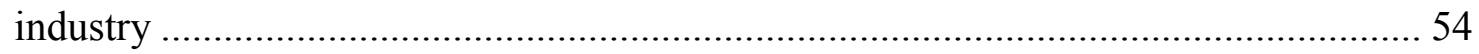

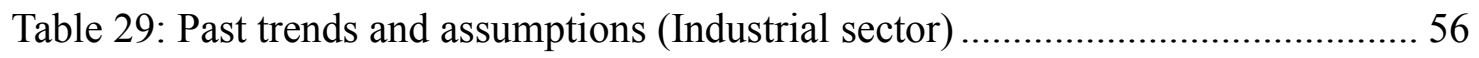

Table 30: Annual Growth Rate by sector ................................................................ 57 
Table 31: Comparison of estimates by model against actual demand 61

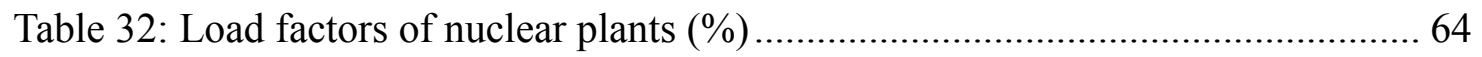

Table 33: LNG demand outlook for Japan according to estimation model .................. 65

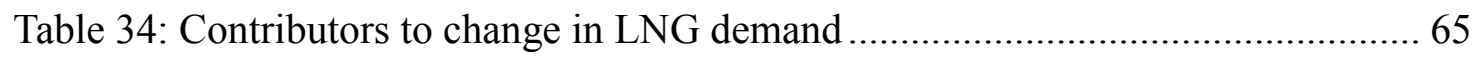

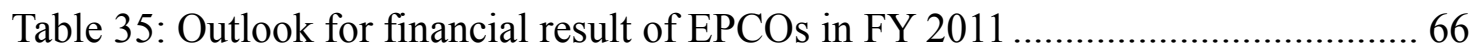

Table 36: Thermal power plants back in operation by the end of 2011 ....................... 72 


\section{Introduction}

On $11^{\text {th }}$ March 2011, Japan was struck by a massive 'once-in-a-millennium' earthquake followed by a level 7 event - the worst possible on the international scale for nuclear accidents - at the Fukushima Daiichi Nuclear Power Station ('Fukushima I NPS') . This series of disasters has had major ramifications for the world's energy markets as well as Japan, and the impact on the international LNG market has been clearly enormous.

This paper focuses on the outlook for LNG demand in the Japanese energy market given the various developments since the Fukushima crisis. While similar reports have already been published by various research institutes and experts in the year since the events of ' 3.11 ', some have made excessive estimates of demand for LNG, in our view.

A variety of issues are currently under debate in Japan, ranging from the short-term issue of bringing the existing nuclear power plants back online to the longer term question of what role nuclear power should play in energy policy in the future, and final conclusions have yet to be reached on most of these questions.

In this paper, therefore, we have taken what appear to be the most realistic premises to estimate the electricity sector's long-term demand for LNG using seasonal load curves that allow for the effects of power conservation. These estimates appear valid in comparison with actual demand since $11^{\text {th }}$ March.

This paper consists of two main parts. In the first part, we briefly summarize what happened in the energy markets following the Great East Japan Earthquake, how the energy market has changed as a result, and the nature of the debate on energy policy that has ensued. Proceeding to our main concern, we then describe in the second part of this paper our methods and the results of our estimation of long-term LNG demand in the wake of $11^{\text {th }}$ March, and the implications of our findings. As LNG demand in Japan mainly consists of demand for power generation and for city gas, sections 3 and 4 respectively explain our estimates of LNG demand in these sectors. In the concluding section, we combine these estimates to consider the outlook for LNG demand as a whole in Japan. 


\section{Developments since 11 March}

\subsection{Overview of the Earthquake and Damage Caused}

The 2011 Tohoku Earthquake ${ }^{1}$ that struck at 14:46 JST $^{2}$ on 11 March had its epicentre off the Pacific coast of the northeast part of the main island (Tohoku Region). Its magnitude, measured at 9.0, was the largest ever recorded in Japan. Massive earthquake tremors hit throughout the Tohoku region, including intensities of 7 in those parts of Miyagi Prefecture located nearest the hypo central region and high 6's in other parts of Miyagi and the prefectures of Fukushima, Ibaraki, and Tochigi (as measured on the Japanese Meteorological Agency's scale of seismic intensity). In fact, tremors ranging from 1 to low 6's were observed over the length of Japan's Pacific coast from Hokkaido in the north to Okinawa in the south (Figure 1).

Figure 1: Map showing the extent and height of the Tsunami on March 11, 2011

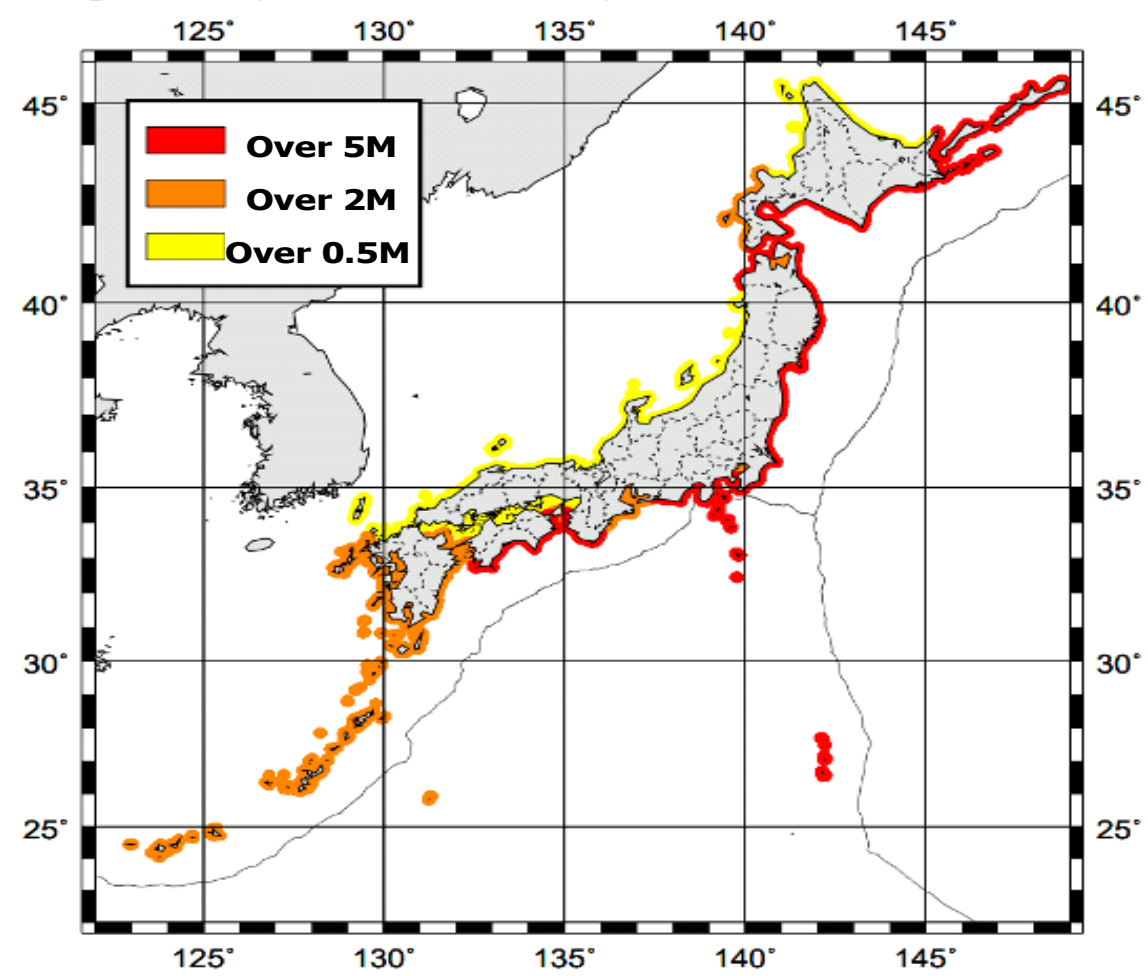

Source: Japan Weather Association

Following the earthquake, a tsunami was observed over a wide area centring on the Pacific coast from Tohoku to northern Kanto. Waves of 9.3 metres in Soma, Fukushima Prefecture, and 10 metres on the coast of Iwate Prefecture were recorded. Leaving only rubble in its path, the tsunami swept away everything, killed thousands, destroyed buildings, severed transportation links, and caused salt damage to the land. More than 670 aftershocks of magnitude over 5.0 were observed after the earthquake before the

1 Officially termed in Japan 'The 2011 off the Pacific coast of Tohoku Earthquake'

2 Japan Standard Time. 
end of 2011. The Japanese government has adopted the use of the name 'Great East Japan Earthquake'.

The damage caused by this major earthquake and massive tsunami was unprecedented. $561 \mathrm{~km}^{2}$ of land was flooded, 15,840 lives were lost, 3,547 people are missing, 5,961 people were injured, 102,886 buildings were demolished, and 58,518 buildings were partially destroyed. ${ }^{3}$

Energy infrastructure was severely damaged as well. In the power sector, approximately $7.9 \mathrm{GW}$ of power to 4.86 million customers, ${ }^{4}$ equivalent to approximately $60 \%$ of pre-quake demand, was lost in Tohoku Electric Power Co.'s ('Tohoku EPCO') service area, and up to 4.05 million customers were affected by outages in Tokyo Electric Power Co.'s ('TEPCO') service area. Distribution facilities including power plants, substations, and transmission lines were also severely damaged. Most prominently, several hours of loss of power at TEPCO's Fukushima I NPS in the aftermath of the earthquake led to a breakdown of the reactor cooling system, resulting in damage to the reactor cores. This accident, rated a "worst case" level 7 event on a par with Chernobyl on the International Nuclear Event Scale, caused immense damage, including radioactive contamination over a wide area.

In the city gas sector, around 360,000 customers in cities including Sendai, Shiogama, Ishinomaki, and Kesennuma had their supplies cut off. Some 30,000 of Tokyo Gas's customers were also affected, and a total of 420,000 customers in all suffered service disruptions. ${ }^{5}$ At Sendai City Gas Bureau's Minato LNG Terminal, the pipeline system and gas manufacturing facilities were damaged, making it impossible to receive LNG supplies. Due to the extent of the damage and difficulty of bringing facilities back online, Sendai City Gas made use of spare capacity on Tohoku Natural Gas Co.'s ${ }^{6}$ pipeline between Niigata and Sendai to bring in supplies from Nihonkai LNG's terminal on the Japan Sea coast in order to recommence gas service. Japan Petroleum Exploration is expected to supply around 110 million $\mathrm{m}^{3}$ of gas to Sendai City Gas in fiscal year 2011 by this pipeline.

Repairs to the Minato LNG Terminal, have since progressed, enabling a Malaysian shipment of LNG, the first since 11 March, to be received on 29 November. Repairs were completed in March 2012. ${ }^{7}$

\footnotetext{
${ }^{3}$ Investigation Committee on the Accident at the Fukushima Nuclear Power Stations of Tokyo Electric Power Company, $26^{\text {th }}$ Dec 2011, Interim Report. http://icanps.go.jp/post-1.html

4 Blackout caused by Tohoku Earthquake and the outlook for restoration' $21^{\text {st }}$ March,2011. http://www.tohoku-epco.co.jp/news/normal/1182682_1049.html

5 'State of Interruption of City Gas Supply', The Japan Gas Association, 11th March 2011. http://www.gas.or.jp/tohoku/press/pdf/20110313-01.pdf

6 Tohoku Natural Gas Co. is owned by The Japan Petroleum Exploration and Tohoku EPCO.

7 www.gas.city.sendai.jp/family/news/uploads/f_honoo_114.pdf, TEX Report, 30 ${ }^{\text {th }}$ Nov, 2011,
} 
LPG supplies to 1.66 million customers were also cut off, while 2.29 million customers suffered water outages. Oil refineries and other facilities in coastal regions also experienced major damage ${ }^{8}$.

\subsection{Trends in the Electricity Market}

\subsubsection{Extent of damage to power generation facilities in eastern Japan}

The power generation capacity of Japan's electric utilities at the time of the Tohoku Earthquake consisted of $49 \mathrm{GW}$ from nuclear power, $147 \mathrm{GW}$ from thermal power, and $46 \mathrm{GW}$ from hydroelectric power. Of the $101 \mathrm{GW}^{9}$ generated by plants owned by TEPCO, Tohoku EPCO, and other power wholesalers in the affected regions (consisting of $22 \mathrm{GW}$ from nuclear power, $58 \mathrm{GW}$ from thermal power, $7 \mathrm{GW}$ from hydroelectric power and the remainder pumped-storage and renewables capacity), approximately $52 \mathrm{GW}$ of capacity (primarily thermal and nuclear) was damaged and taken offline. As a result, these utilities' supply capacity was more than halved to 49 GW.

Extent of damage to thermal power plants: As most of the thermal power plants in eastern Japan are located on the Pacific coast, damage was severe and widespread. Many were flooded by the tsunami, which inundated them with soil and debris and caused severe damage to turbines and other equipment. Oil refineries suffered damage, coal unloading facilities collapsed, and coal carriers sank, thus affecting fuel supplies. As a result, $18 \mathrm{GW}$ out of a total of $58 \mathrm{GW}$ of thermal power capacity was affected. Broken down by type of fuel used, around one third $(6.8 \mathrm{GW})$ of total oil-fired thermal capacity of $16 \mathrm{GW}$ was affected, while a very significant $7.5 \mathrm{GW}$ out of a total of 10 GW of coal-fired thermal capacity was lost. The combination of reduced dependence on coal as a base-load power source and shutdown of nuclear power plants had a major impact on electricity supply capacity. LNG-fired power plants, on the other hand, were mainly located further away from the epicentre, and as a consequence only $3.5 \mathrm{GW}$ out of a total capacity of $31 \mathrm{GW}$ was affected.

\footnotetext{
http://www.texreport.co.jp/

8 'Securing supply of LP Gas for Tohoku region' $5^{\text {th }}$ May 2011. http://www.meti.go.jp/press/2011/03/20120307002/20120307002-2.pdf. 'Damage and response' Ministry of Health, Labour and Welfare, Web site http://www.mhlw.go.jp/jishin/116-3-1.html

${ }^{9}$ Calculated based on data published by METI, 'Framework of balancing power demand and supply during the summer season'.
} 
Table 1: Damage to thermal power generation capacity (see Appendix for more information)

\begin{tabular}{|c|c|c|c|c|}
\hline GW & All Japan* & East Japan**(A) & Damaged**(B) $^{*}$ & A-B** \\
\hline Thermal power & 147 & 58 & 18 & 40 \\
\hline Coal & 37 & 10 & 7.5 & 2.5 \\
\hline Oil & 66 & 16 & 6.8 & 9.2 \\
\hline LNG & 45 & 31 & 3.5 & 27.5 \\
\hline
\end{tabular}

Sources: * Based on data published on METI web site and Okinawa EPCO's website. ** Various sources such as newspapers \& companies 'web sites

Extent of damage to hydroelectric power plants: There was little damage to hydroelectric power plants, with Tohoku EPCO, for example, reporting rock falls and similar damage at four locations. TEPCO shut down its hydroelectric power plants at more than 20 locations, but all came back online a few days after the earthquake.

Extent of damage to nuclear power plants: Similarly, $14 \mathrm{GW}$ of the region's $22 \mathrm{GW}$ of nuclear power capacity is located on the Pacific coast (the exception being Kashiwazaki-Kariwa NPS, which faces the Sea of Japan). Of this capacity, the following ten reactors with capacities totalling $8.9 \mathrm{GW}$ were in operation when the earthquake struck: TEPCO's Units 1, 2, and 3 at Fukushima I NPS and Units 1 through 4 at its Fukushima II NPS; Tohoku EPCO's Units 1, 2, and 3 at Onagawa NPS; and Japan Atomic Power's (JAPC) Tokai II NPS ${ }^{10}$.

Despite the huge tremors experienced, all reactors at these plants were successfully scrammed $^{11}$ and core cooling commenced. Cooling was subsequently maintained at all plants except Units 1, 2, 3, and 4 at Fukushima I NPS. Fukushima I NPS experienced an upper 6 tremor followed 45 minutes later by a tsunami reaching a maximum height of 17 metres that led to the successive loss of offsite power, diesel generators, and then battery power. As a result, the cooling systems failed and damage was caused to the reactor cores (For details, see Appendix 1).

\footnotetext{
${ }^{10}$ Unit 2 at Onagawa, Higashidori (Tohoku EPCO), Unit 4, 5 \& 6 at Fukushima I (TEPCO) were not in operation due to regular inspection.

11 A scram is an emergency shutdown of a nuclear reactor
} 
Figure 2: Japanese nuclear power plant

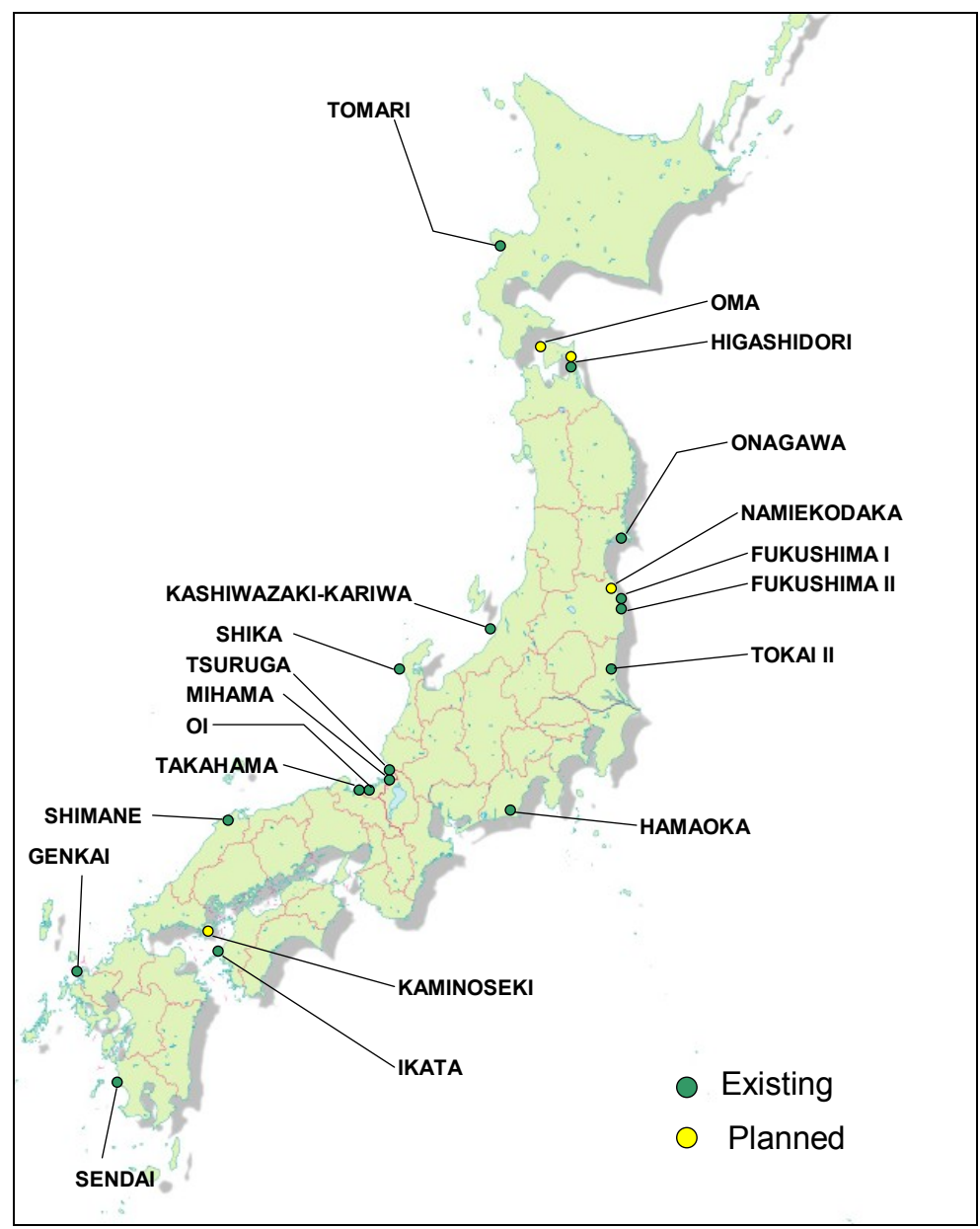

Source: EPCOs'Web site

\subsubsection{Trends in nuclear power and load factor for reactors}

Japan presently has 54 nuclear power facilities, the load factor for which was comparatively stable from the1980s and remained at a high annual rate of $80 \%$ from 1995. As Figure 3 shows, however, it has been on the decline since the early 2000s.

In 2002, TEPCO was found to have filed false reports on regular inspections of Unit 1 at Fukushima I NPS. ${ }^{12}$ The government ordered TEPCO to shut down all its plants by 15 April 2003. In addition, as problems arose at other utilities' nuclear power plants concurrently, Japan's nuclear power plant load factor fell below 50\% to $44 \%$ in May 2003.

In July 2007, the Chuetsu offshore earthquake ${ }^{13}$ occurred. Immediately after the earthquake, all generators at TEPCO's Kashiwazaki-Kariwa NPS were safely shut down, but the load factor again declined until 2008 due to damage sustained by the facilities.

\footnotetext{
12 'Interim report on data falsification of the nuclear plant self-inspection' 1st October, 2002. http://www.meti.go.jp/report/downloadfiles/g21108b012j.pdf

${ }^{13}$ The earthquake occurred in the offshore of Niigata prefecture on 16 July 2007 with M6.8.
} 
Figure 3: Historical nuclear generation volume and load factor (FY)
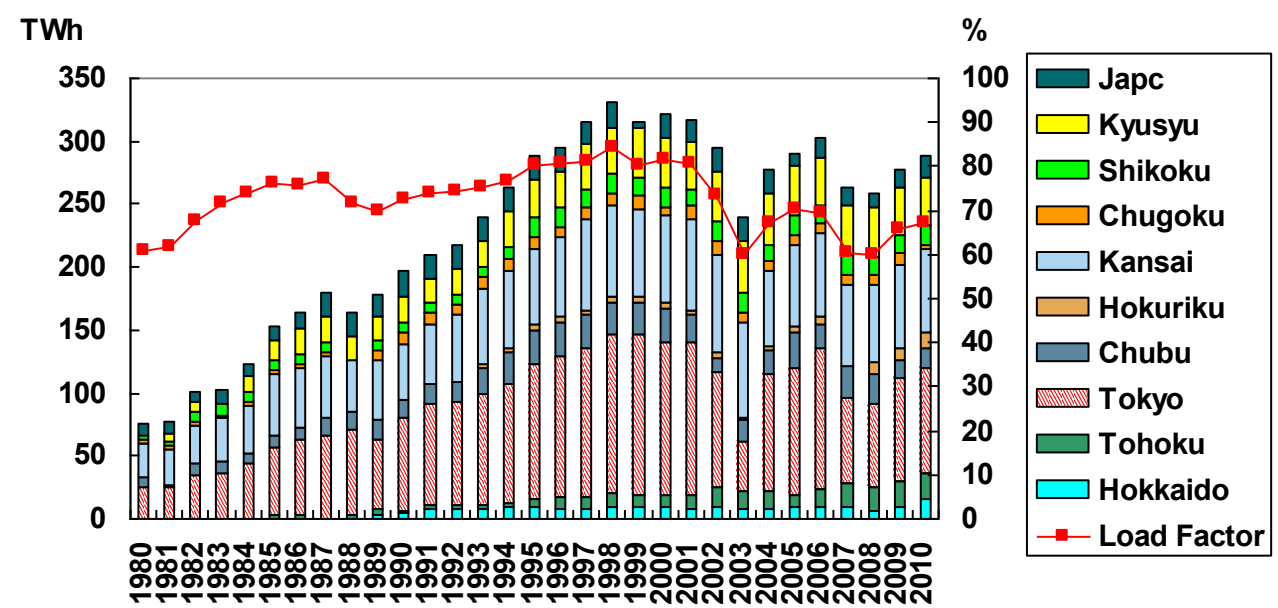

Source: Statistics of Electricity, METI Web site

The year before the 11 March earthquake, the load factor stood at $68 \%$ (all Japan) and output amounted to $290 \mathrm{TWh}$, equivalent to approximately $30 \%$ of electricity demand in Japan. If we look at the trend following 11 March, we find that 15 reactors ${ }^{14}$ operated by TEPCO, Tohoku EPCO, and JAPC were offline from the day of the earthquake and that the load factor in April fell to 50\%.

After that, however, as a result of continued government confusion over how to tackle the nuclear crisis, one after another of Japan's nuclear power plants were forced to shut down. At the end of March, the Ministry of Economy, Trade and Industry (METI) instructed operators to strengthen measures to ensure safety. ${ }^{15}$ In early May, based on the reports that they filed in response, METI gave permission for the plants' continued operation and resumption of operation after shutdown for regular inspection. The same day, however, the prime minister abruptly called on Chubu EPCO to shut down Hamaoka NPS. Although this request was without legal foundation and the reasons for the risks were ambiguous, Chubu EPCO complied and manually shut down Hamaoka NPS's Unit 4 on 13 May and Unit 5 on 14 May. (Unit 3 was offline at the time.) As a result, Japan's nuclear plant load factor fell to $36 \%$ in June.

Because Hamaoka NPS's shutdown caused an increasing number of local governments to become suspicious of the central government's assessment of the safety of nuclear power plants across the country, METI again indicated that it would allow plants to be restarted provided that new additional safety measures were implemented. Immediately

\footnotetext{
147 reactors at Kashiwazaki-Kariwa NPS are not included

15 The government required six measures when power was lost due to the tsunami, such as a measure to secure emergency power source.
} 
thereafter on 6 July, however, the prime minister unexpectedly directed that 'stress tests' quite different from the above safety measures be conducted.

These stress tests were set to consist of two stages; a primary assessment of safety margins against the events beyond the design basis would be implemented at plants in shutdown for regular inspection, and a secondary assessment consisting of comprehensive safety measures would be imposed on all plants in operation. The recommencement of operations at plants shut down for regular inspection was made conditional upon completion of the primary assessment. ${ }^{16}$

However, as no clear standards of judgment were set and restart after completion of the primary assessment phase also required local government approval, the prospect of a rapid return to service after the completion of regular inspections receded.

As of the end of February 2012, Units 3 and 4 at Kansai EPCO's Oi NPS completed the primary assessment by Japan's Nuclear and Industrial Safety Agency (NISA), and another 14 reactors were in the process of being inspected. ${ }^{17}$

Consequently, only Unit 3 at Hokkaido EPCO's Tomari NPS, which had been in the test operation after a regular inspection, has been able to come back on line since 11 March (912 MW of plants restarted commercial operation on 17 August). As shown in Figure 4, Japan's nuclear power load factor, which had stood at $70.8 \%$ when the earthquake struck, had fallen to $15.3 \%$ in December as plants were shut down for their regularly scheduled inspections every 13 months. The remaining operating plants have been progressively taken offline by the beginning of May 2012, resulting in the loss of at least $20 \%$ of Japan's electricity supply capacity. ${ }^{18}$ The decline in the load factor for nuclear power in 2011 was unprecedented and greater even than during the previous lows in 2003 and 2008.

\footnotetext{
${ }^{16}$ NISA (Japan's Nuclear and Industrial Safety Agency) Press release 22 July 2011, http://www.nisa.meti.go.jp/english/press/ NISA assessments must be approved as appropriate by the Nuclear Safety Commission of Japan. NISA and IAEA concluded that the stress test method is appropriate but the Nuclear Safety Commission said evaluation of the stress test was not enough to assess the reactors' safety, on $20 \mathrm{Feb}$.

17 NISA: http://www.nisa.meti.go.jp/stresstest/stresstest.html

${ }^{18}$ See appendix 7
} 
Figure 4: Monthly nuclear load factor in 2003, 2008 and 2011

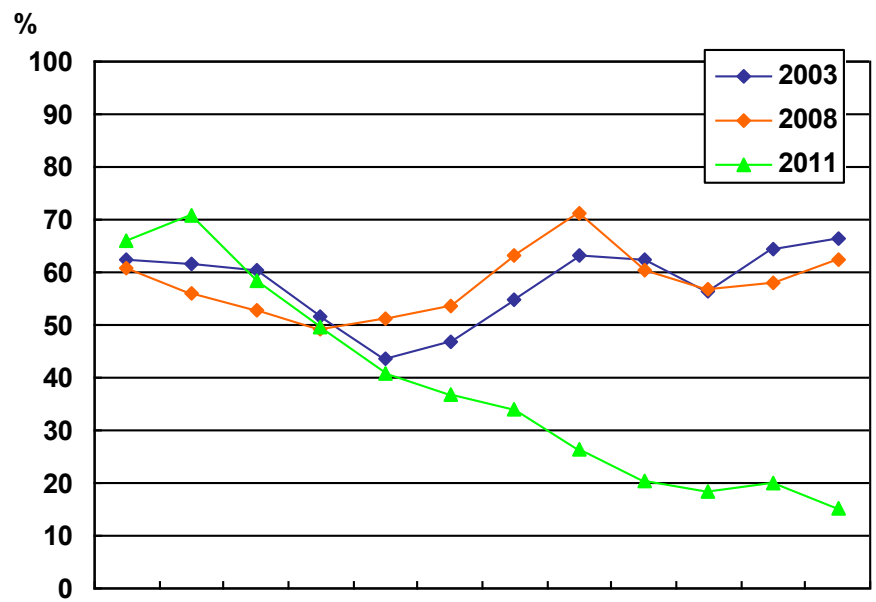

Jan Feb Mar Apr May Jun Jul Aug Sep Oct Nov Dec

Source: Statistics of Electricity, METI Web-site

\subsubsection{Trends in total electricity supply}

In addition to the physical damage to power plants in eastern Japan, the subsequent confusion over nuclear power policy rendered Japan's electricity supply situation extremely precarious. A variety of means were used to cope with the serious shortfall in supply capacity in respect of peak midsummer demand, and Japan just made it through the summer of 2011 without prolonged black-outs.

According to data published by EPCOs, supply capacity in eastern Japan at the end of March 2011 fell from $101 \mathrm{GW}$ to $47 \mathrm{GW}{ }^{19}$ As damage caused by the disaster was severe, an early resumption of operations at most power plants was initially thought unlikely. Due also to factors such as limited inter-regional transmission capacity and frequency differences between east and west Japan, ${ }^{20}$ the amount of power that could be supplied from neighbouring regions was limited to around $1 \mathrm{GW}$.

However, damaged thermal power capacity was brought back online extraordinarily rapidly, and all TEPCO's power plants except its nuclear facilities had resumed operations by July. ${ }^{21}$ In addition, other measures taken by TEPCO included the restarting of mothballed facilities, installation of emergency power units, and increased procurement from private power generators, enabling capacity to be increased to 54

\footnotetext{
${ }^{19}$ Including wholesalers' supply capacity. Capacity of TEPCO was once reduced to $31 \mathrm{GW}$ and Tohoku Electric to $11 \mathrm{GW}$, in the aftermath of the earthquake. TEPCO pulled up its capacity to $36 \mathrm{GW}$ until the end of March. METI's report on 8 April. 'Framework of balancing power demand and supply during the summer season,' http://www.meti.go.jp/earthquake/electricity_supply/0408_electricity_supply_01_00.pdf

${ }^{20} 50 \mathrm{~Hz}$ (east) and $60 \mathrm{~Hz}$ (west)

21 Tohoku EPCO restored approximately $80 \%$ of outages three days after the earthquake, and $94 \%$ eight days later. Power outages in all areas where restoration work could be performed were recovered by 18 June (Central Disaster Prevention Council data).
} 
GW (at the end of July) and 55 GW (at the end of August) ahead of the high demand season. Tohoku EPCO made similar efforts and as a consequence by the summer, these companies' capacity had recovered to $69 \mathrm{GW}$. The situation regarding the resumption of damaged power plants is summarized in Appendix 3.

With regard to newly constructed generation facilities as emergency power sources, various types of equipment, including gas turbines, gas engines, and diesel generators, were provided by manufacturers on a priority basis, and power generating facilities were also provided voluntarily by Korea and Thailand. The rapid recovery in supply capacity was due to the efforts of many parties behind the scenes.

Meanwhile, in order to cope with a serious power shortage, METI took exceptional measures to defer the regular inspections of thermal power plants specified under the Electricity Business Act in order to achieve a high operation rate of thermal power plants. It also exempted expansion of thermal power facilities from environmental impact assessments ${ }^{22}$ in order to expedite the development of new sources of supply. The government also adopted measures for self-generators to subsidize fuel procurement and the new installation of generation facilities, enabling TEPCO to purchase $1.6 \mathrm{GW}$ and Tohoku EPCO to purchase $200 \mathrm{MW}$ of surplus power.

On the other hand, as the lack of functional power generation capacity required the operation of power plants at excessively high utilization rate and the restarting of aging facilities, breakdowns in facilities frequently occurred and power generation stoppages were widespread (see Table 3).

Table 2: Recovery of power generation capacity by August 2011 (GW)

\begin{tabular}{|l|c|c|}
\hline & Tokyo / Tohoku & All Japan \\
\hline Restoration of damaged capacity & 12.4 & 12.4 \\
\hline Rescheduling of regular inspections & 0.9 & 2.2 \\
\hline Restoration of mothballed thermal capacity & 1.2 & 2.0 \\
\hline Procurement from private power generators & 1.8 & 2.9 \\
\hline Emergency power units & 1.5 & 1.5 \\
\hline Total & 17.8 & 21.0 \\
\hline
\end{tabular}

Source: various industry/media sources

\footnotetext{
${ }^{22}$ Environmental assessment for construction of new power generation facilities with a capacity of 112 MW or more normally takes around three years. Elimination of this requirement enabled new construction in a matter of months.
} 
Table 3: Major troubles at thermal power plants

\begin{tabular}{|l|c|c|c|c|}
\hline Power plant & Fuel & Capacity $(\mathrm{MW})$ & Company & Date of trouble \\
\hline Maizuru 1 & Coal & 900 & Kansai & May-29 \\
\hline Himeji 2-5 & LNG & 600 & Kansai & Jul-2 \\
\hline Turuga 2 & Coal & 700 & Hokuriku & Jul-8 \\
\hline Owari-Mita 3 & Oil & 500 & Chubu & Jul-20 \\
\hline Kajima 4 & Oil & 600 & Tokyo & Jul-27 \\
\hline Karita 1 & Coal & 375 & Kyusyu & Aug-4 \\
\hline Misumi 1 & Coal & 1000 & Chugoku & Aug-9 \\
\hline Sakai 2 & LNG & 400 & Kansai & Aug-13 \\
\hline Sakaide 1 & LNG & 300 & Shikoku & Aug-16 \\
\hline Akita 2 & Oil & 350 & Tohoku & Aug-17 \\
\hline Shin-Kokura 4 & LNG & 600 & Kyusyu & Aug-24 \\
\hline Kajima 4 & Oil & 600 & Tokyo & Nov-29 \\
\hline Isogo 12 & Coal & 1200 & J-power & Nov-25 \\
\hline Noshiro & Coal & 600 & Tohoku & Dec-9 \\
\hline Kamaishi & Coal & 136 & Nippon Steel & Dec-13 \\
\hline
\end{tabular}

Source: Various industry/media sources

\subsubsection{Trends in total electricity demand}

TEPCO faced a major supply shortfall of $10 \mathrm{GW}$ relative to expected peak demand of $41 \mathrm{GW}$ immediately following the earthquake. Rolling blackouts were consequently imposed for 10 weekdays from 14 to 28 March in its service area. ${ }^{23}$ After that, the supply-demand situation subsequently eased as Japan entered the low-demand season, enabling further rolling blackouts to be avoided.

In the summer demand season, however, a 5-6 GW shortfall relative to peak load of 60 GW was forecast in TEPCO's area despite efforts to bring more capacity online. As Tohoku EPCO faced a similar shortage of capacity to meet peak load, the government imposed restrictions on electricity use under Article 27 of the Electricity Business Act between the hours of 09:00 and 20:00 for 50 weekdays from 1 July to 9 September in TEPCO's service area (and to 2 September in Tohoku EPCO's service area). Invoked for the first time since the oil crisis in 1973, this article required large corporate users of $500 \mathrm{~kW}$ or more to reduce power consumption by $15 \%$ from their maximum demand of the previous year. Various campaigns were also run urging other users to cut electricity consumption (see next section for details).

Thanks to these efforts, peak load was reduced by $15.8 \%$ in the Tohoku region and by $18 \%$ in the Tokyo region. Power saving at all times of the day, as well by those subject

23 Municipalities were divided into five groups (excluding the 23 wards of Tokyo) with rolling blackouts lasting three hours each according to the state of supply and demand. 
to the above restrictions on peak hours, depressed TEPCO's total sales of electricity in August by $16.8 \%$.

Demand in other regions was similarly cut in July and August, though reductions remained voluntary rather than a legal obligation, and consequently the power saving rate was less than $10 \%$. As a result, electricity demand in Japan as a whole shrank $11.8 \%$ in August. Over the year as a whole, voluntary cuts in demand continued, causing a demand reduction of $10.8 \%$ in TEPCO's service area and $7.0 \%$ in Japan as a whole.

Figure 5: Demand curve for peak day in TEPCO's service area

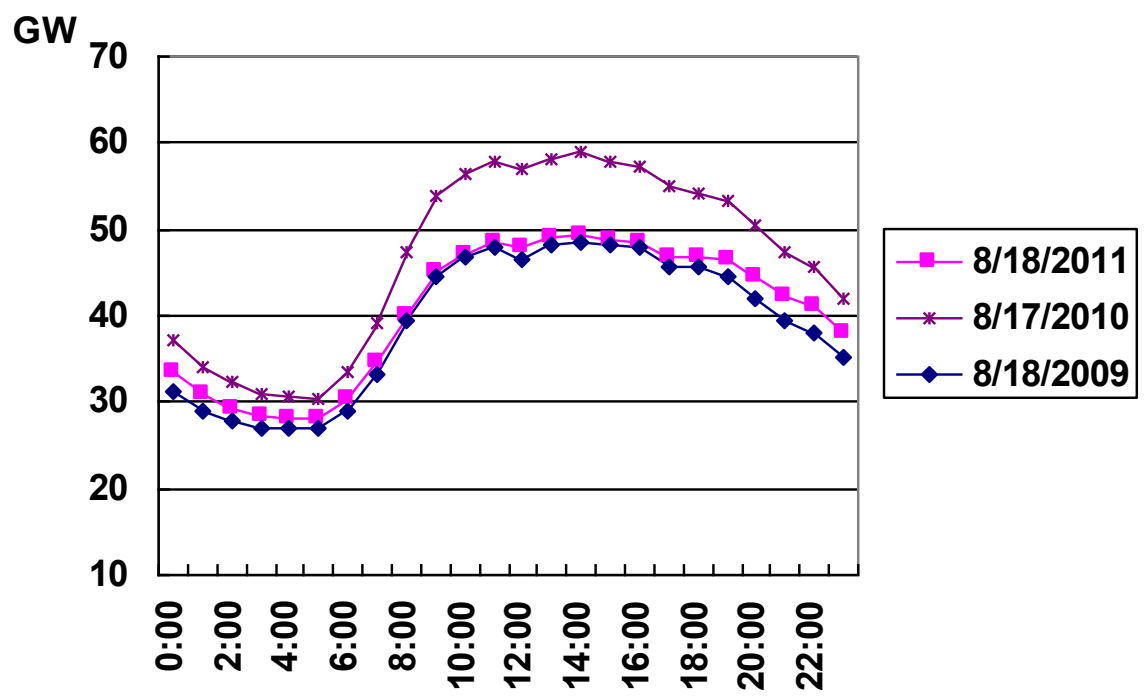

Source: TEPCO Web site 
Figure 6: Monthly electricity sales in Japan and by TEPCO (2010/2011)
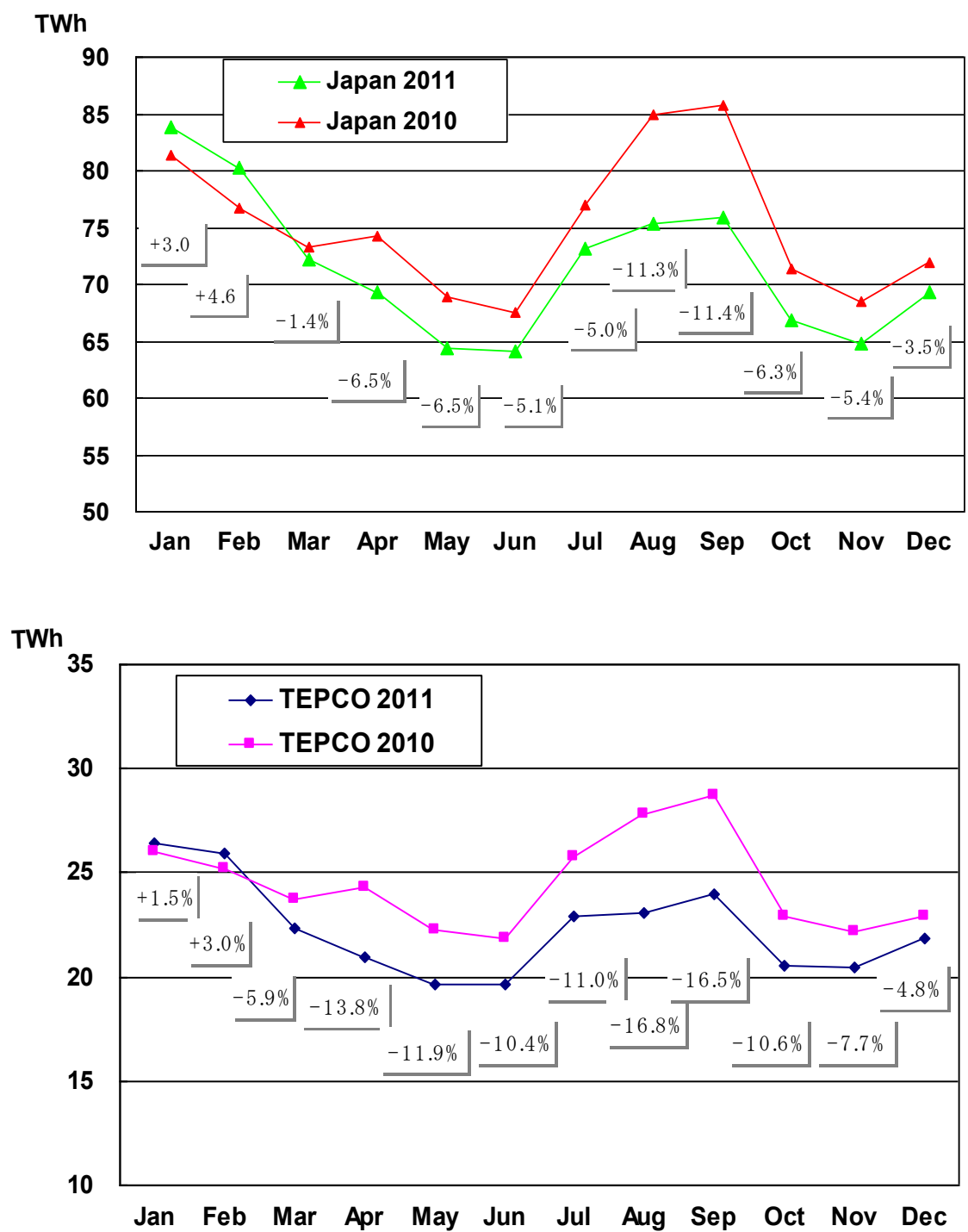

Source: Statistics of Electricity, METI Web site

\subsubsection{Trends in thermal power generation and fuel consumption}

The electric utilities and companies in related industries thus drew on all of their resources to try to ensure sufficient electricity supply to meet demand. As anticipated, demand still outstripped supply capacity, however adjustments - i.e., power conserving measures - were made on the demand side. How effective these measures were is evident from the supply and demand balance in TEPCO's service area. Figure 7 shows changes in nuclear power output and total electricity demand compared with a year earlier. From March till summer, while nuclear power output (shown by the red line) plunged, electricity demand (shown by the blue line) also decreased as various energy saving efforts were made. The crucial point is that the deficit created by the loss of nuclear power was virtually covered by cuts in demand, and the actual electricity shortfall (shown by the shaded section in Figure 7) was remarkably limited. Indeed, although Units 1 and 7 at the Kashiwazaki-Kariwa NPS were taken offline for regular 
inspection in August, the maximum demand of $49 \mathrm{GW}$ was significantly less than the anticipated peak demand. Thus, TEPCO had sufficient margin to engage in power interchange with Tohoku EPCO.

A similar trend is apparent in regions across the rest of Japan that were not directly affected by the earthquake (see Figure 8). Because measures for energy savings in these regions were taken on only a voluntary basis, the gap was comparatively larger than TEPCO's, and widened by the progressive shutdown of nuclear power plants in western Japan, which is more dependent on nuclear power.

Figure 7: Lost nuclear power output and decline in electricity demand (TEPCO)

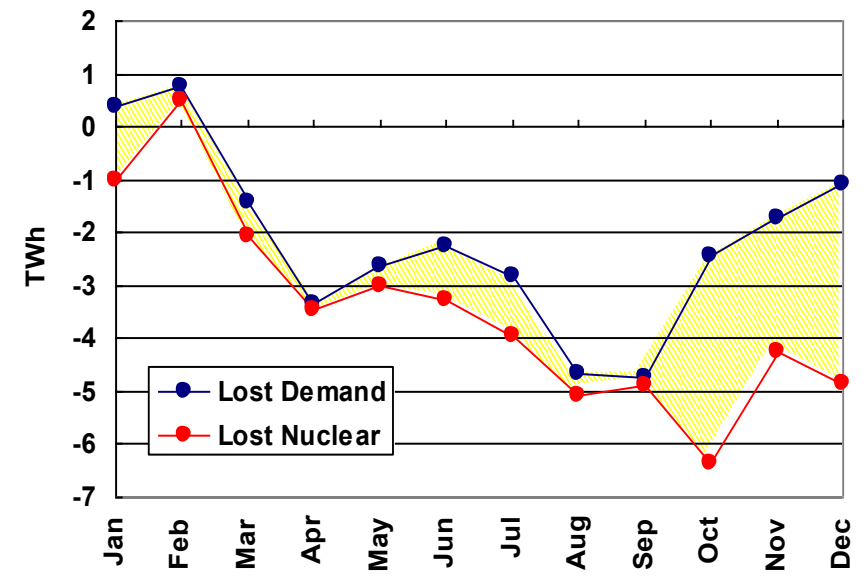

Source: Statistics of Electricity, METI Web site

Figure 8: Lost nuclear power output and decline in electricity demand (Japan)

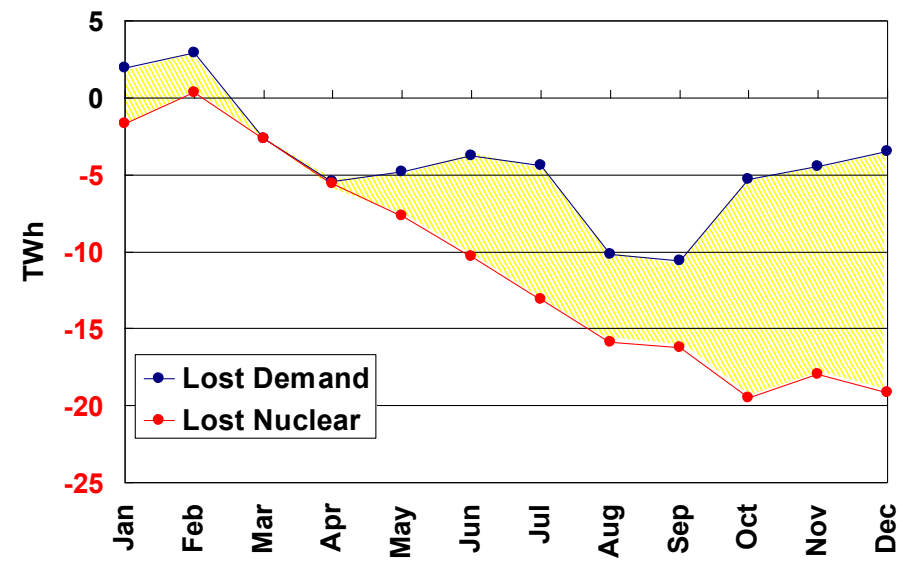

Source: Statistics of Electricity, METI Web site

Looking at changes in monthly fuel consumption in Japan (Table 4), we find that coal consumption largely fell from a year earlier throughout the period shown. This is because many coal power plants were affected by the earthquake. The load factor for coal as well as nuclear power fell as a result, and the significant loss of base load power is apparent also from the statistics on fuel consumption. 
As for oil, while heavy fuel oil consumption had not increased significantly, consumption of crude oil more than doubled from a year earlier between March and May. During the July-August period when electricity shortages were most feared, growth in the consumption of both heavy fuel oil and crude oil was low. Both then grew strongly in October through December. This was basically because shortly after the earthquake, power generation capacities were limited to oil thermal plants in the affected region and crude oil had been one of the important substitution sources. In summer, however, the electricity demand decreased considerably as a result of power conservation and oil consumption did not substantially increase in 2011 as it had been relatively high in the previous hot summer. Towards the end of the year, however, oil consumption increased again because the impact of the shutdown of nuclear power plants spread to affect the entire country.

Monthly LNG consumption, on the other hand, grew by around $20 \%$ to $30 \%$ throughout the year. Yet, in the summer demand period, as natural gas power plants generally operate at high utilization rates, the scale of increase in LNG consumption was limited in summer 2011. Since October, as with oil consumption, there was some acceleration of growth as more nuclear reactors were taken offline.

Finally, Figure 9 depicts a breakdown of estimated volume of power generated in Japan by fuel type. ${ }^{24}$ The total 10 EPCOs' power generated volume in August (the peak season) declined from around $80 \mathrm{TWh} /$ month in 2010 to around $70 \mathrm{TWh} / \mathrm{month}$ in 2011. As power generated during the off-peak season remained at the same level as the previous year, differences between peak and off-peak season narrowed by $10 \mathrm{TWh} /$ month. As far as changes in the power generation portfolio are concerned, the share of power generated by nuclear power in the total supply volume had decreased gradually from $30 \%-40 \%$ in 2010 to less than $20 \%$ in July 2011 . The share of coal thermal plants, which were heavily damaged by the earthquake, declined from 2010 but had remained around 20\% throughout 2011.

\footnotetext{
24 These figures are author's estimates based on data of fuel consumption by EPCOs as no comprehensive statistics on power output by fuel are published in Japan.
} 
Table 4: Monthly fuel consumption for electric companies - 2010/2011 (MTOE)

\begin{tabular}{|c|c|c|c|c|c|c|c|c|c|c|c|}
\hline & & Mar & Apr & May & Jun & Jul & Aug & Sep & Oct & Nov & Dec \\
\hline \multirow[t]{2}{*}{ Fuel O } & 2010 & 0.41 & 0.32 & 0.27 & 0.40 & 0.69 & 0.83 & 0.76 & 0.26 & 0.50 & 0.45 \\
\hline & 2011 & 0.49 & 0.32 & 0.42 & 0.48 & 0.76 & 1.06 & 0.90 & 0.94 & 0.97 & 1.38 \\
\hline yoy & & $19 \%$ & $0 \%$ & $52 \%$ & $21 \%$ & $11 \%$ & $28 \%$ & $18 \%$ & $259 \%$ & $92 \%$ & $205 \%$ \\
\hline \multirow[t]{2}{*}{ Crude } & 2010 & 0.20 & 0.17 & 0.19 & 0.24 & 0.43 & 0.71 & 0.61 & 0.07 & 0.14 & 0.26 \\
\hline & 2011 & 0.55 & 0.35 & 0.43 & 0.45 & 0.52 & 0.75 & 0.69 & 0.97 & 1.02 & 1.24 \\
\hline yоy & & $180 \%$ & $113 \%$ & $122 \%$ & $88 \%$ & $20 \%$ & $6 \%$ & $13 \%$ & $1254 \%$ & $651 \%$ & $375 \%$ \\
\hline \multirow[t]{2}{*}{ LNG } & 2010 & 4.59 & 4.15 & 3.63 & 4.03 & 4.73 & 5.45 & 4.60 & 3.89 & 4.03 & 4.89 \\
\hline & 2011 & 4.97 & 4.45 & 4.69 & 5.24 & 5.84 & 6.25 & 5.66 & 5.08 & 5.32 & 6.42 \\
\hline yoy & & $8 \%$ & $7 \%$ & $29 \%$ & $30 \%$ & $23 \%$ & $15 \%$ & $23 \%$ & $31 \%$ & $32 \%$ & $31 \%$ \\
\hline \multirow[t]{2}{*}{ Coal } & 2010 & 2.33 & 1.89 & 1.96 & 2.22 & 2.57 & 2.76 & 2.54 & 2.29 & 2.23 & 2.54 \\
\hline & 2011 & 2.37 & 1.79 & 1.74 & 1.99 & 2.52 & 2.56 & 2.33 & 2.28 & 2.32 & 2.63 \\
\hline yoy & & $2 \%$ & $-5 \%$ & $-11 \%$ & $-11 \%$ & $-2 \%$ & $-7 \%$ & $-8 \%$ & $0 \%$ & $4 \%$ & $3 \%$ \\
\hline
\end{tabular}

Source: Statistics of Electricity, METI Web site

Japan has a significant level of thermal oil generation capacity. This is usually used only for peak load power supply, but its share in total supplies increased from $5 \%$ in 2010 to around $15 \%$ in the end of 2011. During the same period, the share of hydro power remained unchanged and the share of nuclear and thermal power changed from $35 \%$ to $10 \%$ and from $60 \%$ to $80 \%$, respectively.

\section{Figure 9: Estimated power generated in 2010 and 2011 (10 EPCOs)}
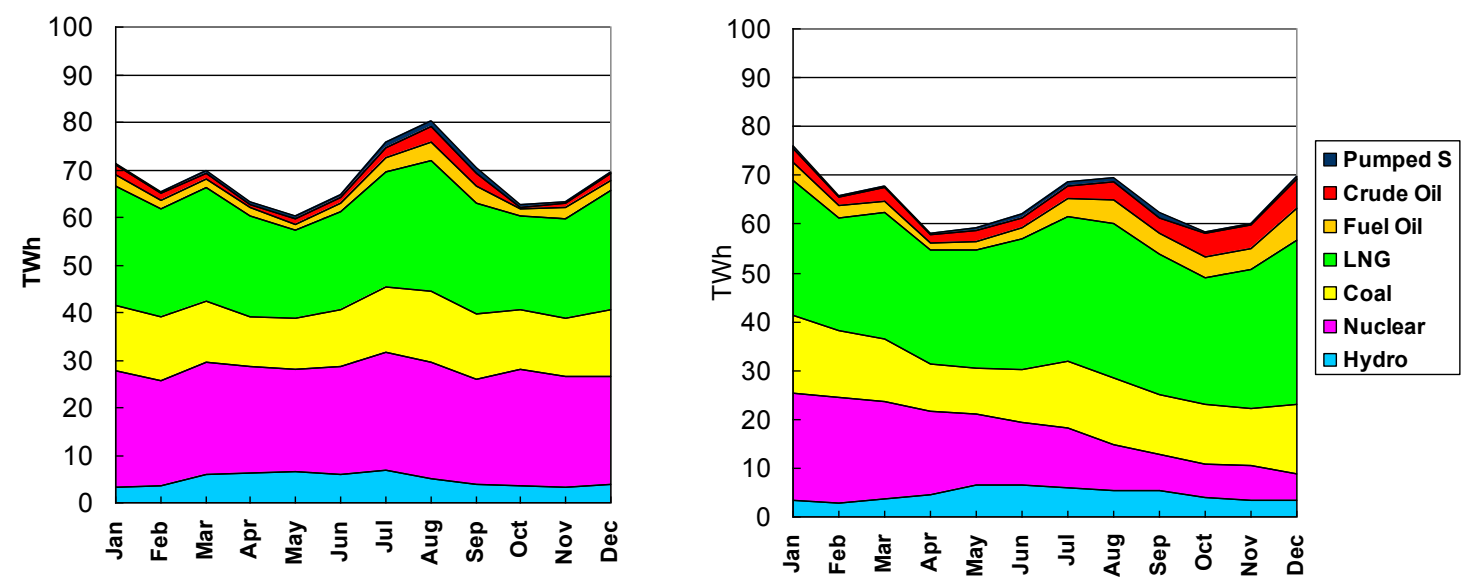

Note: As small power sources such as renewables, LPG and so on, are not included, these figures are estimates. Source: Authors' estimates based on data published by METI 


\subsubsection{LNG procurement and its impact on the international market}

As the effects of the earthquake were initially limited to east Japan, additional LNG supplies were available from other regions of Japan. ${ }^{25}$ Also swap transactions were made with other LNG buyers in Asia ${ }^{26}$. In April, spot procurements also began to grow. From May, however, as the government's policy on nuclear power became increasingly unsettled following the shutdown of Hamaoka NPS, Not only Tokyo and Tohoku but also other EPCOs had to increase LNG procurement volume by spot \& short-term contracts. For example, shortly after the disaster, Russia's prime minister, Vladimir Putin, directed that Russian supplies of LNG to Japan be increased, and Indonesia and Qatar arranged to increase supplies.

In 2011, consumption of LNG for power generation increased some $8 \mathrm{Mt}$ from the previous year. ${ }^{27} \mathrm{~A}$ combination of factors also made it somewhat easier to procure such additional LNG, including the increased flexibility of transactions, the availability of LNG with no predetermined destination, and the positive attitude of supplying countries anticipating new contracts to meet the incremental LNG demand for the future.

Table 5: Spot and short-term LNG contracts entered post-11 March

\begin{tabular}{|l|cc|}
\hline Export country & Importer & Volume \\
\hline $\begin{array}{l}\text { Qatar, Indonesia, Russia, } \\
\text { Australia, Others }\end{array}$ & Tohoku E & $0.8 \mathrm{Mt}$ \\
\hline Qatar & Chubu E & $3.2 \mathrm{Mt}$ \\
\hline $\begin{array}{l}\text { Qatar, Indonesia, Russia } \\
\text { Australia, Others }\end{array}$ & Kansai E & $0.8 \mathrm{Mt}$ \\
\hline $\begin{array}{l}\text { Qatar, Indonesia, Russia } \\
\text { Australia, Others }\end{array}$ & TEPCO & $6 \mathrm{Mt}$ \\
\hline Qatar & Kyusyu E & $0.1 \mathrm{Mt}$ \\
\hline
\end{tabular}

Note: The above table does not cover all spot and short-term transactions.

Source: Various sources

Measures were also taken within Japan to eliminate the various obstacles hindering procurement of fuel supplies. For example, large $210,000 \mathrm{~cm}^{3}$ Q-Flex and $260,000 \mathrm{~m}^{3}$ Q-Max carriers played an important role in transporting LNG under Qatari contracts as

\footnotetext{
25 For example, Kansai EPCO, Chubu EPCO, and Chugoku EPCO each made cargo swaps with TEPCO.

${ }^{26}$ Including 1.0-1.5 Mt swaps each month from March with KOGAS following the Korean government's announcement of its intention to provide emergency supplies of LNG to Japan. $2749.0 \mathrm{Mt}$ in 2011 and $41.0 \mathrm{Mt}$ in 2010. METI.
} 
the ability to accommodate these classes of carrier in Japan made it possible to receive increased supply volume under cargo-based contracts.

Additionally, procedures were streamlined following the earthquake to speed up the normally time-intensive port entry application process for first-time spot charters arriving in Japan.

As far as the impact on the international market is concerned, it was easily able to absorb increased procurement of around $1 \mathrm{Mt}$ per month due mainly to the adoption of more flexible Western-style business models made possible by the expanded supply capacity of Qatar, (which was planning to deliver supplies to the United States and Europe), the 'global gas glut' created by the expansion of shale gas output in the U.S. and the economic downturn in Europe. This is demonstrated by the fact that LNG spot prices were lower than Japanese long-term LNG contract prices throughout the period. Electric utilities gave priority to LNG spot procurements at prices below oil prices or prices under long-term contracts. In the initial stages at least, there appears to have been no significant disruption of the international LNG marketplace. Due to the unpredictable nature of government policy on nuclear power, however, the possibility of long-term growth in Japanese demand for LNG has led to prices under newly entered long-term contracts being set relatively high by historic standards. The impact of the over-estimates of growth in LNG that had been variously reported following the Fukushima incident has also been significant, and may possibly have deferred the conclusion of long-term contracts by other Asian countries as well as Japan.

\section{Figure 10: JCC and spot prices in 2011}

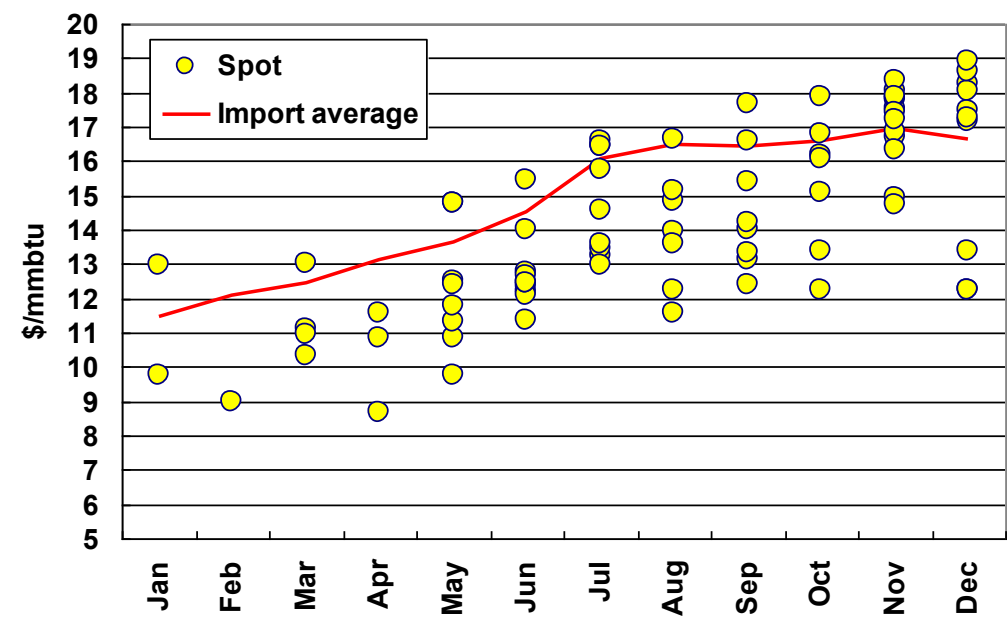

Source: Authors'estimate based on Trade Statistics, Japan Customs 


\subsection{Trends in the City Gas Market}

\subsubsection{Gas consumption up to 11 March}

During the period from FY1990 to FY2010, gas consumption in the City Gas sector showed strong growth, up to $4.0 \%$ on an annual basis, while GDP grew by only $0.9 \%$ /year. Electricity demand also grew strongly, though the rate was only $1.6 \%$. Consumption of oil and coal, meanwhile, declined. As shown in Table 6, final energy consumption has apparently shifted from coal and oil to gas and electricity. Even in FY 2010, however, gas's share of total stationary energy consumption was still just $14 \%$ (see Table 7). This is ascribed primarily to the slow pace of development of the gas supply infrastructure in Japan, which may indicate that considerable latent demand for natural gas yet remains.

\section{Figure 11: Trends in secondary energy and total stationary energy consumption} $(1990=100)$

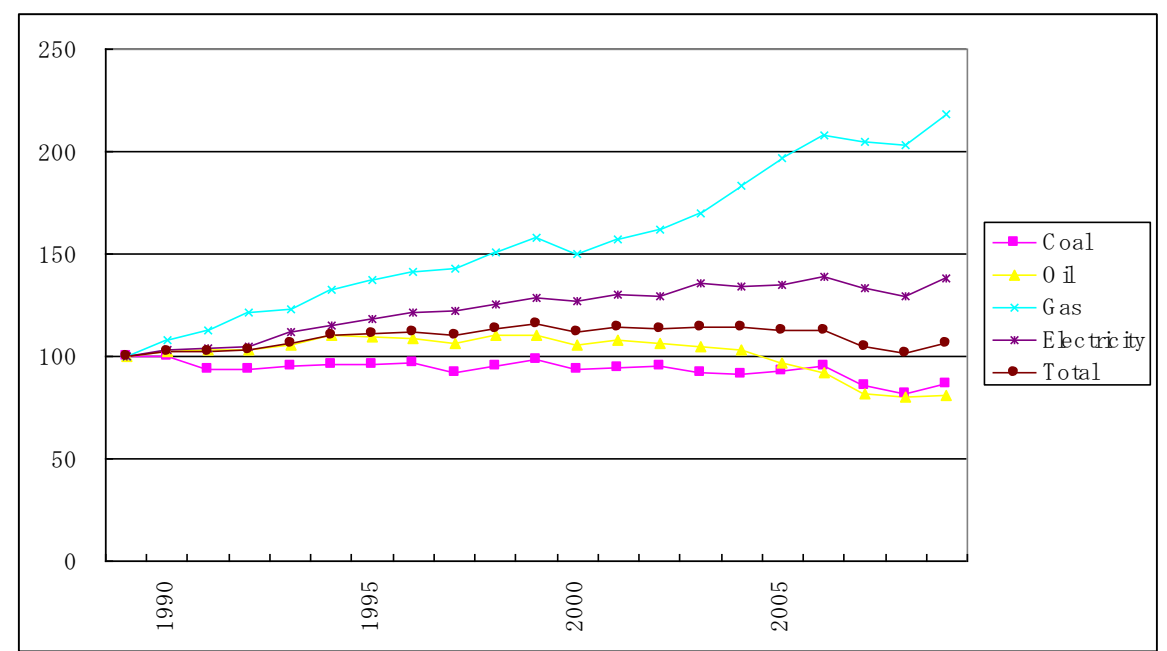

Source: 'EDMC Handbook of Energy \& Economic Statistics 2011' The Energy Conservation Center, Japan 
Table 6: Annual growth rate of GDP and energy consumption (\%)

\begin{tabular}{|c|c|c|c|c|c|}
\hline & & & $1990 / 2000$ & $2000 / 2010$ & $1990 / 2010$ \\
\hline \multicolumn{3}{|c|}{ GDP } & 1.1 & 0.6 & 0.9 \\
\hline \multicolumn{3}{|c|}{ Primary Energy } & 1.4 & -0.4 & 0.5 \\
\hline \multicolumn{3}{|c|}{ Final Energy } & 1.5 & -0.9 & 0.3 \\
\hline \multicolumn{3}{|c|}{ Stationary E } & 1.5 & -0.9 & 0.3 \\
\hline \multirow{7}{*}{$\begin{array}{c}\text { By } \\
\text { Fuel }\end{array}$} & & Coal & -0.1 & -1.3 & -0.7 \\
\hline & & Oil & 1.0 & -3.1 & -1.1 \\
\hline & & ectricity & 2.5 & 0.8 & 1.6 \\
\hline & \multirow{4}{*}{$\begin{array}{c}\text { By } \\
\text { Sector }\end{array}$} & Gas & 4.7 & 3.3 & 4.0 \\
\hline & & Residential & 2.0 & 0.3 & 1.2 \\
\hline & & Commercial & 5.2 & 2.0 & 3.6 \\
\hline & & Industrial & 7.8 & 6.2 & 7.0 \\
\hline
\end{tabular}

Source: 'EDMC Handbook of Energy \& Economic Statistics 2011' The Energy Conservation Center, Japan

Table 7:Share in stationary energy consumption (\%)

\begin{tabular}{|c|c|c|}
\hline & FY 1990 & FY 2010 \\
\hline Coal & 17.5 & 14.3 \\
\hline Oil & 47.6 & 36.2 \\
\hline Electricity & 26.4 & 34.4 \\
\hline Gas & 6.7 & 13.7 \\
\hline Others & 1.8 & 1.4 \\
\hline Total & 100.0 & 100.0 \\
\hline
\end{tabular}

Note: Figures for gas are sum of city gas and domestically produced natural gas. In FY 2010, the latter accounted for $3 \%$ of the gas total.

Source: 'EDMC Handbook of Energy \& Economic Statistics 2011' The Energy Conservation Center, Japan

A breakdown of city gas sales over the past 10 years (see Table 8) shows that, despite fluctuating year to year due to ambient temperature variations, sales in the residential sector have edged up by an annual average of just $0.3 \%$. This low rate is attributable to rising electrification (as exemplified by the spread of 'all electric homes'), which has offset growth in the number of households. Gas consumption in the commercial sector grew steadily in the first half of the 2000s. Being highly susceptible to economic trends, however, consumption fell markedly following the Lehman crisis. In the industrial sector, there was extremely strong growth in the first half of the 2000 s owing to a combination of factors, including the comparatively robust economy, increased price competitiveness relative to oil on account of rising oil prices, and environmental 
attractiveness due to its lower $\mathrm{CO}_{2}$ emissions. As in the commercial sector, however, industrial consumption was clearly affected by the economic downturn following the Lehman crisis. As a result, the share of gas in the residential and commercial sectors fell from $37.9 \%$ to $27.7 \%$ and from $16.2 \%$ to $13.4 \%$ respectively, while gas' share in the industrial sector surged from $37.4 \%$ to $50.0 \%$ during the past decade.

Although it is not readily apparent from macro-level trends in sales, price competitiveness of natural gas relative to electricity declined substantially following the sharp escalation of oil prices from 2004. Consequently, the adoption of cogeneration systems which had hitherto driven increases in gas consumption stagnated considerably. Yet, it should be noted that new developments that could potentially reverse this trend are emerging; for example, the shift to distributed power systems and the rise in electricity rates.

Table 8: Year-on-year changes in sales of city gas (all Japan, \%)

\begin{tabular}{|c|c|c|c|c|c|c|c|c|c|c|}
\hline FY & 2002 & 2003 & 2004 & 2005 & 2006 & 2007 & 2008 & 2009 & 2010 & $2011^{*}$ \\
\hline Residential & 3.4 & 0.3 & -2.5 & 4.9 & -1.6 & 1.1 & -2.3 & -0.2 & 1.7 & -2.0 \\
\hline Commercial & 5.9 & 1.9 & 6.4 & 3.8 & -2.2 & 3.3 & -3.7 & -3.0 & 2.7 & -10.3 \\
\hline Industrial & 12.9 & 9.1 & 10.4 & 11.3 & 11.3 & 10.3 & -5.0 & -3.1 & 5.5 & 3.5 \\
\hline Others & 9.6 & 2.4 & 9.3 & 6.7 & -3.5 & 6.0 & -2.6 & 1.2 & 8.3 & -10.5 \\
\hline Total & 8.0 & 4.3 & 5.3 & 7.7 & 4.0 & 6.3 & -3.9 & -1.9 & 4.3 & -1.2 \\
\hline
\end{tabular}

Note: * First half of FY2011

Source: The Japan Gas Association

\subsubsection{Impact of 11 March on city gas demand}

As shown in Table 9, which describes gas sales by region, double-digit declines have continued in the Tohoku region affected by the disasters, and the Kanto-Koshinetsu region was affected after 11 March 2011. In general, however, city gas penetration is typically low and consumption is also small outside the main urban areas of Japan. ${ }^{28}$ Consequently, while the earthquake caused interruptions to city gas service over a wide area, affecting six prefectures from Iwate to Kanagawa, the number of customers directly affected was a comparatively small $463,000 .^{29}$

In addition to the direct effects of the earthquake, city gas demand has also been indirectly affected by the subsequent moves to save power and energy and the economic downturn. The figures on gas sales in the first half of FY 2011, which includes the post-quake period, show that whereas residential sales declined $2 \%$ and

28 The three leading gas utilities (Tokyo Gas, Osaka Gas, and Toho Gas) together accounted for $70 \%$ of nationwide gas sales in FY 2010.

29 Following the Great Hanshin Earthquake in January 1995, 857,000 customers were affected by stoppages. 
commercial sales slumped $10.3 \%$, sales to industry rose $3.5 \%$. As a result, sales declined $1.2 \%$ overall. Breakdowns for the period are shown by month and region in Table 9.

One post-quake development has been the especially marked decline in sales to the commercial sector, particularly in the Tokyo Gas area (Table 10), where the government invoked an order restricting electricity use and promoting energy saving.

In the second half of FY 2011, while similar effects through energy saving were observed, higher utilization rates of cogeneration and self-generated power led to an in increase in gas sales particularly in the industrial sector. Particularly, in February 2012, gas sales in the sector surged by $18.3 \%$ in comparison with the previous year ${ }^{30}$ and during the period from April 2011 to February 2012, the growth rate was 5.3\%. Thus, total gas sales over the fiscal year as a whole are highly likely to increase by around $1 \%$ year on year.

Table 9: Year-on-year changes in city gas sales in 2011

\begin{tabular}{|c|c|c|c|c|c|c|c|c|c|c|c|c|c|}
\hline & Month & 1 & 2 & 3 & 4 & 5 & 6 & 7 & 8 & 9 & 10 & 11 & 12 \\
\hline \multirow{5}{*}{$\begin{array}{l}\text { By } \\
\text { Sector }\end{array}$} & Residential & 1.2 & 3.7 & 3.4 & -2.5 & -8.3 & 1.1 & -6.1 & -0.7 & 15.6 & 4.9 & -8.7 & -1.1 \\
\hline & Commercial & 1.4 & 1.8 & -1.7 & -8.4 & -10.9 & -6.7 & -10.1 & -13.0 & -10.7 & -6.7 & -9.5 & 1.2 \\
\hline & Industrial & 2.7 & -0.9 & -4.3 & 1.4 & 5.6 & 1.3 & 1.6 & 7.2 & 4.7 & 5.3 & -0.7 & 6.0 \\
\hline & Others & 3.0 & 5.4 & 1.3 & -7.1 & -9.5 & -6.3 & -9.5 & -13.1 & -13.0 & -6.4 & -12.0 & 0.5 \\
\hline & Total & 2.0 & 1.7 & -0.9 & -1.7 & -2.0 & -0.3 & -2.8 & -0.4 & 1.2 & 2.4 & -4.6 & 2.8 \\
\hline \multirow{8}{*}{$\begin{array}{l}\text { By } \\
\text { Regio } \\
\text { n }\end{array}$} & Hokkaido & -0.5 & -4.5 & -3.9 & -4.5 & -1.5 & 0.2 & -4.0 & -4.8 & -1.0 & 2.7 & -5.0 & 10.2 \\
\hline & Tohoku & 5.5 & 3.9 & -3.0 & -12.6 & -26.1 & $\begin{array}{c}-25 . \\
9\end{array}$ & -22.3 & -22.2 & -15.2 & -6.4 & -9.7 & -1.5 \\
\hline & $\begin{array}{l}\text { Kanto/ } \\
\text { Koshinetsu }\end{array}$ & -0.8 & -1.1 & -3.5 & -2.7 & -3.5 & -0.4 & -3.4 & -0.2 & 3.2 & 1.7 & -6.4 & 5.6 \\
\hline & $\begin{array}{l}\text { Chubu } \\
\text { /Hokuriku }\end{array}$ & 7.0 & 6.2 & 1.8 & -7.4 & -2.5 & -2.5 & -4.4 & 0.1 & -1.5 & 3.9 & -1.9 & 3.2 \\
\hline & Kinki & 4.6 & 3.8 & 2.4 & 2.4 & 1.8 & 2.3 & -0.1 & 0.8 & 0.2 & 3.4 & -2.7 & -1.7 \\
\hline & Chugoku & 2.6 & 2.9 & -0.2 & 1.6 & 4.2 & 4.2 & 0.6 & -0.6 & 3.9 & 7.7 & -0.3 & -0.7 \\
\hline & Shikoku & 7.2 & 10.6 & 8.1 & 5.5 & 3.8 & -0.2 & 7.5 & 2.8 & -1.3 & 1.6 & 0.4 & -0.8 \\
\hline & $\begin{array}{l}\text { Kyushu } \\
\text { /Okinawa }\end{array}$ & 5.7 & 9.3 & 3.0 & 2.4 & 0.6 & -0.3 & -2.2 & -1.8 & -2.1 & -0.1 & -4.4 & -3.2 \\
\hline
\end{tabular}

Source: The Japan Gas Association

\footnotetext{
30 The growth rate of Tokyo Gas was 37.5\%, Osaka Gas; $11.4 \%$, Toho Gas; $8.2 \%$ in February 2012. It was reported that the reason for the growth was mainly due to increase in utilization rate of customers' facilities. The Japan Gas Association, 27 March 2012.
} 
Table 10: Year-on-year changes in city gas sales of two leading utilities 2011 (\%)

\begin{tabular}{|c|c|c|c|c|c|c|c|c|c|c|c|c|c|}
\hline & month & 1 & 2 & 3 & 4 & 5 & 6 & 7 & 8 & 9 & 10 & 11 & 12 \\
\hline $\mathrm{T}$ & Residential & -1.1 & 4.2 & 3.2 & -5.5 & -12.7 & 4.4 & -8.1 & 1.7 & 20.0 & 3.7 & -10.9 & 1.7 \\
\hline $\mathrm{O}$ & Commercial & 0.2 & 1.5 & -2.0 & -12.4 & -16.2 & -8.8 & -13.8 & -16.0 & -10.9 & -5.9 & -11.1 & 0.8 \\
\hline K & Industrial & -6.0 & -14.3 & -12.0 & 4.3 & 8.0 & 1.4 & 4.8 & 13.3 & 11.7 & 2.3 & -4.0 & 9.9 \\
\hline Y & Others & 0.3 & 3.7 & -3.8 & -13.5 & -18.7 & -12.3 & -18.3 & -17.8 & -14.2 & -4.8 & -14.6 & -0.7 \\
\hline $\mathrm{O}$ & Total & -2.7 & -3.3 & -4.5 & -3.1 & -4.9 & -0.6 & -3.8 & 0.7 & 4.7 & 0.5 & -7.8 & 5.0 \\
\hline $\mathrm{O}$ & Residential & 3.7 & 2.7 & 3.6 & 1.5 & -3.8 & 0.7 & -5.3 & -0.6 & 16.9 & 6.9 & -7.5 & -5.2 \\
\hline S & Commercial & 3.4 & 5.2 & 1.9 & 0.2 & -6.7 & 1.8 & -4.3 & -9.3 & -10.5 & -8.6 & -9.7 & -2.4 \\
\hline A & Industrial & 5.7 & 4.0 & 1.1 & 3.3 & 7.5 & 2.5 & 2.6 & 6.4 & 2.1 & 7.1 & 2.1 & 0.9 \\
\hline K & Others & 4.2 & 6.0 & 4.3 & 5.4 & -2.6 & 7.3 & -0.1 & -6.8 & -8.1 & -5.3 & -8.6 & -2.2 \\
\hline A & Total & 4.5 & 3.8 & 2.3 & 2.5 & 1.7 & 2.3 & 0.0 & 1.0 & 0.3 & 3.5 & -2.5 & -1.6 \\
\hline
\end{tabular}

Source: The Japan Gas Association

\subsection{Debate on Japan's Long-Term Energy Policy}

In this section, we describe the main changes in energy supply and demand and trends in the energy market since 11 March 2011 in order to establish the necessary premises for estimating long-term LNG demand.

\subsubsection{Slowing of economic growth}

Negative impacts by the earthquake on public and economic activity include the following:

- Paralysis of elements of the physical distribution system, including expressway and rail networks in eastern Japan

- Plant stoppages in affected regions and disruption of manufacturing supply chains (affecting especially the automobile industry)

- The very significant impact of power shortages due to rolling blackouts and the imposition of restrictions on power use

- The impact of radioactive contamination on agricultural and marine produce

These impacts caused the economy to deteriorate and, as shown in Table 11, real GDP plunged into negative growth year on year in the first quarter of FY2011. In the second quarter, the restoration at last of some supply chains that had been disrupted by the earthquake and nascent reconstruction demand fuelled a return to positive growth. 
On the other hand, the Yen's rapid appreciation propelled by Europe's fiscal and financial difficulties and the impact of severe flooding in Thailand on many Japanese firms' production operations have put a brake on Japan's export industries in particular. In the short term, while the positive impact of reconstruction demand has been offset by the deterioration of the external environment caused by the global economic downturn, the Japanese economy is expected to grow by around 1.7\% in FY 2012.

Yet, the outlook in the medium to longer term depends to a large extent on how the electric power question is addressed, and especially on when Japan's existing nuclear power stations are restarted and what long-term shape the electricity supply structure takes. Many of the manufacturers that have sustained Japan's economic growth to date are now beginning to consider transplanting production abroad further. If nuclear power does not come back online, and a large portion of the electricity supply is substituted by thermal power generation, electricity rates will inevitability be increased due to high fuel costs. This would lead to a possible further acceleration of Japan's de-industrialization.

Table 11: Trend in real GDP (\%)

\begin{tabular}{|c|c|c|c|c|c|c|c|c|}
\hline \multirow[t]{2}{*}{ FY } & \multirow[t]{2}{*}{2009} & \multirow[t]{2}{*}{2010} & \multicolumn{4}{|c|}{2011} & & \multirow[t]{2}{*}{2012} \\
\hline & & & I & II & III & IV & & \\
\hline $\begin{array}{l}\text { Growth } \\
\text { rate }\end{array}$ & -1.9 & 3.1 & -0.3 & 1.7 & -0.2 & $0.4 *$ & $-0.3 *$ & $1.7 *$ \\
\hline
\end{tabular}

Note: * Outlook

Source: 'Short-term Forecast'Japan Center for Economic Research, $9^{\text {th }}$ March 2012

\subsubsection{Stagnation of energy consumption}

The events of 11 March had a variety of effects on energy consumption.

- From a macro-perspective, the economic downturn caused energy consumption to stagnate nationwide.

- In the affected regions, energy consumption dropped sharply as energy supply facilities, such as oil refineries and power generation plants, were rendered inoperative and the infrastructure of everyday life and industrial activity was destroyed.

- The shutdown of nuclear power stations led to a sharp rise in consumption of fossil fuels in the power generation sector.

- In addition to cuts in consumption enforced by rolling power cuts and restrictions on electricity use, the public and private sectors together ran campaigns to 
encourage voluntary conservation, resulting in reduced energy (and especially electricity) consumption nationwide.

Viewed by energy source, we can identify the following principal developments.

- Although several coal power plants in eastern Japan were damaged by the earthquake, the load factor of those still operational increased substantially as they replaced lost output from nuclear power. As a result, the decline in coal fired power generation from the previous year was only around $0.9 \%$ on a primary energy basis.

- As for LNG, consumption in the city gas sector is expected to remain level year on year, as noted above. In the electricity sector, however, the large increase in the load factor of LNG power plants to replace lost nuclear power output is expected to cause consumption to surge by 19\% in FY2011 from a year earlier overall.

- Outside of the power sector the downward trend in oil consumption is expected to continue in FY 2011 on account of energy-saving measures and the economic downturn. However, increased use of thermal power plants and self-generation fuelled by oil are projected to result in an overall increase of around $1.7 \%$.

Table 12: Year-on-year change in primary energy consumption

\begin{tabular}{|c|c|c|c|}
\hline FY & 2009 & 2010 & 2011 (estimate) \\
\hline Coal & -7.8 & 11.4 & -0.9 \\
\hline Oil & -6.1 & 1.2 & 1.7 \\
\hline Natural Gas & -2.6 & 5.8 & 19.0 \\
\hline Hydro & 1.0 & 2.5 & -2.8 \\
\hline Nuclear & 8.4 & 3.0 & -64.5 \\
\hline Other & -2.9 & 3.7 & -1.2 \\
\hline Primary Energy Total & -4.0 & 4.6 & -3.7 \\
\hline
\end{tabular}

Source: Short term energy outlook, Institute of Energy Economic, Japan, $22^{\text {nd }}$ Dec. 2011. 
Table 13: Year-on-year change in final energy consumption

\begin{tabular}{|c|c|c|c|c|}
\hline \multicolumn{2}{|c|}{ FY } & 2009 & 2010 & 2011 (Estimate) \\
\hline \multirow{4}{*}{$\begin{array}{l}\text { By } \\
\text { Sector }\end{array}$} & Industrial & -3.2 & 3.7 & -3.1 \\
\hline & Commercial & -2.7 & 5.4 & -7.4 \\
\hline & Residential & -0.8 & 5.6 & -5.2 \\
\hline & Transportation & -1.7 & 0.9 & -2.8 \\
\hline \multirow{6}{*}{$\begin{array}{l}\text { By } \\
\text { Source }\end{array}$} & Coal & -4.6 & 5.6 & -3.3 \\
\hline & Oil & -1.7 & 0.7 & -4.4 \\
\hline & City Gas & -0.6 & 7.2 & 0.9 \\
\hline & Electricity & -3.4 & 7.2 & -5.1 \\
\hline & Other & -7.8 & 7.2 & -1.4 \\
\hline & Total & -2.4 & 3.5 & -3.9 \\
\hline
\end{tabular}

Source: Short term energy outlook, Institute of Energy Economic, Japan, $22^{\text {nd }}$ Dec. 2011

\subsubsection{Comprehensive energy policy}

Overview of energy policy pre-11 March: We begin by briefly summarizing energy policy prior to 11 March. To assist the pursuit of national energy policy from a long-term perspective, Japan enacted a 'Basic Act on Energy Policy' in June 2002 that lays down the basic principles for development of policy. Pursuant to this act, the government adopted a 'Basic Energy Plan' to promote comprehensive measures. This basic plan is required to be revised at least once every three years.

The last basic plan before 11 March was adopted in June 2010, and its main points are summarized as follows. Seven principal guides to development of energy policy are identified: ensuring energy security, enhancing action against global warming, attaining economic growth, ensuring safety, ensuring efficiency through the use of market mechanisms, reforming the structure of the energy industry, and building mutual understanding with the public.

The goals adopted for attainment by 2030 were as follows:

- A doubling of energy self-sufficiency (from $18 \%$ when the plan was adopted) and the 'self-exploitation ratio ${ }^{31}$, for fossil fuels (from 26\%) and attainment of an independent energy ratio $^{32}$ of $70 \%$ (from $38 \%$ ) in order to enhance energy security.

\footnotetext{
31 The ratio of fossil fuels in which Japanese companies have rights and interests.

32 The ratio of indigenously produced energy (including nuclear power) in domestic primary energy supply.
} 
- An increase in the proportion of electricity produced from zero emission sources (nuclear power and renewables) to at least 50\% in 2020 and $70 \%$ in 2030 (from $34 \%$ when the plan was adopted).

- A halving in $\mathrm{CO}_{2}$ emissions from residential energy consumption.

- Enhancement of world-best energy efficiency in the industrial sector.

- Acquisition of top market shares by Japanese firms in the international markets for energy-related products and systems in which Japan is advantageously placed and market growth is expected.

By achieving the above five goals, energy-derived $\mathrm{CO}_{2}$ emissions were to be cut by $30 \%$ or more from their 1990 level by 2030 .

The points to note regarding long-term energy supply and demand were, as illustrated in Figures 12 and 13:

- Attainment of a significant downward trend in energy consumption.

- Lowering of the fossil fuel ratio as a proportion of primary energy.

- Further promotion of nuclear power to account for around 50\% of total power generated in 2030 .

- Enhanced promotion of renewables to around $40 \%$ of installed capacity and $20 \%$ of total power generated in 2030 .

Figure 12: Long term outlook for primary energy supply (formulated prior to 11 March)

Primary energy supply for 2030

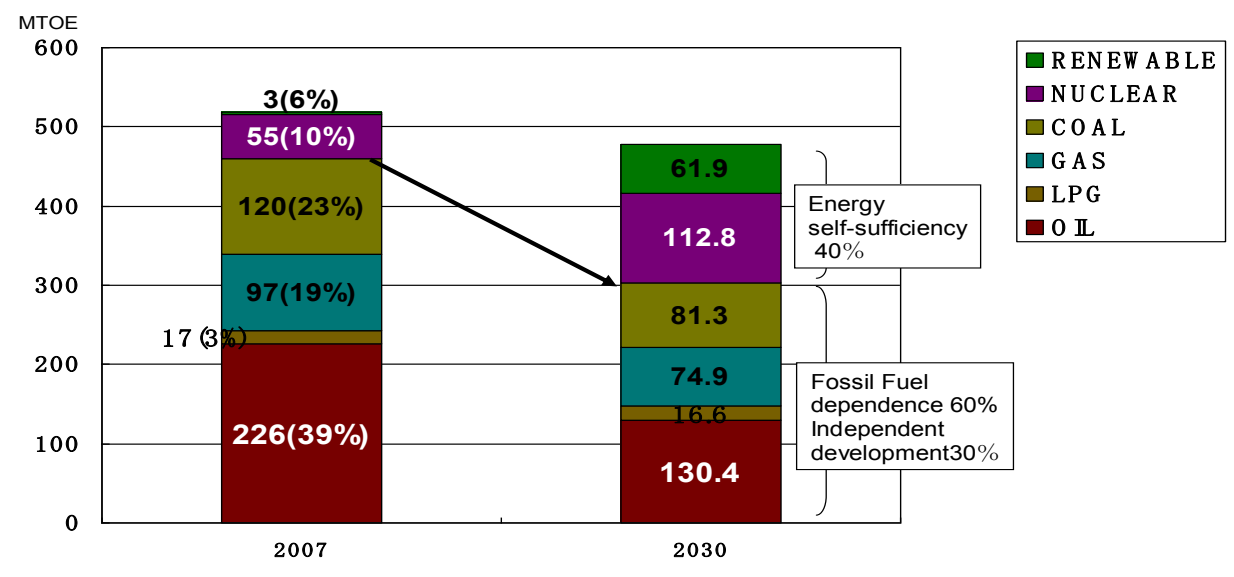

Renewable energy --- Implementation of feed in tariff system

Nuclear power --- Building additional 14 plants, facility utilization rate $90 \%$ 
Figure 13: Long term outlook for power supply (formulated prior to 11 March)
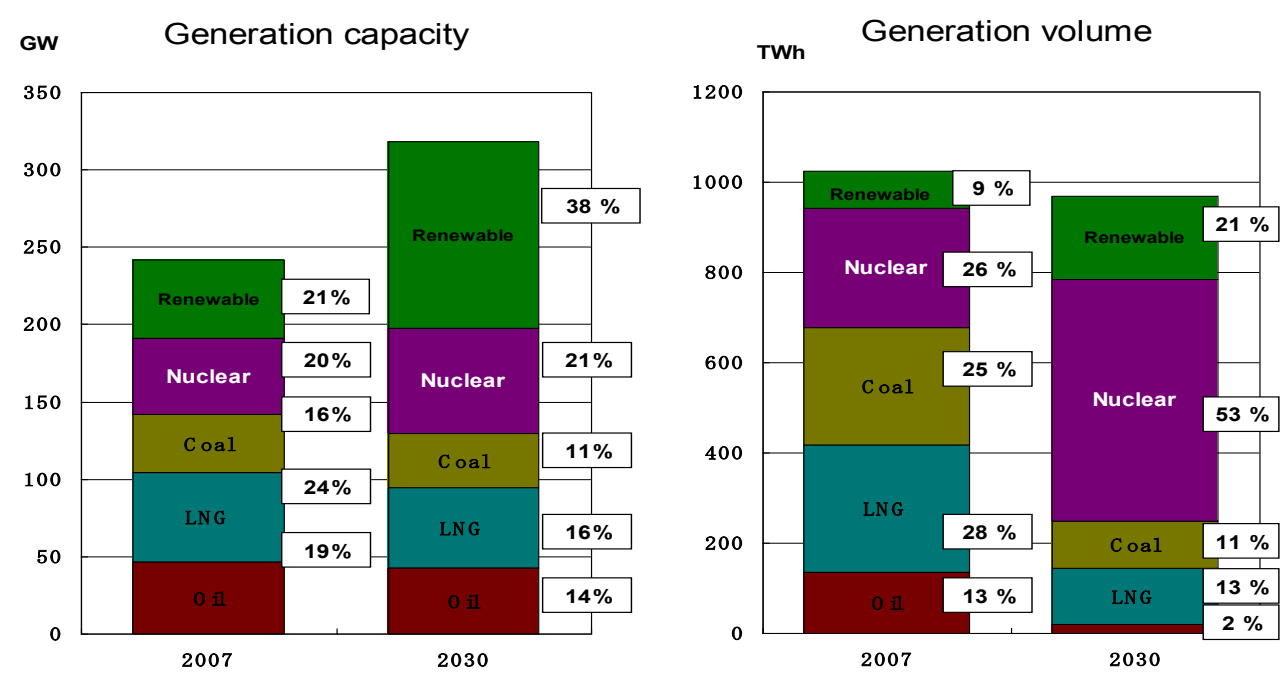

Source: 'Energy structure 2030, Long Term Energy Policy'June 2010. METI

Framework for determination of energy policy post-11 March: The Fukushima crisis has forced a reconsideration of the energy policy and, while the debate still rages on its exact form, the new post-quake long-term energy policy will be formulated within the following framework.

- While long-term energy policy used to be based on input from experts on METI's Advisory Committee for Energy and various related deliberative councils, policy itself was designed mainly by the bureaucrats of METI. One of the guiding principles of government advocated by the present Democratic Party administration, which replaced the Liberal Democratic Party in power, is the leadership of government by politicians and reduced dependence on bureaucrats and the review of energy policy is taking the same course. Specifically, the Energy and Environment Council established under the National Strategy Council is positioned as the heart of the policy debate ${ }^{33}$, which comes under the direct control of the prime minister. The council is scheduled to formulate a set of basic principles on energy policy called the 'Innovative Strategy for Energy and the Environment' by amalgamating various policies discussed in the Advisory Committee for Natural Resources and Energy, the Central Environment Council, the Japan Atomic Energy Commission, and other pre-existing organizations.

- The Energy and Environment Council is to put forward policy options in the summer of 2012. Further to public discussion of these options, it will then present an outline strategy later in the summer. ${ }^{34}$

${ }^{33}$ Mr. Fujimura, Chief Cabinet Secretary, at a press conference on 3rd Oct.2011

34 Energy and Environment Council, 'Basic Policy (Draft): Toward the Presentation of Options for an Energy and Environment Strategy' $21^{\text {st }}$ December 2011, http://www.npu.go.jp/policy/policy09/archive01_05.html\#haifu 
- It should therefore be noted that the details outlined in the following sub-section are not firm and remain under discussion.

Direction of energy and environmental policy post-11 March: Regarding the position on global warming, which represents a constraint on energy supply and demand, the mid-range target will be set based on the long term target of achieving an $80 \%$ reduction by $2050 .{ }^{35}$

Within the long-term framework, future energy policy is to be formulated placing priority on 'ensuring public safety' and emphasizing 'sustainability and public trust', 'demand-side measures', 'consumers, ordinary citizens, and communities', 'sustaining national resources and contributing to the international community', and 'utilization of diverse power and energy sources'.

The basic direction of development of the energy mix is laid out as follows: ${ }^{36}$

- Strengthening of energy and electricity conservation including the reshaping of user behaviour and reform of the social infrastructure.

- Accelerated development and use of renewables to the maximum possible extent.

- Effective utilization of fossil fuels (i.e., environmentally friendly use of fossil fuels), including a shift to greater use of natural gas, while giving maximum consideration to the impact on the environment.

- Reduced dependency on nuclear power wherever possible.

Other important measures reforming the demand-side structure, changing patterns of demand by limiting peak load, pursuing further action in the commercial and residential sectors where potential for energy savings are considerable, and optimized management of demand according to user characteristics, are also focused on.

As regards supply-side reforms, on the other hand, the Council recommends reducing dependence on large-scale centralized power sources by developing next-generation distributed generation systems tapping into various power resources (renewables, cogeneration, and self-generation). It also identifies the need to strengthen and broaden transmission and distribution networks and ensure neutrality in the transmission sector in order to develop such innovative supply systems.

35 The Central Environment Council. 'The Fourth Basic Environment Plan' http://www.env.go.jp/press/press.php?serial=15169

36 Fundamental Issues Subcommittee of the Advisory Committee on Energy and Natural Resources, 'Major Discussion Points Toward the Establishment of a New “Basic Energy Plan for Japan”, ,20

December 2011, http://www.meti.go.jp/english/press/2011/1220_05.html 
Developments of discussions on energy policy in the local governments: Another new trend in the energy policy arena is the emergence of strong interest in policy at the local government level. In the past, energy policy was considered primarily a bureaucratically led concern of the central government, with local governments either just accepting or being uninterested in such issues, and practical discussions on energy policy in the local governments were limited. Since the Fukushima crisis, however, local governments have been prompted by a variety of motives to begin to develop their own independent courses of action.

The most prominent development has been the emergence of strong demands for direct authority over the administration of nuclear power and direct involvement in nuclear power policy, prompted by the first-hand experience of the damage that can be caused over a wide area by an accident at a nuclear power station and the serious electricity shortages that have occurred in Tokyo and other major urban areas. The city assembly of Makinohara ${ }^{37}$ in Shizuoka Prefecture, for example, passed a resolution to permanently close down Hamaoka NPS, and the governor of Shizuoka Prefecture has firmly expressed the view that any decision on when or whether to recommence operations at the plant should be for the prefecture to decide. Tokyo and Osaka City, meanwhile, argue that as they have heavy concentrations of electricity consumers and are also large shareholders in certain of the EPCOs that have nuclear power stations, ${ }^{38}$ they should have the right to select their own power sources, leading them to explore new forms of involvement in central government-led policy on electric power.

Concerns that nuclear power policy may be at an impasse have also led the urban giants of Tokyo and Osaka to begin considering plans to build their own natural gas power plants in order to cope with the electricity shortages that are expected to consequently arise. ${ }^{39}$ Changes are also afoot in the provinces, where their visions to invite megawatt-scale solar power plants to assist the transition to a low-carbon society had been seriously hampered by the EPCOs' focus on developing nuclear power. ${ }^{40}$ Now, though, the nuclear impasse has increased the feasibility of pursuing an independent policy targeting regional economic revitalization leveraging the deployment of renewable energies and a shift to greater use of distributed generation systems. $^{41}$

37 Hamaoka NPS is located in the city of Omaezaki, and Makinohara is its neighbour to the northeast.

38 Shares in Kansai EPCO, for example, are owned by Osaka (9\%), Kobe (3\%), and Kyoto (0.45\%). Osaka's new mayor, Toru Hashimoto, made a campaign promise of pursuing a nuclear exit strategy.

39 For example, Tokyo has announced plans to build a 1,000MW-class natural gas power plant. The Union of Kansai Governments intends to consider construction of a similarly sized natural gas power plant as well.

40 Given the emphasis on nuclear power, hurdles including the bidding system for independent power producers (IPPs) and network access (instability as power sources) meant that electric utilities were reluctant to consider municipalities that put themselves forward as sites for renewable energy projects.

41 Taking 'local production for local consumption' as their watchword, projects are being developed across the country to develop geothermal systems, megawatt-scale solar power plants, tidal power generation systems and small-scale hydropower installations. 
At the meeting of the National Governors' Association convened in November 2011, national issues that formerly tended to be avoided, such as the tax system and energy policy, were actively addressed, and the association recommended that its members put forward their own individual visions of energy policy. This trend has coincided with moves toward decentralization brought to prominence by Osaka's 'metropolis' vision, and many local governments have begun to actively adopt their own long-term energy policies and targets. $^{42}$

\subsubsection{Changing public opinion on nuclear power and electricity market reform}

Since the Fukushima crisis, questions on nuclear power and power supply have become the subject of enormous public interest.

Trends in public opinion on nuclear power The Fukushima crisis continues to exert an enormous influence on the Japanese public in a variety of forms. Public interest in a range of issues has heightened remarkably, ranging across subjects including interests in Fukushima I itself, such as the immediate failure to contain the situation at Units 1-4 and the future lengthy process of decommissioning (expected to take at least 40 years); life in evacuation shelters for nearby residents; concerns about the impact on human health of radioactivity dispersed over a wide area; the problem of decontamination; the response regarding compensation for contamination and damage caused by harmful rumours; power saving and energy conservation campaigns prompted by electricity shortages; the resulting effect on people's lives and industrial activity; and the future shape of the electricity industry, and so on. The transformation of public opinion toward nuclear power was an inevitable consequence of the crisis. Needless to say, this change in opinion has been mirrored in the basic principles on energy policy outlined above in that emphasis is now placed on reducing dependence on nuclear power.

42 The Tokyo Metropolitan Government places an emphasis on energy policy in its 'Tokyo 2020' long-term plan, and has announced its intention to generate electricity as far as possible within the metropolitan area itself, rather than depending on the provinces for its energy supplies (Nihon Keizai Shimbun, $23^{\text {rd }}$ December 2011). Kanagawa Prefecture plans to increase renewables' share of electricity consumed in the prefecture to at least $20 \%$ by 2020 (Nihon Keizai Shimbun, $13^{\text {th }}$ September 2011), while the Union of Kansai Governments has agreed to deliberation of regional energy strategy by an energy panel (Nihon Keizai Shimbun, $22^{\text {nd }}$ December 2011). Okayama Prefecture is to incorporate plans for construction of a megawatt-scale solar power plant in its medium/long-term plan (Nihon Keizai Shimbun, $15^{\text {th }}$ December 2011), and Saitama Prefecture has set targets for installations of photovoltaic systems in its 'Five-year Plan' emphasizing the promotion of use of renewables (Nihon Keizai Shimbun, $27^{\text {th }}$ October 2011). 
Table 14: Change in public opinion on nuclear power (\%)

\begin{tabular}{|c|c|c|c|c|}
\hline Date of Survey & $2005.12\left({ }^{*} 1\right)$ & $2009.10(* 1)$ & $2011.06(* 2)$ & $2011.10(* 2)$ \\
\hline Expand & 55.1 & 59.6 & 3.0 & 2.1 \\
\hline Maintain status quo & 20.2 & 18.8 & 24.4 & 23.2 \\
\hline Reduce and decommission & 17.0 & 16.2 & 66.1 & 66.6 \\
\hline Don't know & 7.7 & 5.4 & 6.5 & 8.2 \\
\hline
\end{tabular}

Note: *1 Published by the Public Relations Department of the Cabinet Office.

\begin{tabular}{|l|c|c|}
\hline & December 2005 & October 2009 \\
\hline Sample & $\begin{array}{c}3,000 \text { individuals nationwide aged } \\
20 \text { and over }\end{array}$ & $\begin{array}{c}3,000 \text { individuals nationwide aged } \\
20 \text { and over }\end{array}$ \\
\hline Response rate & 1,712 individuals (57.1\%) & 1,850 individuals $(61.7 \%)$ \\
\hline Survey method & \multicolumn{2}{|c|}{ Interviews administered face to face } \\
\hline
\end{tabular}

Note: *2. NHK Broadcasting Culture Research Institute.

\begin{tabular}{|l|c|c|}
\hline & June 2011 & October 2011 \\
\hline Sample & $\begin{array}{c}2,652 \text { individuals nationwide aged } \\
20 \text { and over }\end{array}$ & $\begin{array}{c}2,620 \text { individuals nationwide aged } \\
\text { Response rate }\end{array}$ \\
\hline Survey method & \multicolumn{2}{|c|}{ Random digit dialled (RDD) tracking survey } \\
\hline
\end{tabular}

\subsubsection{Debate on deregulation of the electricity market}

The Fukushima crisis has also rekindled the debate on deregulation of Japan's electricity market, the state of which is briefly described as follows.

- Deregulation of the electricity market began with the revision of the Electricity Business Act in 1995, following which new entries to the electricity business, including the entry of power producers and suppliers (PPS) to the retail market were progressively allowed. In 2005, around 65\% of the retail market (serving $50 \mathrm{~kW}$ users and above) had been deregulated.

- In 2007, plans to extend deregulation to include even ordinary residential users were shelved and introducing the unbundling of the power industry disappeared from the agenda. Thus has the situation remained, and new entrants have grown to account for only around $2-3 \%$ of total demand in the electricity market as a whole. $^{43}$

- Although the exchange for wholesale electricity trading was established, the volume of spot transactions is still extremely low; only $0.53 \%$ of the entire demand in FY 2010. ${ }^{44}$

\footnotetext{
${ }^{43}$ METI, 'Major Issues for Discussion by the Task Force on the Reform of Electric Power Systems', 27 December 2011., http://www.meti.go.jp/english/press/2011/1227_02.html

44 Takahashi, Hiroshi, 'Market Liberalization of Electric Utilities', Nihon Keizai Shimbun, 21 October
} 
Thus while the electricity market has partially been liberalized, the pre-existing electric utilities remain in practice virtual monopolies.

Since the Fukushima crisis, however, the myth of 'absolutely safe' nuclear power has crumbled and rolling blackouts and curbs on power use by large business users have totally destroyed the argument made by opponents of deregulation that end-to-end integration from generation to distribution ensured supply stability.

Moving away from the traditional dependence on large power sources (primarily nuclear) and integrated operation system from generation to distribution, broad debates are thus now conducted to reform the electricity structure by shifting toward use of distributed generation sources powered by a variety of resources, development of smart grids to effectively reduce and control demand, and the establishment of neutrality in the transmission sector by splitting it off from supply chain in order to allow market mechanisms to function. Electricity reforms of this kind may also be needed to combat global warming if, as looks increasingly likely, Japan loses nuclear power as a central prop of its zero emission energy policy and so has to accelerate deployment of renewables.

With the basic policy for a comprehensive long-term energy strategy yet to be finalized, the debate on reform of the electricity industry remains fluid. ${ }^{45}$ Suffice to note, however, that there has emerged the possibility of a major change in direction toward development of such a new electricity structure in the process of how TEPCO - in other words, electricity supply in the Kanto region — should be rebuilt. As the utility comes to grips with its many problems, including the clean-up at Fukushima, compensation for radioactive contamination and the rising cost of fuel procurements, restructuring of the company is now being pushed by the government as a model for nationwide electricity reform in its scheme to bail out (in effect nationalize temporarily) TEPCO, which runs a high risk of becoming insolvent. ${ }^{46}$ Although TEPCO is expressing opposition to this, the question of whether the 'Comprehensive Special Business Plan' being formulated by TEPCO and the Nuclear Damage Liability Facilitation Fund will incorporate such a model is being watched with interest.

\subsubsection{Natural gas}

As we have observed, Japan's new energy policy is likely to move toward reducing dependence on nuclear power and promoting renewables and clean use of fossil fuels.

${ }^{46}$ Jiji Press, 7 January 2012. 
However, expanded full-scale use of coal depends upon the development of technologies such as carbon capture and storage (CCS). Moreover, renewables can not take the place of nuclear power due to the constraints on supply capacity and supply intermittency. The feasible solution to the energy supply problem is therefore to expand use of natural gas, which produces relatively low $\mathrm{CO}_{2}$ emissions.

The main factors governing growth in demand for natural gas are as follows:

- Increased load factor of existing gas power plants as it replaces nuclear power.

- Expanded construction of new large gas power plants to replace nuclear power.

- Increased use of cogeneration, distributed generation, and self-generation powered by natural gas in the industrial and commercial sectors.

- Increased use of fuel cell and other cogeneration technologies powered by natural gas in the residential sector.

- Improvement in the price competitiveness of city gas due to the strong likelihood of electricity rates being driven up by higher fuel procurement costs.

- Stagnation or discontinuation of moves by the EPCOs to promote all-electric homes. $^{47}$

However, this will require action to develop the natural gas supply infrastructure and lower LNG procurement costs, both of which have been long-standing factors hindering the expansion of supply of natural gas in Japan. There are thus emerging signs of these challenges being addressed on the policy front. ${ }^{48}$

\subsubsection{Energy conservation}

If the slump in nuclear power output continues in the medium to longer term, even more vigorous energy conservation than hitherto offers the Japan public an extremely effective and important means of cutting costs as well as protecting the environment and ensuring energy security. The series of events since 11 March may be aptly described as something of a grand social experiment, and we pick out some of the noteworthy developments that have occurred during this time.

47 Although utilities including TEPCO have already discontinued such moves, it is generally considered that reduced nuclear output will push up the nighttime cost of electricity and make all-electric homes financially less attractive.

48 For example, discussions in the Fundamental Issues Sub-Committee, Advisory Committee on Energy and Natural Resources and its investigative commissions. 
Joint public/private power-saving campaigns: On 13 May, METI announced a package of electricity supply and demand measures ('Electricity Supply-Demand Measures in Summer Time') to cope with the immediate electricity shortages. Following the principles outlined therein, the Agency for Natural Resources and Energy worked with other relevant ministries and agencies to produce a power-saving campaign targeted at businesses and ordinary households. Although energy conservation has always been a major focus of energy policy, this online campaign delivering practical advice on ways of reducing energy consumption appears to have had a considerable effect on ordinary citizens.

- Publicizing of the power-saving targets set by the EPCOs as well as the background necessitating curbs on peak demand.

- Suggesting 'menus' of action to help users to achieve these targets.

- Devising specific menus of action into several types for different categories of user (ranging from ordinary households to various categories of industry) and explaining points to note regarding their implementation. ${ }^{49}$

- Distributing stickers for display by businesses participating in the campaign.

- Advice on development of power-saving action plans.

- Suggesting ways of confirming attainment of power-saving action plans on invoices and meter reading slips.

- Issuing power-saving attainment certificates.

- Presenting awards by campaign sponsors to users who achieve their power-saving targets.

- Showcasing of initiatives undertaken by businesses, local governments, etc., and power-saving partnership events.

- Conducting a questionnaire survey following the campaign and publication of results.

This campaign was run also in the winter of 2011-12.

Widespread voluntary action was also undertaken in the private sector to save electricity. Keidanren (the Japanese Business Federation), for example, urged its members to develop voluntary action plans to cut electricity consumption, and some 820 companies took part in this program in eastern Japan. Keidanren followed this up with a questionnaire survey of the types of action taken by its members, the results of which are shown in Table 15.

49 For example, different menus of action were suggested for ordinary homes, office buildings, wholesalers and retailers, food supermarkets, medical facilities, hotels, restaurants, schools, and manufacturers. 
Table 15: Results of questionnaire survey of Keidanren members

\begin{tabular}{|l|c|c|c|}
\hline \multirow{2}{*}{ Type of action } & \multicolumn{3}{c|}{ Implementation rate (\%) } \\
\cline { 2 - 4 } & All & Manufacturers & Non-manufacturers \\
\hline Better use of lighting and air conditioning & 83 & 72 & 100 \\
\hline Better use of other equipment & 44 & 25 & 74 \\
\hline $\begin{array}{l}\text { Installation and use of own generating equipment and storage } \\
\text { batteries }\end{array}$ & 41 & 60 & 12 \\
\hline Shift of operations to holidays, etc. & 40 & 51 & 24 \\
\hline Shift of operations to nights/early morning, etc. & 28 & 43 & 3 \\
\hline $\begin{array}{l}\text { Installation of energy-saving lighting and air-conditioning } \\
\text { facilities }\end{array}$ & 16 & 6 & 32 \\
\hline $\begin{array}{l}\text { Rescheduling of production and equipment inspection/repair } \\
\text { times }\end{array}$ & 10 & 15 & 3 \\
\hline Installation of energy-saving systems other than the above & 5 & 4 & 6 \\
\hline $\begin{array}{l}\text { Reduction of production activity to reduce power } \\
\text { consumption }\end{array}$ & 5 & 6 & 3 \\
\hline Movement of business activities to other parts of Japan & 3 & 6 & 0 \\
\hline Not otherwise specified & 20 & 13 & 24 \\
\hline
\end{tabular}

Source: Keidanren

According to the 'Follow-up Results of Electricity-Demand Measures in Summer (Verification of Approaches by Large and Small Electricity Customers and Households)' published by the Agency for Natural Resources and Energy in December 2011, the energy savings summarized in Table 16 were achieved as a result of this collaborative action by the public and private sectors.

Table 16: Peak load and power consumption compared with previous year

\begin{tabular}{|l|c|c|c|c|}
\hline & TEPCO & Tohoku E & Kansai E & Kyusyu E \\
\hline Target for 'demand cut' & $-15 \%$ & $-15 \%$ & $-10 \%$ & - \\
\hline Outcome (Peak Load kW yoy) & $-29 \%$ & $-18 \%$ & $-9 \%$ & $-6 \%$ \\
\hline Large customers & $-19 \%$ & $-20 \%$ & $-10 \%$ & $-13 \%$ \\
\hline Small customers & $-6 \%$ & $-22 \%$ & $-14 \%$ & $-14 \%$ \\
\hline Residential & $-12 \%$ & $-16 \%$ & $-2.1 \%$ & $-0.3 \%$ \\
\hline Outcome (Consumption KWh yoy) & $-17 \%$ & & & \\
\hline Large customers & $-17 \%$ & $-17 \%$ & $-9.5 \%$ & $-5.1 \%$ \\
\hline Residential
\end{tabular}

Note: Large users are customers with contracted demand of $500 \mathrm{~kW}$ and above, and small users of less than $500 \mathrm{~kW}$.

Source: METI, 'Follow-up Results of Electricity Supply-Demand Measures for this

Summer', 14 Oct. 2011. 


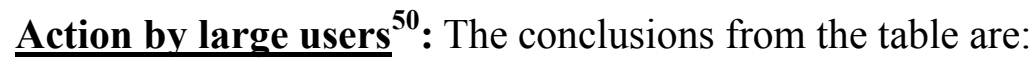

- The large users succeeded in taking effective steps to curb demand, ${ }^{51}$ but faced higher costs due to making use of self-generated power and adjusting production in order to avoid having to cut output.

- Businesses with large production operations found it hard to achieve their targets solely by means of reducing lighting (e.g., by switching off unnecessary lighting, installing LED lights) and air-conditioning power consumption (e.g., by setting air conditioning to $28^{\circ} \mathrm{C}$ ) and/or by shifting weekday production to holidays.

- The extent to which power savings could be achieved while minimizing the impact on production devolved largely upon office-based operations (e.g., air conditioning and lighting), and power savings were within the range $0 \%-15 \%$. (In the summer, in other words, many businesses saw production suffer in some form or other.)

\section{$\underline{\text { Action by small users }}^{52}$ :}

- Responding to government requests to save power, small and medium-sized businesses set about cutting their electricity consumption by at least $15 \%-20 \%$. As a result, approximately $26 \%$ managed to cut peak demand by at least $20 \%$, and approximately $41 \%$ achieved cuts of at least $15 \%$.

- The main forms of action taken included shifting regular weekday operations to other days, making sure that all equipment not in use was properly switched off, limiting use of air conditioners and lighting, switching to use of energy-saving appliances and self-generating electricity, changing working hours, raising energy awareness among employees, and using demand-monitoring systems.

\section{$\underline{\text { Action by ordinary households }}^{\mathbf{5 3}}$ :}

- While $5.8 \%$ of households reported that they 'had to make noticeable sacrifices to save power', the majority said that they managed to cut their power use without making excessive adjustments to their lives.

- At least $90 \%$ of households reported that they would continue to save electricity. Over $60 \%$ said that they could cut their power consumption by at least $10 \%$.

- Households achieved electricity savings in the following ways: switching off lights as much as possible $(81 \%)$, using fans instead of air conditioners $(77 \%)$, setting air conditioners to $28^{\circ} \mathrm{C}(73 \%)$, unplugging electrical appliances from the wall $(70 \%)$, changing refrigerator settings from 'strong' to 'medium' and opening the

50 Large users with demand of from several thousand to over a million kilowatts in industries such as iron and steel, chemicals, non-ferrous metals, electronics, automobiles, precision instruments and consumer electronics, and office buildings.

51 According to questionnaire findings, firms generally managed to reduce their peak load by $20 \%-40 \%$. Cases of firms managing cuts of almost $70 \%$ are also reported.

52 Mainly small and medium-sized businesses, convenience stores, and similar users in the commercial sector.

53 Random sample of 1,200 selected from residential customers in the TEPCO's and Tohoku EPCO's service areas. 
refrigerator as little as possible (65\%), and lowering TV brightness $(63 \%)$.

A nationwide power-saving campaign was again run this winter (without legal obligation) with the aim of keeping within electricity reserve margins, and its effects are being watched with interest.

Table 17: FY 2011 winter campaign to save electricity

\begin{tabular}{|c|c|c|c|}
\hline Region & Target & Period (excluding 29 Dec. -4 Jan.) & Hours \\
\hline \multirow{4}{*}{ Kansai EPCO } & No numerical target & 1-16 Dec. and 26-30 Mar. & \multirow{2}{*}{$\begin{array}{c}\text { Weekdays } \\
09: 00-21: 00\end{array}$} \\
\cline { 2 - 3 } & $\begin{array}{c}10 \% \text { cut in peak } \\
\text { demand }\end{array}$ & 19 Dec. -23 Mar. & Weekdays \\
Kyushu EPCO & No numerical target & 1-22 Dec. and 6 Feb. -30 Mar. & 08:00-21:00 \\
\cline { 2 - 3 } & $\begin{array}{c}5 \% \text { cut in peak } \\
\text { demand }\end{array}$ & 25 Dec. -3 Feb. & $\begin{array}{c}\text { Weekdays } \\
09: 00\end{array}$ \\
\hline $\begin{array}{c}\text { Others excluding } \\
\text { Okinawa }\end{array}$ & No numerical target & 1 Dec. -30 Mar. & \multicolumn{2}{c}{} \\
\hline
\end{tabular}

Source: METI 


\section{Estimating LNG Demand ${ }^{54}$ in the Electricity Generation Sector}

\subsection{Framework and Approach}

\subsubsection{Framework of estimation}

The overall framework for estimating future LNG demand in the electricity generation sector is summarized as follows;

- The LNG demand for electricity generation ${ }^{55}$ of each of Japan's general electric utilities (10 utilities) was estimated in each fiscal year up to FY 2020.

- The underlying numbers used to calculate these estimates (e.g., installed nuclear, thermal, and hydro generating capacity and utilities' peak loads) are based on the Electric Power Supply Program for Fiscal 2010. ${ }^{56}$

- Estimates were calculated by the following process:

Seasonal load curves were estimated for each electric utility.

> A simplified dispatch model corresponding to each utility's generating capacity by power source was applied to these load curves to calculate the output of each LNG power plant.

From this output, we then calculated the amount of LNG required as fuel.

\subsubsection{Electricity demand assumptions by estimating seasonal load curves}

Demand-side changes (particularly, due to energy saving activities) have to be reflected as accurately as possible in order to estimate LNG demand with rigour. We therefore made the following assumptions about demand.

- Each electric utility's year was divided into three seasons - summer, winter, and autumn/spring - and conventional load curves were estimated for weekdays and non-weekdays during each of these seasons, creating six categories (in each utility) .

- Factors including the projected operating status of nuclear power facilities, reserve margins, the post-quake economic downturn, and improvements in energy conservation $^{57}$ were taken into account in estimating the peak load reduction rates

54 LNG demand estimated by the model here is defined as demand for LNG consumed for electricity generation by the 10 electrical utilities. In practice, other companies (such as major city gas companies) engage in thermal power generation using LNG and there are also many self-generators that use city gas as fuel. To allow more effective sensitivity analysis of the model, however, we consider only general electrical utilities' demand in this section.

55 LNG used by electric utilities for other purposes (e.g., production of city gas) is not included here, but instead included in city gas and other demand considered in the following section.

56 Central Electric Power Council, March 2010.

57 In the medium to long term, 'smart meters' are expected to play a particularly effective role in reducing peak load, and the TEPCO Management and Finance Investigation Committee is calling for 
for each utility. ${ }^{58}$

- Peak load in each season of each year was estimated allowing for these peak load reductions. Peak loads over the course of the year are given in the Electric Power Supply Program for Fiscal 2010, and peak loads for other seasons were set according to the actual demand experienced by each utility based on this peak load.

- The changes in load curve shape arising from peak load reductions were estimated incorporating changes since 11 March (see Figure 14) ${ }^{59}$.

Table 18: Premised peak load reduction rates of nine EPCOs (\%)

Base Scenario \& Renuclearization Scenario

\begin{tabular}{|l|c|c|c|c|c|c|c|c|c|c|c|c|}
\hline & 2009 & 2010 & 2011 & 2012 & 2013 & 2014 & 2015 & 2016 & 2017 & 2018 & 2019 & 2020 \\
\hline Hokkaido & 0 & 0 & 0 & 10 & 5 & 5 & 5 & 5 & 5 & 5 & 5 & 5 \\
\hline Tohoku & 0 & 0 & 15 & 5 & 5 & 5 & 5 & 5 & 5 & 5 & 5 & 5 \\
\hline Tokyo & 0 & 0 & 15 & 15 & 5 & 5 & 5 & 5 & 5 & 5 & 5 & 5 \\
\hline Chubu & 0 & 0 & 5 & 5 & 5 & 5 & 5 & 5 & 5 & 5 & 5 & 5 \\
\hline Hokuriku & 0 & 0 & 5 & 10 & 5 & 5 & 5 & 5 & 5 & 5 & 5 & 5 \\
\hline Kansai & 0 & 0 & 10 & 20 & 5 & 5 & 5 & 5 & 5 & 5 & 5 & 5 \\
\hline Cuhgoku & 0 & 0 & 0 & 5 & 5 & 5 & 5 & 5 & 5 & 5 & 5 & 5 \\
\hline Shikoku & 0 & 0 & 5 & 15 & 5 & 5 & 5 & 5 & 5 & 5 & 5 & 5 \\
\hline Kyushu & 0 & 0 & 5 & 15 & 5 & 5 & 5 & 5 & 5 & 5 & 5 & 5 \\
\hline
\end{tabular}

Denuclearization Scenario

\begin{tabular}{|l|c|c|c|c|c|c|c|c|c|c|c|c|}
\hline & 2009 & 2010 & 2011 & 2012 & 2013 & 2014 & 2015 & 2016 & 2017 & 2018 & 2019 & 2020 \\
\hline Hokkaido & 0 & 0 & 0 & 10 & 10 & 10 & 10 & 10 & 10 & 10 & 10 & 10 \\
\hline Tohoku & 0 & 0 & 15 & 5 & 5 & 5 & 5 & 5 & 5 & 5 & 5 & 5 \\
\hline Tokyo & 0 & 0 & 15 & 15 & 15 & 15 & 15 & 15 & 15 & 15 & 15 & 15 \\
\hline Chubu & 0 & 0 & 5 & 5 & 5 & 5 & 5 & 5 & 5 & 5 & 5 & 5 \\
\hline Hokuriku & 0 & 0 & 5 & 10 & 10 & 10 & 10 & 10 & 10 & 10 & 10 & 10 \\
\hline Kansai & 0 & 0 & 10 & 20 & 20 & 20 & 20 & 20 & 20 & 20 & 20 & 20 \\
\hline Chugoku & 0 & 0 & 0 & 5 & 5 & 5 & 5 & 5 & 5 & 5 & 5 & 5 \\
\hline Shikoku & 0 & 0 & 5 & 15 & 15 & 15 & 15 & 15 & 15 & 15 & 15 & 15 \\
\hline Kyusyu & 0 & 0 & 5 & 15 & 15 & 15 & 15 & 15 & 15 & 15 & 15 & 15 \\
\hline
\end{tabular}

investment in the installation of such devices, which are projected to enable peak loads to be cut by around 5\%.

58 For details of the relationship between the peak load reduction rate and electricity demand in this model, see Appendix 6.

59 For example, TEPCO's load curves were published on its web-site after 11 March 
Table 19: Actual and premised peak loads of EPCOs

Base Scenario

(GW)

\begin{tabular}{|l|r|r|r|r|r|r|r|r|r|r|r|r|}
\hline & \multicolumn{1}{|c|}{2009} & \multicolumn{1}{|c|}{2010} & 2011 & 2012 & 2013 & 2014 & 2015 & 2016 & 2017 & 2018 & 2019 & 2020 \\
\hline Hokkaido & 5.3 & 5.29 & 5.47 & 4.97 & 5.29 & 5.35 & 5.42 & 5.47 & 5.53 & 5.60 & 5.66 & 5.72 \\
\hline Tohoku & 12.70 & 13.75 & 11.77 & 13.25 & 13.36 & 13.46 & 13.57 & 13.72 & 13.87 & 14.02 & 14.17 & 14.24 \\
\hline Tokyo & 59.14 & 59.37 & 50.66 & 50.86 & 57.07 & 57.29 & 57.52 & 57.74 & 57.97 & 58.20 & 58.43 & 58.65 \\
\hline Chubu & 23.17 & 26.21 & 24.32 & 24.57 & 24.75 & 24.93 & 25.11 & 25.28 & 25.46 & 25.64 & 25.82 & 26.00 \\
\hline Hokuriku & 4.73 & 5.43 & 5.00 & 4.77 & 5.08 & 5.12 & 5.16 & 5.20 & 5.25 & 5.29 & 5.34 & 5.39 \\
\hline Kansai & 27.23 & 30.09 & 26.60 & 23.79 & 28.40 & 28.54 & 28.68 & 28.76 & 28.83 & 28.91 & 28.98 & 29.06 \\
\hline Chugoku & 10.26 & 11.57 & 11.35 & 11.54 & 11.64 & 11.74 & 11.84 & 11.93 & 12.02 & 12.11 & 12.20 & 12.29 \\
\hline Shikoku & 5.15 & 5.72 & 5.21 & 4.68 & 5.25 & 5.28 & 5.30 & 5.32 & 5.34 & 5.37 & 5.39 & 5.41 \\
\hline Kyushu & 16.01 & 16.76 & 15.86 & 14.31 & 16.14 & 16.28 & 16.42 & 16.55 & 16.69 & 16.83 & 16.97 & 17.11 \\
\hline
\end{tabular}

Note: Peak load reduction rates in Table 18 are applied to peak loads published in the "Electric Power Supply Program for Fiscal 2010" by The Central Electric Power Council.

Figure 14: Changes in shapes of load curves

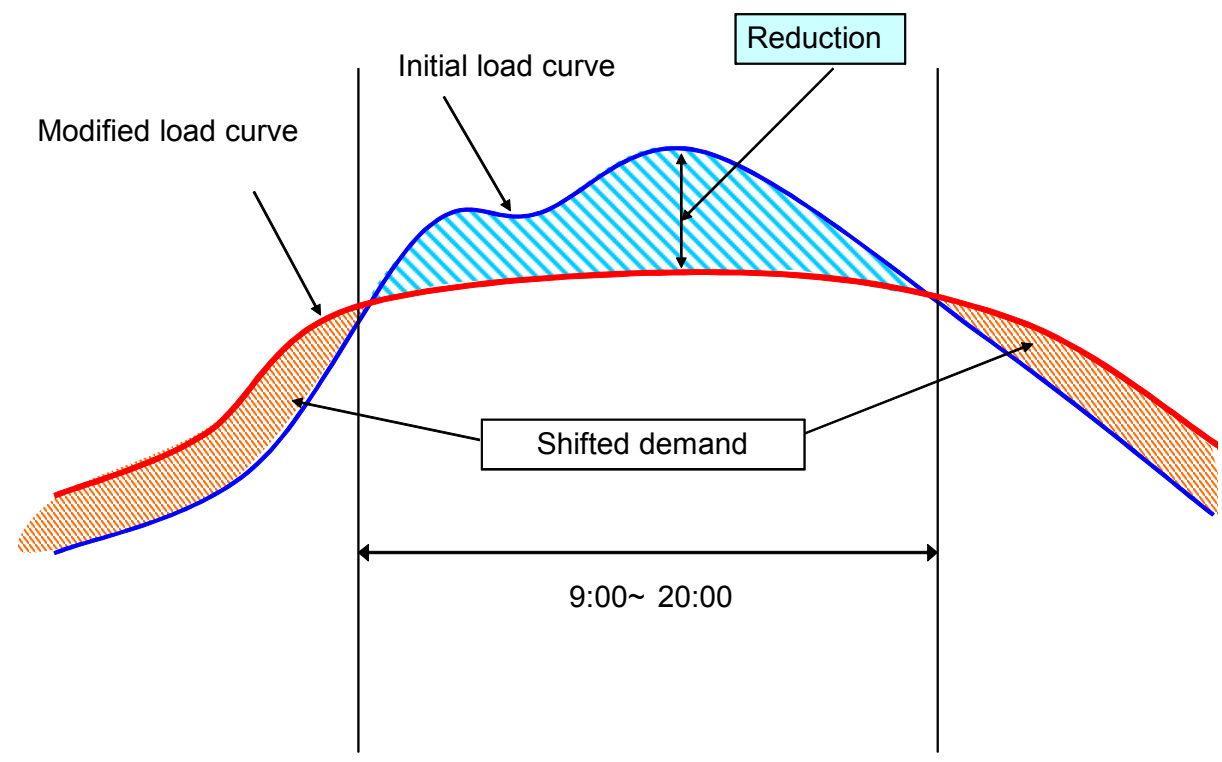

Source: Authors' Analysis 


\subsubsection{Main assumptions for power supply}

Japan has traditionally used nuclear power, hydropower, and coal as its main base load power sources, with LNG power generation being used as a middle to peak load power source and oil and pumped storage power generation being used for peak load. Assuming this basic structure, we estimated dispatch based on the load curves described in the preceding section. LNG thermal power is dispatched from each plant in order of thermal efficiency, and power generated volume is calculated based on each plant's load factor.

\section{Figure 14: Dispatch assumptions}

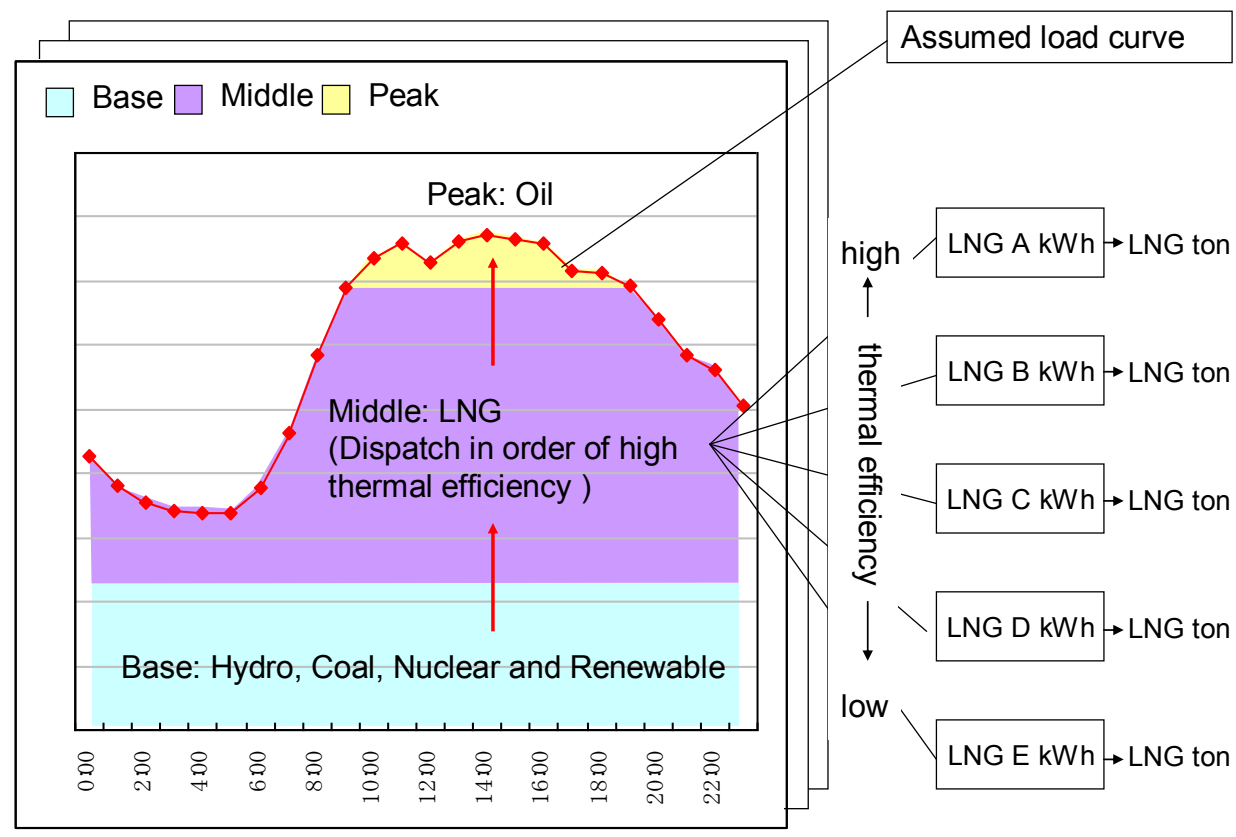


Table 20: Estimated installed capacity of 10 EPCOs' natural gas power plants (GW)

\begin{tabular}{|l|r|r|r|r|r|r|r|r|r|r|r|r|}
\hline & 2009 & 2010 & 2011 & 2012 & 2013 & 2014 & 2015 & 2016 & 2017 & 2018 & 2019 & 2020 \\
\hline Hokkaido & 0 & 0 & 0 & 0 & 0 & 0 & 0 & 0 & 0 & 0 & 0 & 0.5 \\
\hline Tohoku & 5.0 & 5.4 & 4.9 & 5.3 & 4.9 & 4.9 & 4.9 & 5.4 & 5.9 & 5.9 & 5.9 & 5.9 \\
\hline Tokyo & 24.0 & 24.5 & 25.4 & 26.0 & 26.0 & 26.0 & 26.0 & 26.7 & 27.4 & 27.4 & 27.4 & 27.4 \\
\hline Chubu & 14.5 & 14.5 & 14.5 & 15.1 & 16.3 & 16.9 & 16.9 & 16.9 & 16.9 & 16.9 & 19.2 & 19.2 \\
\hline Hokuriku & 0 & 0 & 0 & 0 & 0 & 0 & 0 & 0 & 0 & 0.4 & 0.4 & 0.4 \\
\hline Kansai & 7.0 & 6.9 & 6.9 & 6.9 & 5.7 & 7.2 & 8.2 & 8.2 & 8.2 & 8.2 & 8.2 & 8.2 \\
\hline Chugoku & 2.0 & 2.0 & 2.0 & 2.0 & 2.0 & 2.0 & 2.0 & 2.0 & 2.0 & 2.0 & 2.0 & 2.0 \\
\hline Shikoku & 0 & 0.7 & 0.7 & 0.7 & 0.7 & 0.7 & 0.7 & 0.9 & 0.9 & 0.9 & 0.9 & 0.9 \\
\hline Kyusyu & 4.1 & 4.1 & 4.1 & 4.1 & 4.1 & 4.5 & 4.5 & 4.5 & 4.5 & 4.5 & 4.5 & 4.5 \\
\hline Okinawa & 0 & 0 & 0 & 0.1 & 0.4 & 0.5 & 0.5 & 0.6 & 0.8 & 0.8 & 0.8 & 0.8 \\
\hline Total & 56.6 & 58.1 & 58.5 & 60.2 & 60.1 & 62.7 & 63.7 & 65.2 & 66.6 & 67.0 & 69.3 & 69.8 \\
\hline
\end{tabular}

\subsubsection{Scenario development and assumptions}

As of April 2012, few concrete details had been determined concerning such matters as the timetable of recommencement of operations at nuclear plants following stress testing, the timing of decommissioning of aging reactors, and policy on development of new nuclear plants currently under construction or at the planning stage. The situation now is extremely unclear due to the need to ensure consistency with the long-term energy policy to be announced in mid-2012 and the fact that, even once this policy has been finalized, accommodations will still have to be reached with all these nuclear power stations' host communities and administrations. ${ }^{60}$

Bearing these points in mind, the following general conclusions may be drawn from the wide-ranging debate so far on the future of nuclear power in Japan:

- Several nuclear power stations that have already reported the results of their stress tests may come back online in time for the 2012 summer peak demand period but the situation would be highly dependent on political discussions.

- While it is likely that aging reactors will be decommissioned after 40 years of service, it is also possible that exceptions may be made to allow some to operate for up to 60 years. ${ }^{61}$

- The environment is extremely hostile to new construction. However, projects on

\footnotetext{
60 The question of how long the present Democratic Party administration will remain in power adds a further element of uncertainty.

${ }^{61}$ As indicated by the nuclear disaster minister.
} 
which starts have already been made and that are already quite advanced may be continued to the point that they enter operation.

Given these conditions, we adopt the most likely case as our base scenario. The other two scenarios assume outcomes that presently appear unlikely, but are here included for the purpose of comparison to gauge the extent of their possible impact on LNG demand.

Table 21: Main assumptions common to all scenarios

\begin{tabular}{|l|l|}
\hline \multicolumn{1}{|c|}{ Conditions } & \multicolumn{1}{c|}{ Common assumptions } \\
\hline Restart of existing plants & Fukushima I and II not restarted \\
\cline { 2 - 2 } & Hamaoka not restarted \\
\hline $\begin{array}{l}\text { Maximum availability factor of LNG power plants } \\
\text { (annual) }\end{array}$ & $70 \%{ }^{62}$ \\
\hline Generating efficiency of LNG power plants & Determined for each plant \\
\hline
\end{tabular}

Table 22: Assumptions for individual scenarios ${ }^{64}$

\begin{tabular}{|l|l|l|l|}
\hline & \multicolumn{1}{|c|}{$\begin{array}{c}\text { Restart of existing nuclear power } \\
\text { plants }\end{array}$} & \multicolumn{1}{|c|}{ Aging reactors } & \multicolumn{1}{c|}{ New plants } \\
\hline Base scenario & $\begin{array}{l}\text { All shut down in FY2012 } \\
\text { Restarted from 2013 }\end{array}$ & $\begin{array}{l}\text { Decommissioning after } \\
40 \text { years of service }\end{array}$ & $\begin{array}{l}\text { Only Shimane Unit 3 } \\
\text { and Oma commence } \\
\text { operation }\end{array}$ \\
\hline $\begin{array}{l}\text { Renuclearization } \\
\text { scenario }\end{array}$ & $\begin{array}{l}\text { All shut down in FY 2012 } \\
\text { Restarted from 2013 }\end{array}$ & $\begin{array}{l}\text { Not decommissioned } \\
\text { after 40 years of service }\end{array}$ & $\begin{array}{l}\text { Only Shimane Unit 3 } \\
\text { and Oma enter service }\end{array}$ \\
\hline $\begin{array}{l}\text { Denuclearization } \\
\text { scenario }\end{array}$ & All shut down by April 2012 and none brought back online & None enter service \\
\hline
\end{tabular}

62 This figure is based on actual data for FY 2007 and interviews with experts.

63 Determined based on actual figures for FY 2007 (METI, Denryokujyukyu no Gaiyo, Outline of Supply and Demand of Electricity). The efficiency of new plants was based on information contained in utilities' press releases (assumed to be $59 \%$ for the most efficient plants and $36 \%$ for the least efficient).

64 Detailed premises for each plant are given in appendix 4. 


\subsection{Estimation Results}

\subsubsection{LNG demand outlook for the power generation sector}

The results of estimates for each scenario are shown in Table 23.

Table 23: Summary of estimation results

\begin{tabular}{|c|c|c|}
\hline $\begin{array}{c}\text { Fiscal } \\
\text { year }\end{array}$ & Scenario & Summarized results (approximate figures) \\
\hline 2011 & All three & $\begin{array}{l}\text { - Fiscal year's load factor is projected to be } 24 \% \text { due to the progressive } \\
\text { shutdown of existing power stations following scheduled inspection. } \\
\text { LNG demand is estimated to grow by } 10.5 \mathrm{mt} \text { from a year earlier to } 52.2 \mathrm{mt} \\
\text { in FY2011. Actual imports were } 42.9 \mathrm{mt} \text { (from April) up to January } 2012 \text {. } \\
\text { Estimating fiscal year demand on this basis yields a figure of } 52.4 \mathrm{mt} \text {, } \\
\text { indicating the estimation model to largely mirror the actual situation. }\end{array}$ \\
\hline 2012 & All three & $\begin{array}{l}\text { - As it is assumed that all nuclear power stations will be offline, LNG } \\
\text { demand will grow by } 1.6 \mathrm{mt} \text { from a year earlier to } 53.9 \mathrm{mt} \text {. } \\
\text { - This is a } 12.1 \mathrm{mt} \text { increase compared with FY } 2010 \text {. }\end{array}$ \\
\hline \multirow{3}{*}{$\begin{array}{l}\text { Trends } \\
\text { from } \\
2013\end{array}$} & Base & $\begin{array}{l}\text { - As it is assumed that existing power stations will come back online from FY } \\
\text { 2013, LNG demand will decline } 9.0 \mathrm{mt} \text { from a year earlier. } \\
\text { - Progressive decommissioning after } 40 \text { years of service and albeit slight } \\
\text { growth in electricity demand will cause LNG demand to trend upward until } \\
2020 \text {. }\end{array}$ \\
\hline & Renuclearization & $\begin{array}{l}\text { - With the restart of existing power stations from FY 2013, demand will } \\
\text { decline } 9.4 \mathrm{mt} \text { from a year earlier. } \\
\text { - LNG demand will thereafter trend slightly upward with growth in electricity } \\
\text { demand. }\end{array}$ \\
\hline & Denuclearization & $\begin{array}{l}\text { - With nuclear power remaining completely offline, LNG demand will } \\
\text { continue to increase in parallel with growth in electricity demand from FY } \\
2013 \text { to } 2020 \text {. }\end{array}$ \\
\hline \multirow{3}{*}{2020} & Base & $\begin{array}{l}\text { - } 49.4 \mathrm{mt} \text {, down } 4.4 \mathrm{mt} \text { from FY } 2012 \text { when nuclear power was completely } \\
\text { offline. This is up } 7.7 \mathrm{mt} \text { from FY } 2010 \text { before } 11 \mathrm{March} \text {. }\end{array}$ \\
\hline & Renuclearization & $\begin{array}{l}46.2 \mathrm{mt} \text {, down } 6.0 \mathrm{mt} \text { from FY } 2012 \text { when nuclear power was completely } \\
\text { offline. This represents a } 4.5 \mathrm{mt} \text { increase from FY } 2010 \text { before } 11 \text { March. }\end{array}$ \\
\hline & Denuclearization & $\begin{array}{l}\text { - Up } 2.9 \mathrm{mt} \text { from FY } 2012 \text { when nuclear power was completely offline to } \\
56.7 \mathrm{mt} \text {. This represents a } 15 \mathrm{mt} \text { increase from FY } 2010 \text { before } 11 \text { March. }\end{array}$ \\
\hline
\end{tabular}




\section{Projected LNG demand in the electricity generation sector:}

Figure 16: LNG demand estimates for the electricity generation sector - mtpa

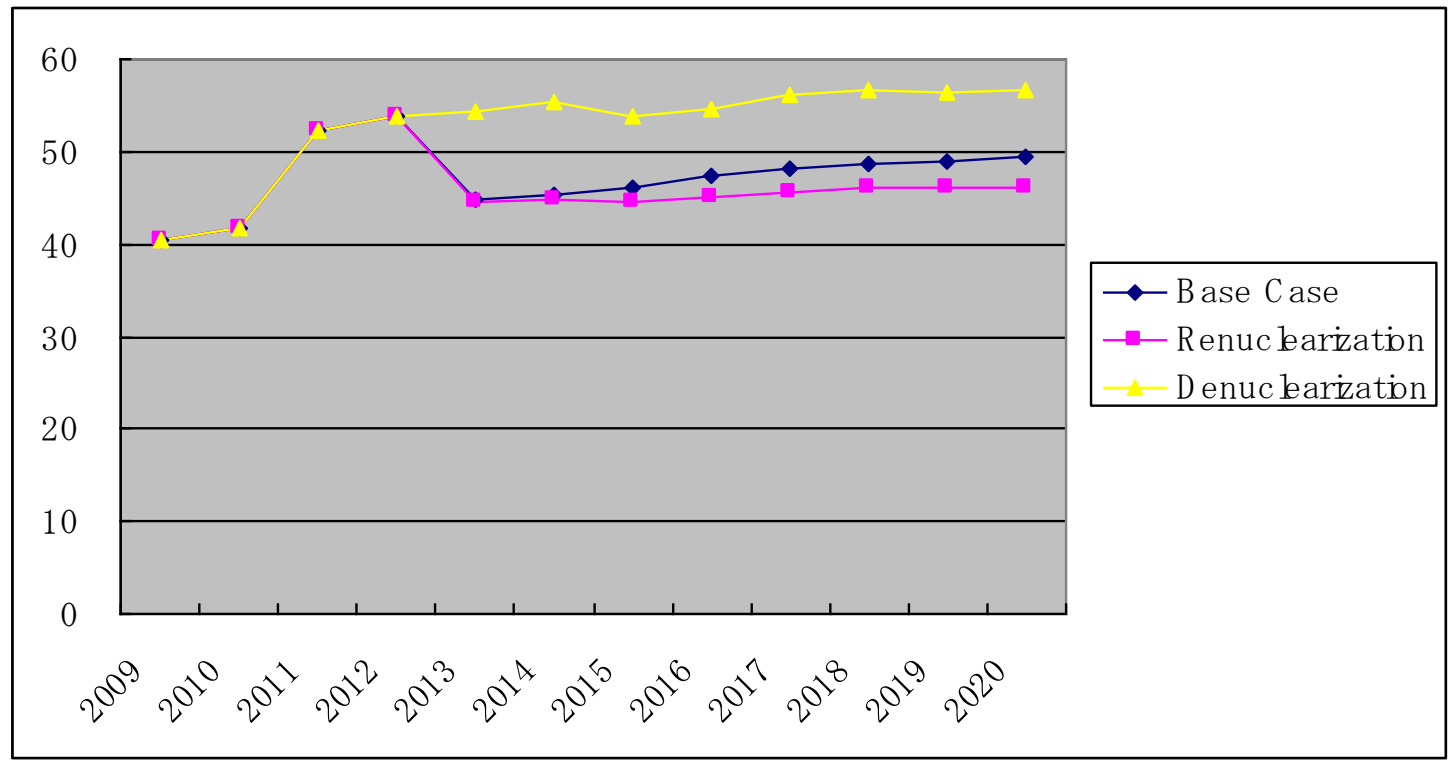

Note: 2009, 2010; Actual Consumption

Source: Authors' modeled analysis

\subsubsection{Observations for individual electric power companies}

When we focus on the next decade, the key considerations may be narrowed down to the following two questions: When will existing nuclear power stations be restarted? And will aging reactors be decommissioned at 40 years or will they remain in operation beyond this life span? Regarding the first question, it is likely that, as noted above, plants that have passed their stress tests will begin to come back online from around the summer of 2012. On the second question, the most likely outcome is that reactors will, as a rule, be decommissioned at 40 years, but that certain exceptions may be made.

Accordingly, the most likely possibility is that LNG demand will be lower than anticipated in FY 2012, and will fall somewhere between the base scenario and the renuclearization scenario (i.e., the base scenario will represent the upper ceiling) from FY 2013 onward.

The main points to note concerning individual utilities can be briefly summarized as follows:

- In TEPCO's case, the low probability of Fukushima I and II being restarted means that future LNG demand is estimated to be in the region of 21-23 million tons per year irrespective of other conditions. 
- In Chubu EPCO's case, demand will be a constant 12-13 million tons per year, regardless of conditions, if Hamamatsu cannot be brought back online.

- In Kansai EPCO's case, seven reactors will reach the 40-year mark by FY 2020, and so its demand for LNG could vary considerably depending on what policy is adopted on aging reactors. In the base scenario, demand in FY 2020 may increase by the level in FY 2012 (around 6.70 million tons) when nuclear power was completely offline.

(In every case, it must be borne in mind that there will be no new construction of LNG thermal capacity beyond that indicated in the assumptions.) 


\section{LNG Demand Outlook for the City Gas Sector}

\subsection{Framework for Estimation of LNG Demand in the City Gas Sector}

The overall framework employed for the estimation process was as follows.

- Dividing the demand for LNG for city gas use into three categories (residential, commercial, and industrial), a study was made of the factors defining demand in each sector and then a regression analysis performed to estimate demand up to FY 2020.

- Structurally, Japan's city gas market is distinguished by the large proportion of total sales accounted for by the three leading utilities and the regional characters of these three utilities' markets (i.e., the gas markets of the Tokyo metropolitan region, the Chubu region of central Honshu, and the Kinki region of western-central Honshu). In addition to estimating demand in Japan as a whole, therefore, we estimated demand from these three utilities by the same method for the purpose of comparison.

- All LNG demand not included in the LNG demand of the power generation sector is included in the demand estimates described in this section.

The main variables considered in the estimates were as shown in Figure 17.

Figure 17: Principal city gas market variables

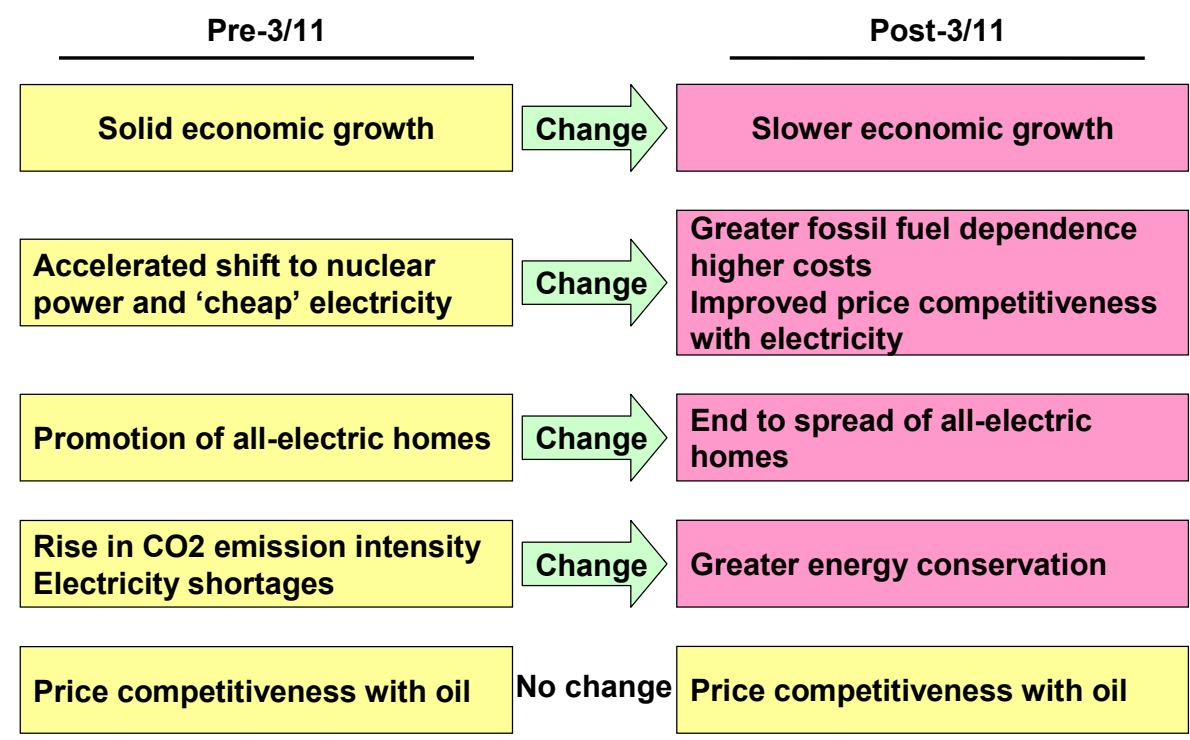




\subsection{Approach and Main Assumptions for Estimating Demand}

\subsubsection{Framework for estimation of residential demand}

Residential LNG demand was basically estimated as follows;

Residential LNG consumption =

Unit gas consumption per household $\times$ Number of gas-consuming households

Figure 18: Approach for estimating residential demand

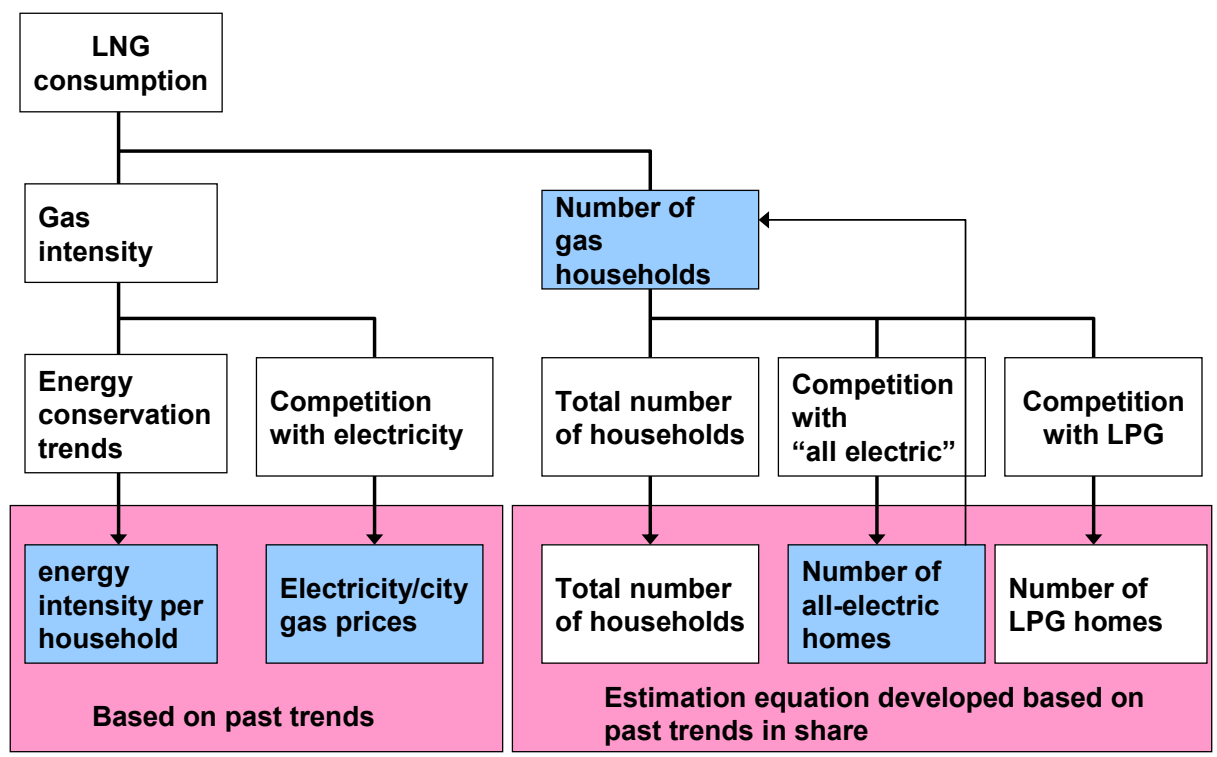

Regarding unit gas consumption per household, a regression analysis was performed by using total unit energy consumption per household and the city gas/electricity price ratio. Trends and assumptions regarding these two items are shown in the table below. 
Table 24: Trends in unit gas consumption and assumptions (Residential sector)

\begin{tabular}{|c|c|c|}
\hline Factor & Pre-11 March trends & Assumptions for projections \\
\hline $\begin{array}{l}\text { Unit energy } \\
\text { consumption per } \\
\text { household }\end{array}$ & $\begin{array}{l}\text { - A target of cutting GHG emissions by } 25 \% \\
\text { from } 1990 \text { levels by } 2020 \text { was adopted by the } \\
\text { Hatoyama administration in the face of strong } \\
\text { opposition from industry and other quarters, } \\
\text { and many doubt this target's feasibility. } \\
\text { - Plans to promote less } \mathrm{CO}_{2} \text { emission energy by } \\
\text { shifting to nuclear power were adopted. }\end{array}$ & $\begin{array}{l}\text { - For the base scenario, the GHG reduction target for } \\
2020 \text { was assumed to be a realistic }-5 \% \text {. } \\
\text { - Assuming that } \mathrm{CO}_{2} \text { reductions will be achieved by } \\
\text { energy conservation if nuclear power is cut, unit } \\
\text { total energy consumption would be reduced } \\
\text { approximately } 6 \% \text { by } 2020^{65} \text { in the base scenario. }\end{array}$ \\
\hline $\begin{array}{l}\text { City } \\
\text { gas/electricity } \\
\text { price ratio }\end{array}$ & $\begin{array}{l}\text { - Pre-3/11, the shift to nuclear power was } \\
\text { expected to keep electricity rates low. } \\
\text { - Rising fossil fuel prices tended to make } \\
\text { electricity more price competitive against gas. }\end{array}$ & $\begin{array}{l}\text { - If nuclear power is replaced by thermal power, } \\
\text { electricity rates will have to rise due to higher fuel } \\
\text { costs and a 5\% increase in FY } 2015 \text { is assumed for } \\
\text { the base scenario. }{ }^{66}\end{array}$ \\
\hline
\end{tabular}

Table 25: Trends in number of households using gas and assumptions

\section{(Residential sector)}

\begin{tabular}{|c|c|c|}
\hline Factor & Pre-11 March trends & Assumptions for projections \\
\hline $\begin{array}{l}\text { Number of } \\
\text { households using } \\
\text { gas }\end{array}$ & $\begin{array}{l}\text { - The total number of households in Japan is still } \\
\text { increasing slightly, although the population } \\
\text { has already entered a downward trend. } \\
\text { - The rate of growth in the number of gas } \\
\text { households slowed with the growth in } \\
\text { all-electric homes. } \\
\text { - All-electric homes grew rapidly nationwide } \\
\text { from the beginning of the } 2000 \mathrm{~s} \text {, and had } \\
\text { reached a total of } 4.4 \text { million as of } 2010 .^{68}\end{array}$ & $\begin{array}{l}\text { - Average annual rate of growth in total number of } \\
\text { households: }{ }^{6} \\
+0.1 \% \text { /year from } 2010 \text { to } 2015 \\
-0.1 \% / \text { year from } 2015 \text { to } 2020 \\
\text { - Since } 3 / 11 \text {, electric utilities have refrained from } \\
\text { promoting all-electric homes due to electricity } \\
\text { shortages, and the rate of growth is projected to } \\
\text { fall. }^{70} \text { For our calculations, therefore, it was } \\
\text { assumed that the rate of growth in gas households } \\
\text { would return to what it was before all-electric } \\
\text { homes began to be promoted. }\end{array}$ \\
\hline
\end{tabular}

${ }^{65}$ The increase in $\mathrm{CO}_{2}$ emissions is calculated assuming that the decrease in nuclear power output is replaced by thermal power generation using natural gas. A $6.2 \%$ reduction in unit energy consumption will be required if a reduction commensurate with this increase is to be achieved through energy conservation.

66 The Fujitsu Research Institute, for example, estimates that if all nuclear power plants are taken offline from FY 2020 and all plans for fresh construction are halted, electricity rates will have to rise $35 \%$ by 2020 (Nihon Keizai Shimbun, 27 June 2011). Additionally, the TEPCO Management and Finance Investigation Committee has presented financial outlooks for three different rates scenarios: no increase, a $5 \%$ increase, and a $10 \%$ increase. Our margin of increase is here estimated taking into account these sources.

67 An analysis of past trends indicates that growth in the number of gas households accounted for around $70 \%$ of the total increase in households when there were no all-electric homes, but that since the introduction of the all-electric option the rate has slowed to account for only around $50 \%$ of total growth. However, this 'capping effect' varies according to region.

68 The total number of households in Japan was 51.96 million as of Oct.2010.

69 National Institute of Population and Social Security Research, “Household Projections for Japan", March 2008. http://www.ipss.go.jp/pp-ajsetai/j/HPRJ2008/t-page.asp

70 The Denki Shimbun, 24 June 2011. 


\subsubsection{Commercial sector}

LNG demand in the commercial sector was calculated by means of a regression analysis of the four factors shown in Figure 19: total floor area, unit energy consumption in the commercial sector, the oil/LNG price ratio, and the electricity/city gas price ratio.

Figure 19: Approach for estimating city gas demand in the commercial sector

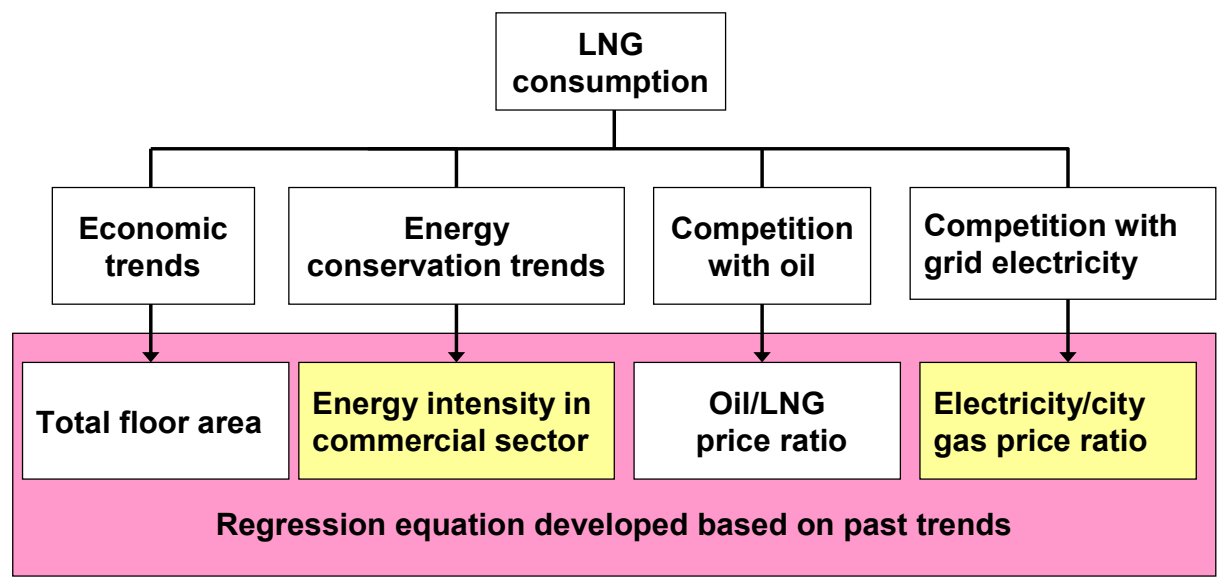


Table 26: Trends and assumptions (Commercial sector)

\begin{tabular}{|c|c|c|c|c|}
\hline Factor & Pre-11 March trends & \multicolumn{3}{|c|}{ Premises for projections } \\
\hline \multirow[t]{4}{*}{ Total floor area } & \multirow{4}{*}{$\begin{array}{l}\text { Total floor area continued to grow strongly } \\
\text { correlated with GDP growth and } \\
\text { demographics (number of households). }\end{array}$} & \multicolumn{3}{|c|}{ Premised GDP growth rates } \\
\hline & & FY 2011 & FY 2012 & FY 2013 onward \\
\hline & & $0.2 \%$ & $2.0 \%$ & $1.4 \%$ \\
\hline & & \multicolumn{3}{|c|}{$\begin{array}{l}\text { Total floor area will continue to increase until FY } \\
\text { 2015, but will then enter a downward trend as the } \\
\text { number of households declines. }\end{array}$} \\
\hline $\begin{array}{l}\text { Unit Energy } \\
\text { consumption } \\
\text { per unit floor } \\
\text { area }\end{array}$ & $\begin{array}{l}\text { Strongly correlated with legislative } \\
\text { developments, plateauing following the } \\
\text { revision of the Energy Conservation Act in } \\
\text { 2003. In addition, since 2007, the rate has } \\
\text { gone into decline due in part to the effects of } \\
\text { the Lehman crisis. }\end{array}$ & \multicolumn{3}{|c|}{$\begin{array}{l}\text { - For the base scenario, the GHG reduction target } \\
\text { for } 2020 \text { was assumed to be a realistic }-5 \% \text {. } \\
\text { - Assuming that } \mathrm{CO}_{2} \text { reductions will be achieved } \\
\text { by energy conservation if nuclear power is cut, } \\
\text { unit total energy consumption will be reduced } \\
\text { approximately } 6 \% \text { by } 2020 .^{71} \\
\text { - It is assumed that unit consumption was reduced } \\
\text { significantly due to power-saving campaigns in } \\
\text { FY 2011-12. It is highly likely that power and } \\
\text { energy savings will continue at the same level as } \\
\text { a result of the installation of equipment (LED } \\
\text { lighting, etc.) and budgeting for energy costs, } \\
\text { etc. From FY 2013, it was assumed that the trend } \\
\text { would remain almost flat. }\end{array}$} \\
\hline $\begin{array}{l}\text { Oil/LNG price } \\
\text { ratio }\end{array}$ & $\begin{array}{l}\text { When oil prices rose, the S-curve effect of } \\
\text { existing long-term LNG contracts resulted in } \\
\text { making LNG more price competitive but this } \\
\text { tendency waned when oil prices fell. }\end{array}$ & \multicolumn{3}{|c|}{$\begin{array}{l}\text { It was assumed that } 11 \text { March would cause no } \\
\text { particular changes, and the traditional correlation } \\
\text { would continue. }\end{array}$} \\
\hline $\begin{array}{l}\text { Electricity/city } \\
\text { gas price ratio }\end{array}$ & $\begin{array}{l}\text { - Pre-11 March, the shift to nuclear power } \\
\text { was expected to keep electricity rates low. } \\
\text { - Rising fossil fuel prices tended to make } \\
\text { electricity prices more competitive against } \\
\text { gas. }\end{array}$ & \multicolumn{3}{|c|}{$\begin{array}{l}\text { - If nuclear power is replaced by thermal power } \\
\text { generation, electricity rates will have to rise due } \\
\text { to higher fuel costs and a } 5 \% \text { increase in FY } \\
2015 \text { is assumed for the base scenario. }{ }^{72}\end{array}$} \\
\hline
\end{tabular}




\subsubsection{Industrial sector}

Industrial LNG demand was basically estimated as follows;

Industrial LNG consumption $=$ total energy consumption in industry $\times$ city gas's share

The main trends in energy consumption and competition between energy sources in the industrial sector pre-11 March are summarized as follows.

As described in the preceding section, city gas consumption by industry exhibited extremely high growth, and its share steadily rose from $2.9 \%$ in FY 1990. Even in FY 2010 , however, it only accounted for around $11.3 \%$ of total industrial energy demand (see Tables 27 and 28 and Figure 20).

Looking at competition among energy sources by use, we find that city gas's main competitors for heating purposes are oil and coal, while as a motive power source it competes mainly with electricity and sometimes cogeneration fuelled by oil products. As a feedstock, it competes with oil and coal, although competition with cheap coal appears limited. City gas's main competitors are thus ultimately oil for heating and electricity for motive power.

Table 27: Energy sources' shares of industrial demand（\%)

\begin{tabular}{|c|c|c|}
\hline FY & 1990 & 2010 \\
\hline Coal & 25.5 & 22.8 \\
\hline Oil & 49.5 & 41.2 \\
\hline Gas & 2.9 & 11.3 \\
\hline Electricity & 20.3 & 23.0 \\
\hline
\end{tabular}

Note: 'Gas' is the total for energy sources classified as city gas or natural gas for statistical purposes.

Source: 'EDMC Handbook of Energy and Economic Statistics in Japan, 2011' Energy Conservation Center, Japan. 
Table 28: Average annual growth rates of GDP and individual energy sources in industry

\begin{tabular}{|l|c|c|c|}
\hline & $1990 / 2000$ & $2000 / 2010$ & $1990 / 2010$ \\
\hline Coal & -0.2 & -1.2 & -0.7 \\
\hline Oil & 1.1 & -3.1 & -1.0 \\
\hline Gas & 7.8 & 6.2 & 7.0 \\
\hline Electricity & 1.1 & -0.1 & 0.5 \\
\hline Total & 1.0 & -1.3 & -0.1 \\
\hline \multicolumn{4}{|l}{} \\
\hline GDP & 1.1 & 0.6 & 0.9 \\
\hline
\end{tabular}

Source: EDMC Handbook of Energy and Economic Statistics in Japan, 2011; Energy Conservation Center, Japan

Figure 20: Trends in GDP and energy consumption by source in industry $(1990=$ 100)

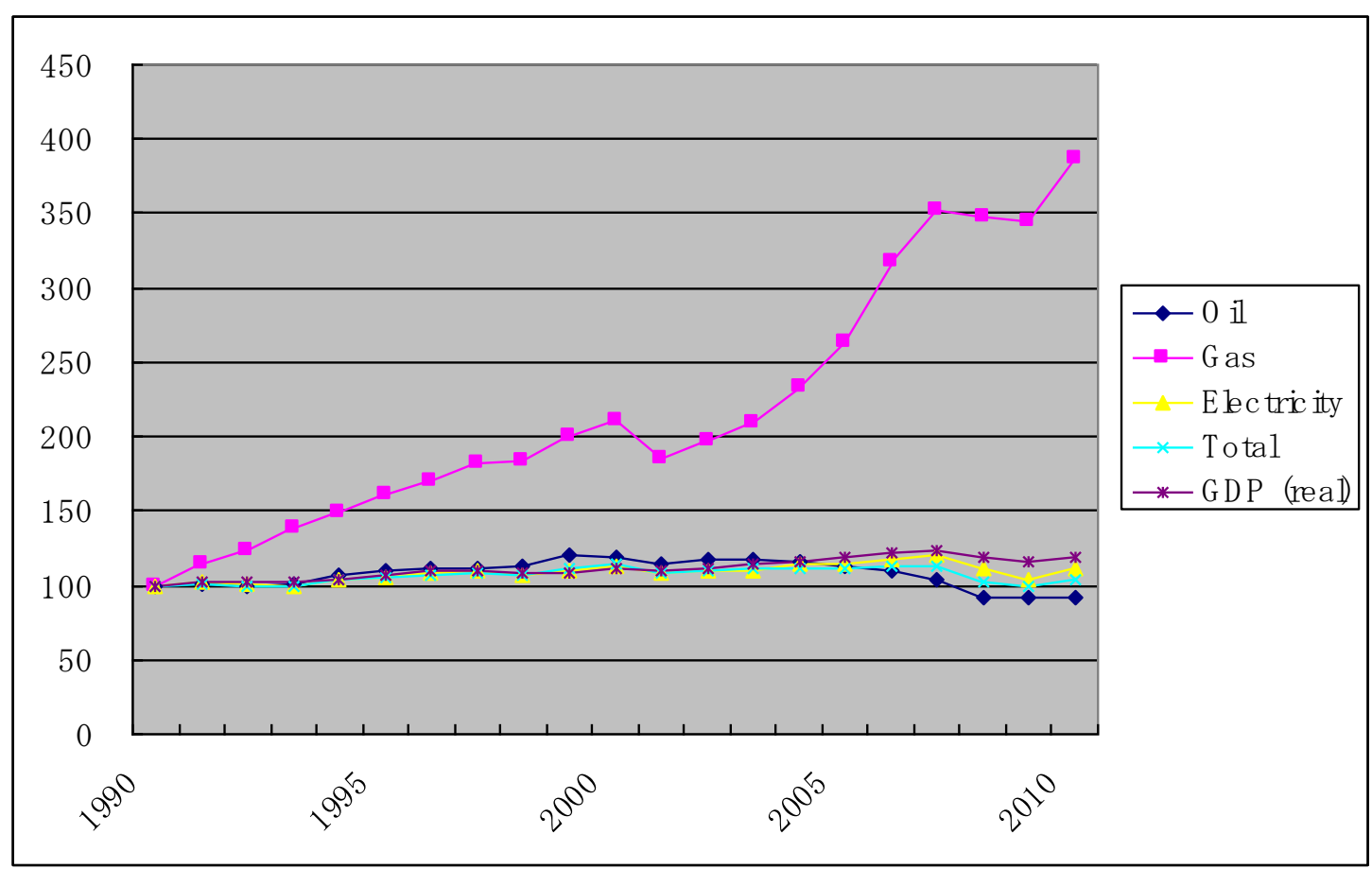

Source: 'EDMC Handbook of Energy and Economic Statistics in Japan 2011'Energy Conservation Center, Japan.

Taking into account these conditions, projections were calculated following the approach outlined in Figure 21. 
Figure 21: Approach for estimating industrial demand

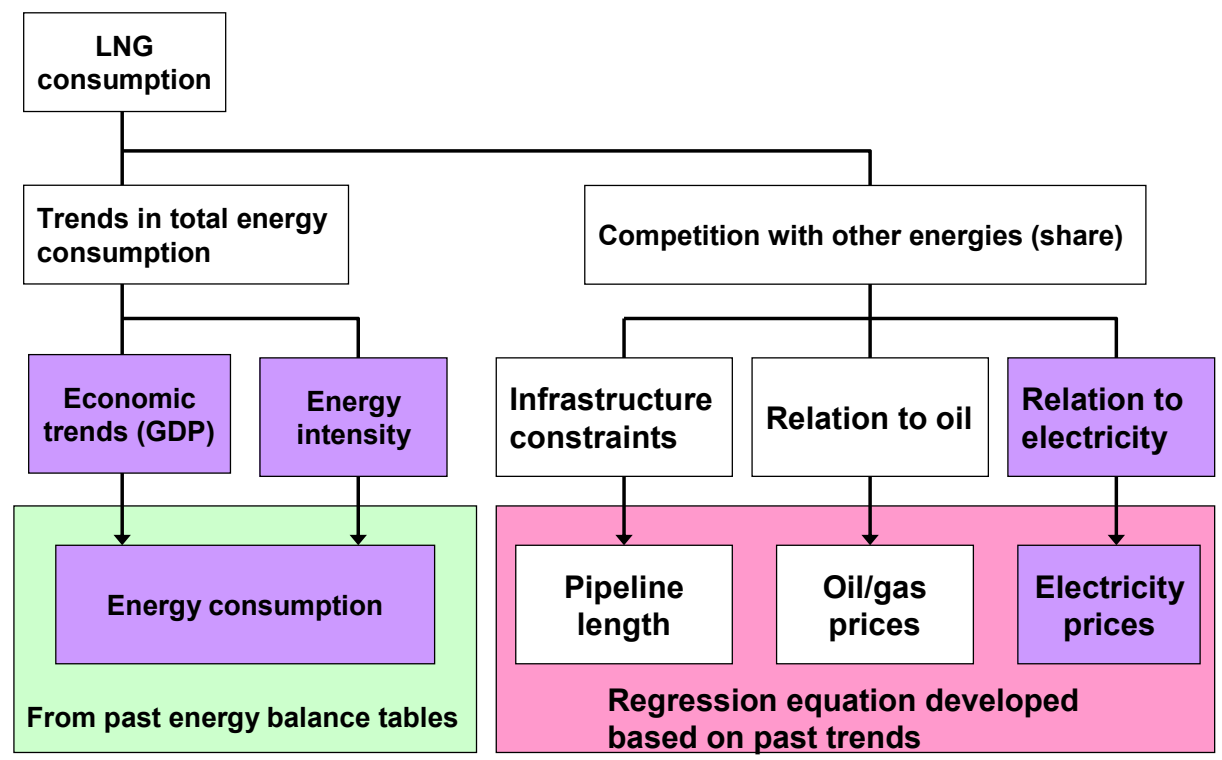

The premises for calculation of projections are shown in Table 29. 
Table 29: Past trends and assumptions (Industrial sector)

\begin{tabular}{|c|c|c|}
\hline Factor & Pre-11 March trends & Premises for projections \\
\hline $\begin{array}{l}\text { Economic } \\
\text { trends }\end{array}$ & \multirow{3}{*}{\multicolumn{2}{|c|}{ As for the commercial sector (see Table 26). }} \\
\hline $\begin{array}{l}\text { Oil/LNG price } \\
\text { ratio }\end{array}$ & & \\
\hline $\begin{array}{l}\text { Electricity/city } \\
\text { gas price ratio }\end{array}$ & & \\
\hline $\begin{array}{l}\text { Energy } \\
\text { consumption } \\
\text { per unit GDP }\end{array}$ & $\begin{array}{l}\text { Industrial energy consumption per unit GDP } \\
\text { was falling and the rate of decline was } \\
\text { particularly steep following the Lehman crisis. }\end{array}$ & $\begin{array}{l}\text { - The GHG reduction target in } 2020 \text { is assumed to } \\
\text { be a realistic }-5 \% \text {. } \\
\text { - Assuming that } \mathrm{CO}_{2} \text { reductions will be achieved } \\
\text { by energy conservation if nuclear power is cut, } \\
\text { unit total energy consumption will be reduced } \\
\text { approximately } 6 \% \text { by } 2020 .^{73} \\
\text { - From FY } 2012 \text { to FY } 2020 \text {, the downward trend } \\
\text { was assumed to be almost constant. }\end{array}$ \\
\hline Pipeline length & $\begin{array}{l}\text { - City gas service areas were limited to urban } \\
\text { areas and the high-pressure trunk gas } \\
\text { pipeline network was also insufficient. } \\
\text { There was thus still scope for extension of } \\
\text { pipelines, and the trend in pipeline length } \\
\text { was upward. } \\
\text { - However, the national average rate of } \\
\text { growth in medium- and high-pressure } \\
\text { pipeline length over the past five years has } \\
\text { declined by around } 0.05 \% \text { annually. The } \\
\text { rate of increase in FY } 2009 \text { was } 1.16 \% \text {. }\end{array}$ & $\begin{array}{l}\text { - The rates of growth in pipeline length announced } \\
\text { by the three leading utilities in their supply plans } \\
\text { was adopted for } 2010 \text {, and growth was set at } \\
-0.05 \% \text { from FY } 2011 \text { onward. }\end{array}$ \\
\hline
\end{tabular}

Estimating total energy consumption in the industrial sector based on the above assumptions yields an annual decline of $0.7 \%$ for the period FY 2010-20. City gas demand, on the other hand, is forecast to grow by a rate of $2.2 \%$, and its share will increase by 3.5 percentage points.

73 The increase in $\mathrm{CO}_{2}$ emissions is calculated assuming that the decrease in nuclear power output is replaced by thermal power generation using natural gas. A $6.2 \%$ reduction in unit energy consumption will be required if a reduction commensurate with this increase is to be achieved through energy conservation. 


\subsection{Estimation Results}

\subsubsection{LNG demand outlook for the city gas sector}

In the residential sector, LNG demand under the base scenario is estimated to follow an upward trend until FY 2015 and then go into decline. This is due to a combination of the peaking of growth in the number of households, rising electrification, and further energy conservation, leaving few grounds to expect major growth in this sector.

In the commercial sector, the tailing off of growth in total floor area and enhanced action to save energy similarly mean that major growth is unlikely. As we will see in the next section, market growth depends primarily on an improvement in LNG's competitiveness against electricity. Under the base scenario it is estimated that demand will grow by an annual average of around $0.42 \%$ /year up to FY 2020.

The market with greatest growth potential is the industrial sector. Growth during the past 10 years has been substantial, and relatively high growth is expected in this sector under the base scenario (averaging around $2.85 \%$ per year up to FY 2020). As shown in Figure 22, while total energy demand in the industrial sector is on the decline, demand for city gas is growing. In short, the potential for growth in LNG's market share will depend in particular on its competitiveness against energy sources such as oil, and the events of 11 March have placed the focus firmly on competition with electricity.

Table 30: Annual Growth Rate by sector

\begin{tabular}{|l|c|}
\hline & $\begin{array}{c}\text { Growth Rate (\%/Year) } \\
\text { FY2011/2020 }\end{array}$ \\
\hline Residential & -0.57 \\
\hline Commercial & 0.42 \\
\hline Industrial & 2.85 \\
\hline Total & 1.60 \\
\hline
\end{tabular}


Figure 22: Outlook for demand trends by sector $(2010=100)$

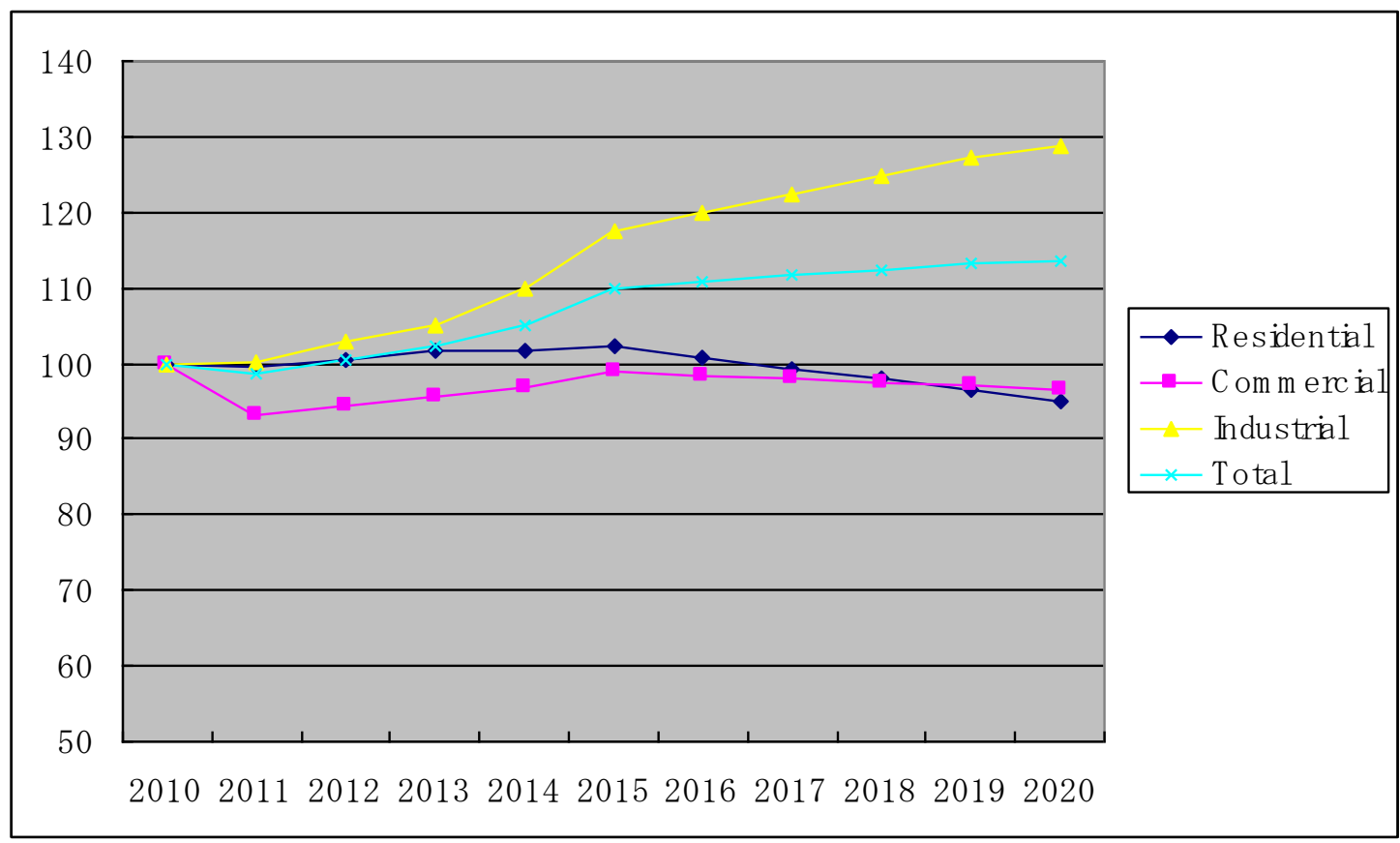

Figure 23: Trends in total energy consumption and city gas (Industrial sector)

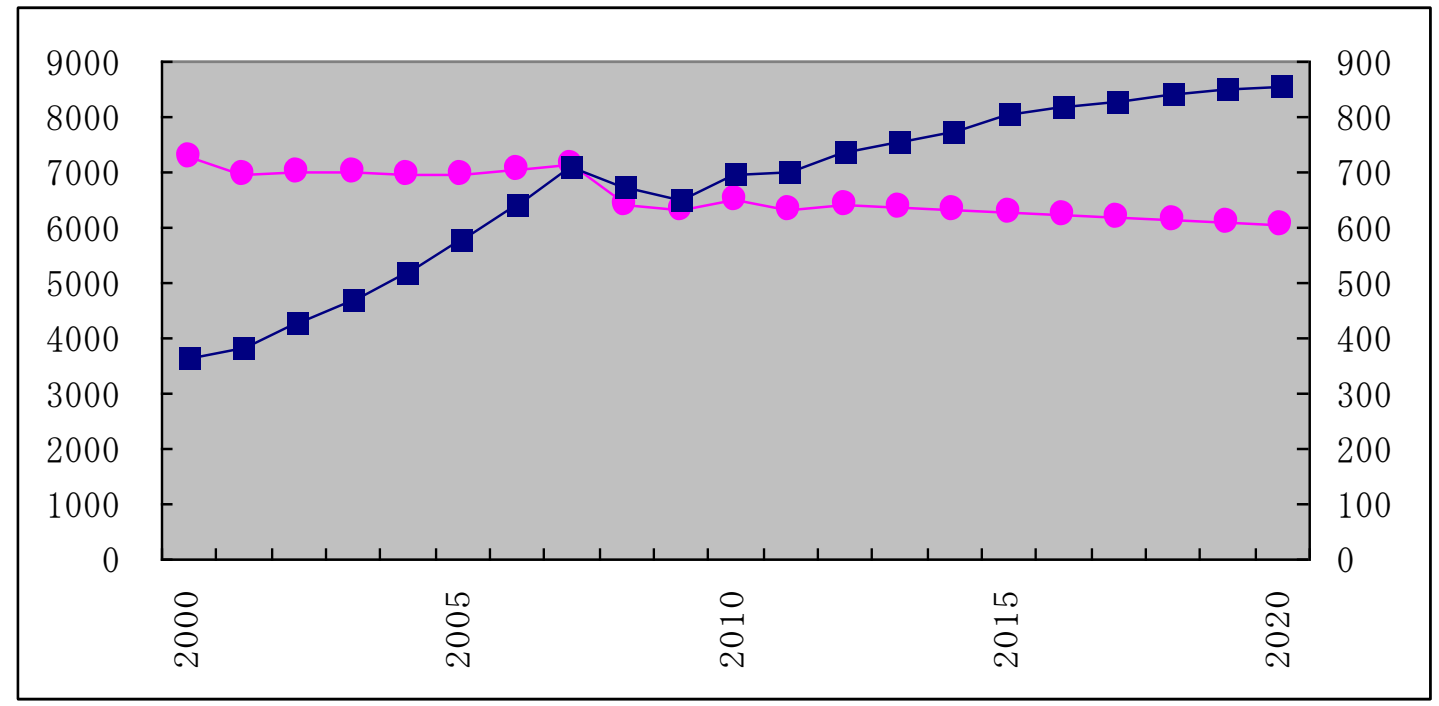

Source: Actual consumption; 'EDMC Handbook of Energy and Economic Statistics in Japan, 2011'Energy Conservation Center, Japan.

\subsubsection{Uncertainty of gas demand in the industrial sector}

Although gas demand in the industrial sector is one of key drivers of future LNG demand, it is increasingly uncertain after 11 March. Therefore, we would like to focus on this point in this section.

Firstly, the trends of gas demand in the sector before 11 March can be summarized as follows; 
- As shown in Figure 20, the growth rate of gas demand in the sector was very high in comparison with other sectors.

- After 2004 when oil prices started to increase and, at around the same period, prices for LNG have risen due to its tight supply/demand balance, city gas gradually lost its price competitiveness against electricity. As a result, both adoption rates and utilization rates of gas facilities competing with electricity such as co-generation and/or air conditioning started to stagnate, particularly, in large urban areas.

- On the other hand, in the rural areas, gas demand in the sector increased steadily with new construction of gas supply infrastructure as gas' price competitiveness against oil products increased further due mainly to S-curve effects of LNG pricing formula.

- Consequently, the signs of decrease in demand competing with electricity were offset by the increase in demand competing with oil products in the gas sales statistics. One important fact hidden in this trend is that gas demand in the sector is heavily dependent on price competitiveness against competing fuels.

- After 2008, the gas demand decreased substantially due to the economic crisis in the developed countries and then resumed around 2010 as described in the previous sections.

The future gas demand in the sector can be considered as follows by taking account of the above trends;

- Fundamental preconditions to predict the future gas demand are how Japan's electric power industry will be re-constructed and how electricity's price competitiveness against other fuels will change or will not change. For example, the worst scenario for Japan would be that electricity rates will increase substantially and energy demand in the sector as a whole will decline further due to manufacturing companies' relocation abroad.

- Another crucial precondition is whether Japan's LNG procurement practices will change or not particularly in terms of pricing. According to the financial results in FY2011, 8 EPCOs out of $10^{74}$ suffered from huge net losses due to high fuel costs. Therefore, requirements for reducing LNG procurement costs will be essential for both EPCOs and final consumers as electricity rates should not be raised further from the current considerably high level. For example, if LNG pricing moves away from the high JCC-linked levels of the recent past, price competitiveness of city gas is likely to increase substantially against oil products and probably against electricity in some degree as well. Conversely, if the existing pricing are not changed and LNG prices stay at high levels, the

${ }^{74}$ Okinawa EP and Chugoku EP turned profits in FY 2011. 
growth of gas demand in the industrial sector will be limited. Related to this point, it is still uncertain how much gas demand for private power generation will be added because the economy of such power generation is highly dependent on fuel costs. Under Japan's energy market situation immediately before 11 March, such power generation fueled by gas was not competitive with networked power supplies.

In summary, there are a lot of uncertainties surrounding gas demand in the industrial sector and the above mentioned possible changes can be regarded as something like an energy market "paradigm shift". So, the above preconditions can not be completely included in the quantitative analysis ${ }^{75}$ in this report but are examined qualitatively in the conclusions.

${ }^{75}$ Influences on gas demand by increase in electricity rates are examined by the model. 


\section{Conclusions}

Working on the basis of the above estimates, we examine lastly the question of how to regard total medium- to long-term LNG demand in Japan.

\subsection{Comparison of our Estimates against Actual Demand}

Before considering overall trends in LNG demand in Japan, we first verify the reliability of the estimates obtained by the model by comparing them against data on actual demand since 11 March. Data on actual imports up to December 2011 have already been published in Trade Statistics of Japan, which shows that imports grew 7.9 $\mathrm{mt}(15.5 \%)$ from a year earlier to $59.2 \mathrm{mt}$. Based on past consumption by the electricity and city gas sectors to date, imports for the period from January to March 2012 are estimated to have come to around 21.3-21.5 mt. ${ }^{76}$ Japan's total LNG consumption in FY 2011 may therefore be estimated to have been in the region of 80.5-80.9 $\mathrm{mt}$.

The estimation model, on the other hand, yields a figure of $80.14 \mathrm{mt}$, which coincides almost exactly with the above. We can conclude, therefore, that factors having an impact on future outlook, such as relations between lower nuclear capacity factors and extra LNG demand, are accurately reflected in the model, indicating that our estimation method is highly reliable.

Table 31: Comparison of estimates by model against actual demand

Source: Actual consumption is estimated based on data of 'Trade Statistics of Japan' and data published by METI.

76 LNG demand in the power generation sector was estimated taking into consideration nuclear load factors, etc. In the case of the city gas sector, estimates were made based on trends in FY 2011. 


\subsection{Outlook for LNG Demand in Japan after Fukushima}

In this paper, LNG demand was estimated divided into two categories: demand for electricity generation and demand for city gas. First of all, we examine how the factors that govern demand in these two sectors are interlinked, and how demand as a whole may change.

One thing that is evident is that non-generation LNG demand is more complex than generation demand owing to the wider range of significant variables to consider. Hence, demand relations in these two sectors were considered to be as shown in the tables below. Judging from our estimates thus far, the largest contributor to fluctuations in LNG demand is the load factor for nuclear power plants ${ }^{77}$, as a result of which annual demand during the period under consideration could fluctuate by up to 9-11 $\mathrm{mt}$. Alongside this, large differences could arise affecting the Japanese economy, industry, people's lives, energy prices, energy conservation policy, the structure of the electricity and energy markets, and so forth depending on whether there is an expansion of or withdrawal from nuclear power. Focusing on the nuclear load factor, therefore, we set forth the possible impacts of a number of factors on LNG demand in Table 34. Most of these factors have already been incorporated into the assumptions of our model for estimating LNG demand in the city gas sector. For ease of comprehension, the base scenario is positioned nearest the center of the table.

\section{$\underline{\text { Improved load factor scenario (Renuclearization) }}$}

- In the base scenario, the nuclear load factor is comparatively high as it is assumed that existing power plants will come back online from 2013. Even if plants are not decommissioned after 40 years of service, therefore, there will be relatively little scope for the load factor to be much higher than in the base scenario. Hence, the range of fluctuation in LNG demand will also be small (approximately $3 \mathrm{mt} /$ year less than in the base scenario).

- In order for nuclear power to be revived, the improved load factor scenario entails a return of energy policy and conditions in the energy market to basically what they were before $3 / 11$. Specifically, the constraints on electricity supply capacity are small and the margin of electricity price increases will be narrow. It is envisaged that the negative impact on the economy will also consequently be small, and energy conservation will not have to be practiced as rigorously as under the reduced load factor scenario. These factors are likely to push up LNG demand moderately.

- As regards power policy, on the other hand, it is more likely that deregulation of

77 As city gas demand basically accounts for around $30 \%$ of the total, the margin of fluctuation in demand is small. 
the electricity market will not make progress further and the revival of nuclear power is expected to result in relatively less of a transition to distributed generation and fewer opportunities for new entrants. There is also unlikely to be a large increase in the load factor for self-generators. These factors will make LNG demand more sluggish.

- In the improved load factor scenario, therefore, growth in LNG demand will on balance be constrained, and so LNG demand will probably be around $80 \mathrm{mt}$ in 2020.

\section{$\underline{\text { Reduced load factor scenario (Denuclearization) }}$}

- The outlook for LNG demand under the Denuclearization scenario is shown in Table 33, but it should be noted that these figures may be unrealistic particularly from the long term point of view for the following reasons.

- While a marked decline in the load factor of nuclear power plants would mean major changes for Japan's energy supply structure, a critical concern over the economics of power generation has become apparent since 11 March. As explained earlier, electric power utilities have substituted the lost nuclear capacities mainly with thermal plants fuelled by LNG and oil but this led to huge financial losses in FY2011 (see Table 35) due to the burden of massive fuel $\operatorname{costs}^{78}$.

- Therefore, it is highly likely that under the denuclearization scenario, electricity rates will have to be increased substantially. ${ }^{79}$ The adverse impact on the Japanese economy as a whole is thus certain and the risk of economic downturn and deindustrialization will grow further. At the same time, energy conservation is expected to be enhanced greatly. In combination, these developments will surely cause LNG demand to decrease. In sum, if oil prices remain high and the pricing of fuels is unchanged in the scenario, Japan's economy will no longer be sustainable at all.

- Of course, in order to break the impasse over this situation, countermeasures such as further liberalization of the electricity market might be implemented and this could lead to more new entrants, a move to distributed generation, and a rise in the load factor of self-generators. These are factors which may increase LNG demand. However, it is extremely difficult for Japan to solve the fundamental question, i.e. how to maintain appropriate economic growth, unless the lost base load power generation capacities are substituted by something at around the same level of

\footnotetext{
${ }^{78}$ For example, it is reported that the additional fuel costs of 9 EPCOs during April to December in 2011 in comparison with the same period of the previous year was 1430 billion Yen. Mainichi Shinbun, $3^{\text {rd }}$ April, 2012

79 According to IEEJ estimates, electricity rates for residential customers are to increase by around $18 \%$ and Fujitsu Research Institute prospects by 35\% by 2020. Nihon Keizai Shinbun, 27 June 2011.

TEPCO, whose situation is quite different from other EPCOs, has already increased electricity rates for liberalized customers by 17\% (average) from 1 April 2012.
} 
costs as existing nuclear power generation.

- Therefore, under the scenario, Japan can no longer regard LNG as a fuel for middle-peak load generation capacities nor as a fuel for substitution with oil in the power generation sector. In other words, if Japan will continue to consume natural gas in the sector, the current LNG pricing should be rationally revised.

- Given the above, other energy sources such as city gas are projected to become more competitive, increasing LNG demand beyond the generation sector. However, a sensitivity analysis of the city gas sector indicates that the impacts on LNG demand by electricity rate increases and fluctuations in unit gas consumption will be smaller than those in the power generation sector (for example, by substitution for the lost nuclear power capacity). ${ }^{80}$

- Uncertainty is created by the possibility of a protracted and considerable decline in the nuclear capacity factor that might cause the energy market to diverge considerably from trends prior to 11 March. In particular, further deregulation leading to fundamental changes to the structure of the energy market as a result of unbundling, etc. would increase the probability of changes occurring that cannot be accommodated by the present estimation model. The effect of many such changes would be to push up LNG demand, but it is highly dependent on the economics of LNG.

- In conclusion, the high level of LNG demand shown in Table 34, is unlikely to continue for the long term and if LNG prices are not reduced, it is highly likely that the demand will start to decrease as a result of various negative impacts on Japan's economy.

Table 32: Load factors of nuclear plants (\%)

\begin{tabular}{|l|c|c|c|c|c|c|c|c|c|c|}
\hline \multicolumn{1}{|c|}{ Fiscal Year } & 2011 & 2012 & 2013 & 2014 & 2015 & 2016 & 2017 & 2018 & 2019 & 2020 \\
\hline Base Scenario & \multirow{4}{*}{24} & \multirow{3}{*}{0} & 52 & 53 & 51 & 47 & 47 & 46 & 45 & 41 \\
\cline { 1 - 10 } Renuclearization & & 53 & 54 & 54 & 53 & 54 & 54 & 54 & 52 \\
\cline { 1 - 9 } Denuclearization & & & 0 & 0 & 0 & 0 & 0 & 0 & 0 & 0 \\
\hline
\end{tabular}

Note: Load factors were calculated by adding new capacity to existing nuclear capacity immediately before 11 March to obtain total power generating capacity. Note, therefore, that plants with decommissioned or inoperable reactors, such as Fukushima I, are also included in existing capacity

80 Sensitivity analysis by the model indicates that even if electricity rates rise by around $10 \%$, the increase in LNG demand in the city gas sector will be less than $1 \mathrm{mt}$. 
Table 33: LNG demand outlook for Japan according to estimation model

(million tons)

\begin{tabular}{|c|c|c|c|c|c|c|c|c|c|c|c|c|}
\hline Fiscal Year & 2009 & 2010 & 2011 & 2012 & 2013 & 2014 & 2015 & 2016 & 2017 & 2018 & 2019 & 2020 \\
\hline Base Scenario & \multirow{3}{*}{66.4} & \multirow{3}{*}{69.8} & \multirow{3}{*}{80.1} & \multirow{3}{*}{82.4} & 73.6 & 74.8 & 76.8 & 78.3 & 79.3 & 79.9 & 80.5 & 81.2 \\
\hline Renuclearization & & & & & 73.3 & 74.4 & 75.5 & 76.1 & 77.0 & 77.7 & 77.8 & 78.1 \\
\hline Denuclearization & & & & & 83.3 & 85.0 & 84.8 & 85.8 & 87.6 & 88.2 & 88.3 & 88.7 \\
\hline
\end{tabular}

Note: Figures in the table were obtained using the city gas demand under the base scenario for all scenarios.

Table 34: Contributors to change in LNG demand

\begin{tabular}{|c|c|c|c|}
\hline \multicolumn{3}{|c|}{ Base scenario } & \\
\hline \multirow{2}{*}{\multicolumn{2}{|c|}{ Lower nuclear load factor }} & \multicolumn{2}{|c|}{ Higher nuclear load factor } \\
\hline & & Lower LN & demand \\
\hline \multirow[t]{3}{*}{$\begin{array}{c}\text { Contributors to LNG } \\
\text { demand growth }\end{array}$} & $\begin{array}{l}\text { Contributors to LNG } \\
\text { demand shrinkage }\end{array}$ & $\begin{array}{l}\text { Contributors to LNG } \\
\text { demand growth }\end{array}$ & $\begin{array}{l}\text { Contributors to LNG } \\
\text { demand shrinkage }\end{array}$ \\
\hline & $\begin{array}{l}\text { - Economic downturn } \\
\text { - Lower energy demand } \\
\text { - Lower electricity } \\
\text { demand } \\
\text { - Further } \\
\text { deindustrialization }\end{array}$ & $\begin{array}{l}\text { - Economic upturn } \\
\text { - Higher energy demand } \\
\text { - Higher electricity } \\
\text { demand } \\
\text { - No further } \\
\text { deindustrialization }\end{array}$ & \\
\hline & $\begin{array}{l}\text { - Further energy } \\
\text { conservation } \\
\text { - Decreased unit gas } \\
\text { consumption }\end{array}$ & $\begin{array}{l}\text { - No further energy } \\
\text { conservation } \\
\text { - Unchanged unit gas } \\
\text { consumption }\end{array}$ & \\
\hline $\begin{array}{l}\text { - Further electricity } \\
\text { deregulation } \\
\text { - Increased entries }\end{array}$ & & & $\begin{array}{l}\text { - Stagnation of electricity } \\
\text { deregulation } \\
\text { - Sluggish entries }\end{array}$ \\
\hline - Higher electricity rates & & & - Stable electricity rates \\
\hline $\begin{array}{l}\text { More rapid } \\
\text { development of natural } \\
\text { gas infrastructure }\end{array}$ & & & $\begin{array}{l}\text { - Slower development of } \\
\text { natural gas } \\
\text { infrastructure }\end{array}$ \\
\hline $\begin{array}{l}\text { More rapid spread of } \\
\text { distributed generation } \\
\text { - Higher self-generated } \\
\text { capacity factor }\end{array}$ & & & $\begin{array}{l}\text { - Slower spread of } \\
\text { distributed generation } \\
\text { - Lower self-generated } \\
\text { capacity factor }\end{array}$ \\
\hline $\begin{array}{l}\text { - Less focus on } \\
\text { all-electric homes }\end{array}$ & & & $\begin{array}{l}\text { - More focus on } \\
\text { all-electric homes }\end{array}$ \\
\hline
\end{tabular}


Table 35: Outlook for financial result of EPCOs in FY 2011

\begin{tabular}{|c|c|c|c|}
\hline \multirow{2}{*}{ EPCO } & \multirow{2}{*}{$\begin{array}{c}\text { Net Profit/Loss } \\
\text { (million US \$) }\end{array}$} & \multicolumn{2}{|c|}{ Fuel costs } \\
\cline { 3 - 4 } & & (billion US \$) & $(\%)$ \\
\hline Hokkaido & -900 & 2.1 & $108 \%$ \\
\hline Tohoku & $-2,899$ & 6.4 & $75 \%$ \\
\hline Tokyo & $-9,770$ & 28.6 & $54 \%$ \\
\hline Chubu & $-1,151$ & 13.0 & $53 \%$ \\
\hline Hokuriku & -65 & 1.8 & $73 \%$ \\
\hline Kansai & $-3,028$ & 9.7 & $101 \%$ \\
\hline Chugoku & 30 & 4.0 & $26 \%$ \\
\hline Shikoku & -116 & 1.6 & $71 \%$ \\
\hline Kyushu & $-2,041$ & 6.5 & $83 \%$ \\
\hline Okinawa & 87 & 0.6 & $19 \%$ \\
\hline Total & $-19,853$ & 74.4 & $63 \%$ \\
\hline
\end{tabular}

Note: Exchange rate $80 \mathrm{JPY} / \mathrm{US} \$$

Source: Each company's financial result for FY2011

Allowing for the fact that long-term energy policy has yet to be established, Japanese LNG demand circa FY 2020 is expected to decline slightly from FY 2011 to around 78 mt under the optimistic scenario (which assumes that nuclear power plants will come back online and that reactors will not be decommissioned after 40 years of service). In the extreme case that the nuclear capacity factor falls to zero, on the other hand, LNG would increase by only around $9 \mathrm{mt}$ compared with FY 2011. Assuming, therefore, that a certain amount of nuclear power can be brought back online, the future impact on the international LNG market is unlikely to be that great. 


\section{Appendix 1. Situation at Fukushima I NPS}

On 11 March, Units 1 to 3 at Fukushima I NPS were in operation, but all cores were scrammed as soon as the earthquake struck. Although this was immediately followed by the loss of all offsite power due to collapse of power line towers, etc., activation of the emergency diesel generators allowed reactor core cooling to commence. However, the site was then inundated by the ensuing tsunami, which ranged in height from 11.5 to 17 metres. The tsunami submerged the seawater cooling pumps, emergency diesel generators, and electricity supply facilities (switchboard), causing all the emergency diesel generators except one supplying Unit 6 to shut down. This was followed by the failure of the emergency batteries and, ultimately, the loss of all power. It is at this time that the fuel rods in Units 1-3 were inferred to be exposed. The next day (12 March) venting work was carried out on Unit 1 to release an abnormal rise in pressure in the containment vessel. However, this was soon followed by a hydrogen explosion that blew away part of the reactor building. On $14 \mathrm{March}$, it is thought that a hydrogen explosion occurred in the Unit 3 reactor building, followed by another on 15 March in Unit 4, which was offline when the earthquake struck. Although Unit 2 experienced no such explosion, its containment vessel appears to have suffered some form of damage when Unit 4's reactor building exploded.

Units 5 and 6 were offline for regular inspection at the time of the earthquake. Although both suffered a temporary loss of power, one emergency diesel generator started up, enabling a state of cold shutdown to be maintained.

On 11 March, the government ordered residents to evacuate from within a $3 \mathrm{~km}$ radius of Fukushima I NPS, and this was extended to residents within $20 \mathrm{~km}$ the following day. However, the delay in ordering evacuation combined with the fact that the evacuation area did not coincide with the area subjected to fallout stored up problems for the future.

It is believed that four hours after the earthquake struck, the Unit 1 reactor core began to melt. After 16 hours, the majority of the fuel had burned through, leaking from the pressure vessel and penetrating the concrete of the containment vessel. However, it was more than two months later on 12 May that it was announced that a core meltdown may have occurred at Unit 1, followed by a similar announcement concerning Units 2 and 3 on 24 May.

Hazardous work continues at the site as workers battle to deal with contaminated water. On 16 December, however, the government was able to declare that the accident had 
been contained with the attainment of a state of cold shutdown at Fukushima I NPS. On 21 December, it also approved a roadmap for decommissioning Units 1 through 4, a process which will take 30 to 40 years ${ }^{81}$.

81 'Medium- and long-term road map for decommissioning of nuclear reactors 1 through 4 of Fukushima NPSs' Cabinet Secretariat www.cas.go.jp/jp/genpatsujiko/pdf/111221_01a.pdf 


\section{Appendix 2. Comparison of Fuel consumption by TEPCO: Shut Down of Kashiwazaki-Kariwa (2007) and Fukushima (2011)}

There were marked differences in TEPCO's fuel consumption in particular between the situation following Kashiwazaki-Kariwa NPS's shutdown in 2007 due to Niigata-ken Chuetsu-oki earthquake and that following the Fukushima crisis.

In the summer of 2007, seven reactors at Kashiwazaki-Kariwa NPS were shut down, but demand increased from the previous year. The amount of additional power needed therefore consisted of that lost due to the nuclear shutdown plus the increase in demand. A comparison of the loss in nuclear power output and the increase in thermal power output shows that lost output was almost entirely compensated for by thermal power in 2007. In 2011, on the other hand, thermal power compensated for only around half of the lost output. Considering that there was no major difference in output lost, the impact on thermal power generation in 2011 can be seen to have been far less than anticipated.

Figure 24: Lost nuclear power and thermal fuel power output in 2007 and 2011

2007

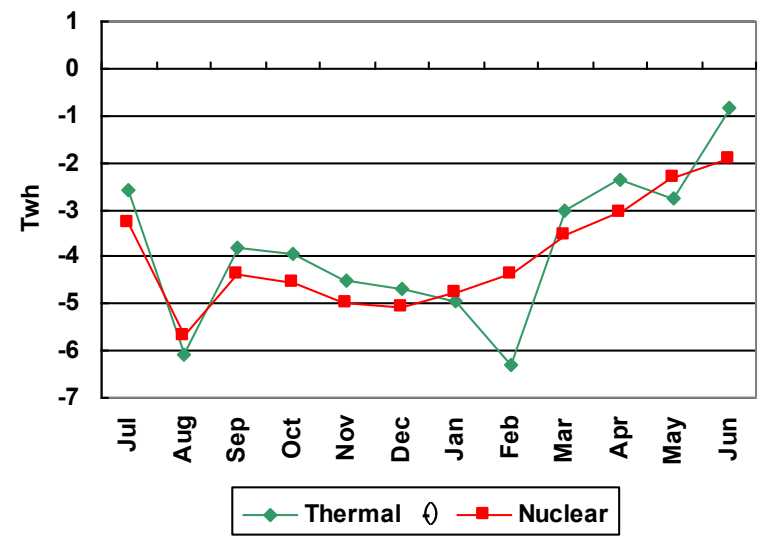

2011

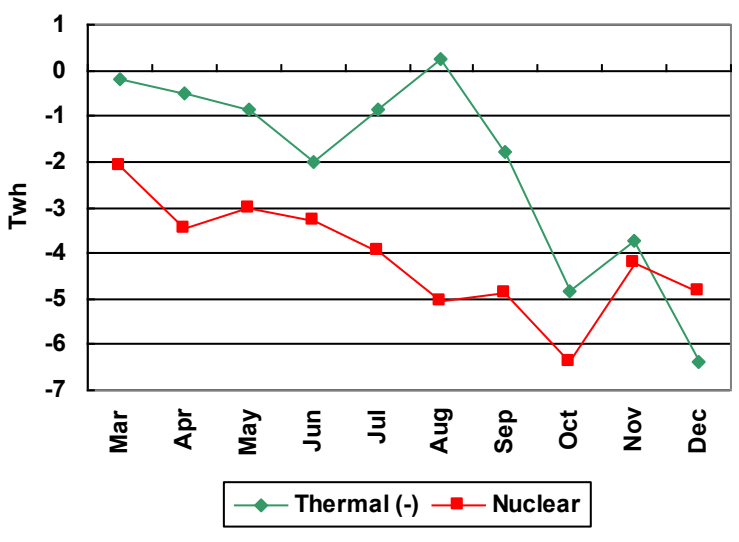

Note: The green line indicates the increase in generated power negatively.

Source: Statistics of Electricity, METI Web site

From the point of view of fuel consumption patterns, there was considerable consumption of heavy oil following the Kashiwazaki-Kariwa shutdown, where it was first used as a backup, and LNG consumption too grew strongly (mainly during the summer). Following the 11 March earthquake, on the other hand, almost the only backup fuel used was LNG, and there was practically no increase in consumption of other fuels (or even a decrease).

There are several possible reasons for this. Firstly, damage in the affected regions hit mostly coal- and oil-fired thermal power generation facilities, and LNG-fired capacity was left unscathed. Secondly, although some oil-fired thermal power capacity was 
rapidly brought back online, the damage to refineries, shortage of coastal tankers, and damage to port facilities impeded procurement of heavy oil supplies. Thirdly, there was access from an early stage to LNG procurements. And fourthly, the large drop in demand ultimately made it unnecessary to increase use of oil-fired capacity to meet peak load.

The supply of heavy oil in particular was affected by the limited scope for procurements due, among other things, to the drive for efficiency in the face of the long-term decline in demand for heavy oil for power generation purchases, making it harder to respond quickly and flexibly in emergency situations.

Figure 25: Year on year increase of fuel consumption in 2007and 2011 - TEPCO
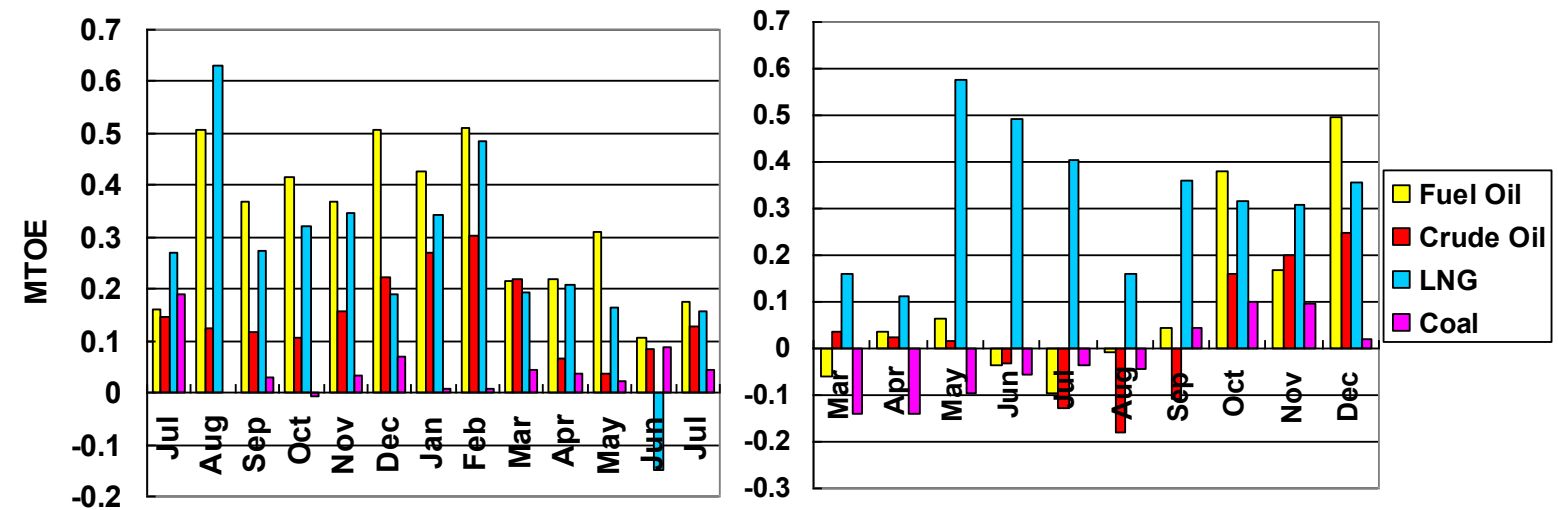

Source: Statistics of Electricity, METI Web site 


\section{Appendix 3. Damage and Restoration of Thermal Power Capacity ${ }^{82}$}

By the end of July, TEPCO had brought its own damaged thermal power plants back online $(+11.8 \mathrm{GW})$ and also benefited from the restoration of supplies from wholesalers such as Kashima Kyodo Electric Power, Hitachi Kyodo Electric Power, IPPs, and other sources $(+3.5 \mathrm{GW})$; the reactivation of the mothballed Yokosuka Thermal Power Station $(+0.9 \mathrm{GW})$; and installation of emergency power units $(+1.3$ GW). Kashima Kyodo Thermal Electric Power, which was the first to recover from the earthquake, reactivated its No. 1 unit on April 16 while still carrying out repairs. Its No. 3 unit then came back online on 7 June, followed by its No. 4 unit on 20 July, enabling it to sustain the supply of electricity in the summer. Further capacity was provided by the use of pumped-storage hydro-power generation (+6 GW), ramping up of output, and acceleration of regular inspections.

Tohoku EPCO similarly installed emergency power units (in Higashi-Niigata), reactivated mothballed capacity (at Higashi-Niigata), expanded its purchasing of surplus electricity from self-generators, resumed operations at the Kamaishi Works Thermal Power Plant (136 MW in July 2011), and commenced commercial operation at the newly built Niigata 5. However, supply capacity could not be increased in time and shortages were further compounded by the suspension of operations at 29 hydroelectric plants due to flooding following torrential rain in July and a decline in supply capacity of $1 \mathrm{GW}$, necessitating increased power interchange from TEPCO and other suppliers. According to METI figures, Tohoku EPCO's reserve margin was negative for nine days in August, and rolling blackouts were considered a possibility.

In addition, the following thermal plants recovered by the end of 2011.

Joban Joint Power's Nakoso Power Plant had three units in operation at the time of the earthquake (Nos. 7-9), and these were damaged in the tsunami. Harbour facilities were also affected but were made temporarily usable on 20 May, allowing the unloading of $6,000 \mathrm{t}$ of coal for thermal power generation at Onahama, Fukushima, for the first time since the earthquake. Power generation was then recommenced at the No. 9 unit on 30 June, followed by No. 8 on 17 July, and the most heavily damaged No. 7 on 21 December.

Soma Kyodo Power's Shinchi Power Plant was also flooded by a tsunami of over 10 metres in height, causing coal receiving facilities and the seawall to collapse. On 30 November, however, an ocean-going coal carrier arrived at a makeshift terminal and $27,000 \mathrm{t}$ of coal was unloaded, enabling the plant to come back online in December. Overall, almost all power plants were back in operation by the end of 2011 .

${ }^{82}$ From the web sites of each company, The Denki Shinbun, METI, FEPC 
Table 36: Thermal power plants back in operation by the end of 2011

\begin{tabular}{|c|c|c|c|}
\hline Plant & Fuel & Capacity (GW) & Status \\
\hline Tohoku & & 11 & \\
\hline Hachinohe 3 & FO & 0.3 & Operation recommenced on $3 / 20$ \\
\hline Sendai 4 & LNG & 0.4 & Operation recommenced on $12 / 20$ \\
\hline Shin-Sendai 1 & FO & 0.4 & Operation recommenced on $12 / 27$ \\
\hline Haramachi 1 & Coal & 1 & Stop Operation \\
\hline Haramachi 12 & Coal & 1 & Stop Operation \\
\hline Tokyo & & 39 & \\
\hline Oi 1 & Crude & 0.4 & Operation recommenced on $3 / 12$ \\
\hline Oi 2 & Crude & 0.4 & Operation recommenced on $3 / 17$ \\
\hline Oi 3 & Crude & 0.4 & Operation recommenced on $3 / 13$ \\
\hline Hirono 1 & FO & 0.6 & Operation recommenced on $7 / 3$ \\
\hline Hirono 2 & FO & 0.6 & Operation recommenced on $7 / 11$ \\
\hline Hirono 3 & FO & 1 & Operation recommenced on $7 / 16$ \\
\hline Hirono 4 & FO & 1 & Operation recommenced on $7 / 14$ \\
\hline Hirono 5 & Coal & 0.6 & Operation recommenced on $6 / 15$ \\
\hline Hitachinaka 1 & Coal & 1 & Operation recommenced on $5 / 15$ \\
\hline Kashima 1 & FO & 0.6 & Operation recommenced on $5 / 16$ \\
\hline Kashima 2 & FO & 0.6 & Operation recommenced on $4 / 7$ \\
\hline Kashima 3 & FO & 0.6 & Operation recommenced on $4 / 6$ \\
\hline Kashima 4 & FO & 0.6 & Operation recommenced on $4 / 1$ \\
\hline Kashima 5 & FO & 1 & Operation recommenced on $4 / 8$ \\
\hline Kashima 6 & FO & 1 & Operation recommenced on $4 / 20$ \\
\hline Chiba 2-1 & LNG • & 1.4 & Stop Operation \\
\hline Yokohama 8 & LNG • & 1.4 & Operation recommenced on $3 / 11$ \\
\hline Goi 4 & LNG • & 0.3 & Stop Operation \\
\hline Wholesaler & & 8.2 & \\
\hline Kashima Kyodo 1 & FO & 0.4 & Operation recommenced on $4 / 16$ \\
\hline Kashima Kyodo 3 & FO & 0.4 & Operation recommenced on $6 / 7$ \\
\hline Kashima Kyodo 4 & FO & 0.4 & Operation recommenced on $7 / 20$ \\
\hline Soma 1 & Coal & 1 & Operation recommenced on $12 / 21$ \\
\hline Soma 2 & Coal & 1 & Operation recommenced on $12 / 19$ \\
\hline Nakoso 7 & Coal & 0.3 & Operation recommenced on $12 / 21$ \\
\hline Nakoso 8 & Coal & 0.6 & Operation recommenced on $7 / 17$ \\
\hline Nokoso 9 & $\mathrm{Coal} / \mathrm{FO}$ & 0.6 & Operation recommenced on $6 / 30$ \\
\hline Kimitsu 345 & $\mathrm{FO} / \mathrm{Gas}$ & 1.2 & Operation recommenced on $3 / 14$ \\
\hline Kamaishi & Coal & 0.1 & Operation recommenced on $7 / 1$ \\
\hline
\end{tabular}




\section{Appendix 4. Japanese Nuclear Power Plant}

\begin{tabular}{|c|c|c|c|c|c|c|}
\hline Company & Plant & \# & Start operation & Capacity $(\mathrm{GW})$ & Cap. Total & Type \\
\hline \multirow[t]{3}{*}{ Hokkaido } & Tomari & 1 & $1989 / 6$ & 0.579 & & PWR \\
\hline & Tomari & 2 & $1991 / 4$ & 0.579 & & PWR \\
\hline & Tomari & 3 & $2009 / 12$ & 0.912 & 2.07 & PWR \\
\hline \multirow[t]{4}{*}{ Tohoku } & Higashidori & & $1984 / 6$ & 1.1 & & BWR \\
\hline & Onagawa & 1 & $1995 / 7$ & 0.524 & & BWR \\
\hline & & 2 & $2002 / 1$ & 0.825 & & BWR \\
\hline & & 3 & $2005 / 12$ & 0.825 & 3.274 & BWR \\
\hline \multirow[t]{17}{*}{ Tokyo } & Fukushima1 & 1 & $1971 / 3$ & 0.46 & & BWR \\
\hline & & 2 & $1974 / 7$ & 0.784 & & BWR \\
\hline & & 3 & $1976 / 3$ & 0.784 & & BWR \\
\hline & & 4 & $1978 / 10$ & 0.784 & & BWR \\
\hline & & 5 & $1978 / 4$ & 0.784 & & BWR \\
\hline & & 6 & $1979 / 10$ & 1.1 & & BWR \\
\hline & Fukushima2 & 1 & $1982 / 4$ & 1.1 & & BWR \\
\hline & & 2 & $1984 / 2$ & 1.1 & & BWR \\
\hline & & 3 & $1985 / 6$ & 1.1 & & BWR \\
\hline & & 4 & $1987 / 8$ & 1.1 & & BWR \\
\hline & Kashiwazaki-karuwa & 1 & $1985 / 9$ & 1.1 & & BWR \\
\hline & & 2 & $1990 / 9$ & 1.1 & & BWR \\
\hline & & 3 & $1993 / 8$ & 1.1 & & BWR \\
\hline & & 4 & $1994 / 8$ & 1.1 & & BWR \\
\hline & & 5 & $1990 / 4$ & 1.1 & & ABWR \\
\hline & & 6 & $1996 / 11$ & 1.356 & & ABWR \\
\hline & & 7 & $1997 / 7$ & 1.356 & 17.308 & ABWR \\
\hline \multirow[t]{3}{*}{ Chubu } & Hamaoka & 3 & $1987 / 8$ & 1.1 & & BWR \\
\hline & & 4 & 1993/9 & 1.137 & & BWR \\
\hline & & 5 & $2005 / 1$ & 1.38 & 3.617 & ABWR \\
\hline \multirow[t]{2}{*}{ Hokuriku } & Shiga & 1 & $1993 / 7$ & 0.54 & & BWR \\
\hline & & 2 & $2006 / 3$ & 1.206 & 1.746 & ABWR \\
\hline \multirow[t]{6}{*}{ Kansai } & Mihama & 1 & $1970 / 11$ & 0.34 & & PWR \\
\hline & & 2 & $1972 / 7$ & 0.5 & & PWR \\
\hline & & 3 & $1976 / 12$ & 0.826 & & PWR \\
\hline & Takahama & 1 & $1974 / 11$ & 0.826 & & PWR \\
\hline & & 2 & $1975 / 11$ & 0.826 & & PWR \\
\hline & & 3 & $1985 / 1$ & 0.87 & & PWR \\
\hline
\end{tabular}




\begin{tabular}{|l|l|r|r|r|r|c|}
\hline & & 4 & $1985 / 6$ & 0.87 & & PWR \\
\hline & Oi & 1 & $1979 / 3$ & 1.175 & & PWR \\
\hline & & 2 & $1979 / 12$ & 1.175 & & PWR \\
\hline & & 3 & $1991 / 12$ & 1.18 & & PWR \\
\hline Chugoku & Shimane & 1 & $1993 / 2$ & 1.18 & 9.768 & PWR \\
\hline & & 2 & $1974 / 3$ & 0.46 & & BWR \\
\hline Shikoku & Ikata & 1 & $1989 / 2$ & 0.82 & 1.28 & BWR \\
\hline & & 2 & $1977 / 9$ & 0.566 & & PWR \\
\hline & & 3 & $1982 / 3$ & 0.566 & & PWR \\
\hline Kyusyu & Genkai & 1 & $1994 / 12$ & 0.89 & 2.022 & PWR \\
\hline & & 2 & $1975 / 10$ & 0.559 & & PWR \\
\hline & & 3 & $1994 / 3$ & 0.559 & & PWR \\
\hline & & 4 & $1997 / 7$ & 1.18 & & PWR \\
\hline & Sendai & 1 & $1984 / 7$ & 1.18 & & PWR \\
\hline & & 2 & $1985 / 11$ & 0.89 & & PWR \\
\hline & Tokai & 2 & $1978 / 11$ & 0.89 & 5.258 & PWR \\
\hline Genden & Tsuruga & 1 & $1970 / 3$ & 0.357 & & BWR \\
\hline & & 54 & $1987 / 2$ & 1.16 & 2.617 & PWR \\
\hline & & & & 48.96 & \\
\hline
\end{tabular}




\section{Appendix 5. Emergency Power Units}

\begin{tabular}{|l|l|l|l|}
\hline Tohoku & & & \\
\hline Higashi-Nigata & $25 \mathrm{MW} \times 2$ & Diesel & $2011 / 8$ \\
\hline Nigata 5 & $109 \mathrm{MW}$ & Natural Gas & $2011 / 7$ \\
\hline Nigara 6 & $34 \mathrm{MW} \times 1$ & Natural Gas & $2012 / 1$ \\
\hline Higashi-Nigata & $339 \mathrm{MW} \times 1$ & LNG & $2012 / 7$ \\
\hline Hachinohe & $274 \mathrm{MW} \times 1$ & Diesel & $2012 / 7$ \\
\hline Akita & $333 \mathrm{MW} \times 1$ & Diesel & $2012 / 7$ \\
\hline Tokyo & & & $2011 / 4$ \\
\hline Anezaki & $1.4 \mathrm{MW} \times 4$ & Diesel & $2011 / 4$ \\
\hline Sodegaura & $1.1 \mathrm{MW} \times 102$ & LNG & $2011 / 8-2012 / 7$ \\
\hline Chiba & $334 \mathrm{MW} \times 3$ & LNG & $2011 / 7$ \\
\hline Oi & $128 \mathrm{MW} \times 1$ & City Gas & $2011 / 7$ \\
\hline Oi & $81 \mathrm{MW} \times 1$ & City Gas & $2011 / 7$ \\
\hline Yokosuka & $26.3 \mathrm{MW} \times 7$ & Diesel & $2011 / 7$ \\
\hline Yokosuka & $25.3 \mathrm{MW} \times 3$ & Diesel & $2011 / 7$ \\
\hline Yokosuka & $23.2 \mathrm{MW} \times 3$ & Diesel & $2011 / 7$ \\
\hline Hitachinaka & $25.7 \mathrm{MW} \times 2$ & Diesel & $2011 / 7$ \\
\hline Hitachinaka & $1.5 \mathrm{MW} \times 64$ & Diesel & $2011 / 7$ \\
\hline Hitachinaka & $1.03 \mathrm{MW} \times 26$ & Diesel & $2011 / 7$ \\
\hline Hitachinaka & $0.85 \mathrm{MW} \times 93$ & Diesel & $2012 / 7$ \\
\hline Kajima & $268 \mathrm{MW} \times 3$ & Diesel/ City Gas & $2011 / 8$ \\
\hline Kawasaki & $128 \mathrm{MW} \times 1$ & LNG & \\
\hline
\end{tabular}


Appendix 6. Relation between Peak Load Reduction Rate and Total Demand Estimated by the Model

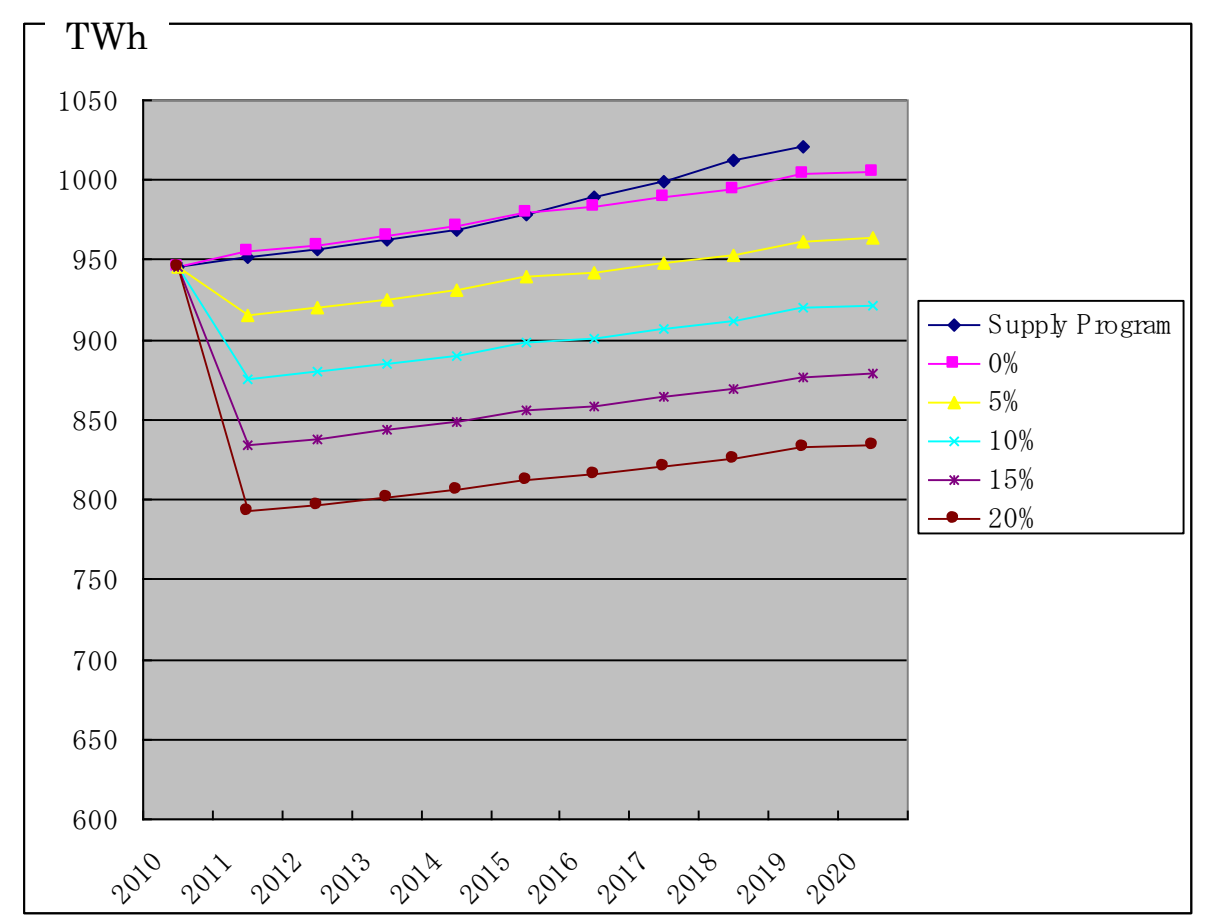


Appendix 7. Comparison of Total Demand (by peak load reduction rate) with Supply Program for FY2010

\begin{tabular}{|l|r|r|r|r|r|r|r|r|r|r|}
\hline FY & $\mathbf{2 0 1 0}$ & $\mathbf{2 0 1 1}$ & $\mathbf{2 0 1 2}$ & $\mathbf{2 0 1 3}$ & $\mathbf{2 0 1 4}$ & $\mathbf{2 0 1 5}$ & $\mathbf{2 0 1 6}$ & $\mathbf{2 0 1 7}$ & $\mathbf{2 0 1 8}$ & $\mathbf{2 0 1 9}$ \\
\hline $0 \%$ & 0 & 0.41 & 0.28 & 0.29 & 0.32 & 0.10 & -0.64 & -1.09 & -1.74 & -1.74 \\
\hline $5 \%$ & 0 & -3.73 & -3.85 & -3.84 & -3.82 & -4.02 & -4.73 & -5.16 & -5.79 & -5.79 \\
\hline $10 \%$ & 0 & -7.95 & -8.08 & -8.06 & -8.04 & -8.23 & -8.91 & -9.33 & -9.92 & -9.93 \\
\hline $15 \%$ & 0 & -12.27 & -12.39 & -12.38 & -12.36 & -12.54 & -13.19 & -13.59 & -14.15 & -14.16 \\
\hline $20 \%$ & 0 & -16.69 & -16.80 & -16.79 & -16.77 & -16.94 & -17.55 & -17.94 & -18.47 & -18.48 \\
\hline
\end{tabular}




\section{Glossary}

City Gas: Gas consumed in three categories (residential, commercial, and industrial) as distinct from gas consumed in the power generation sector.

EDMC: The Energy Data and Modeling Center

EPCO: Electric Power Corporation

FY: Fiscal Year

GW: a gigawatt is equal to one billion $\left(10^{9}\right)$ watts or 1 gigawatt $=1000$ megawatts

Hz: Hertz; a unit of elertic current frequency (cycles per second).

IAEA: International Atomic Energy Agency

IEEJ: The Institute of Energy Economics, Japan

JAPC: The Japan Atomic Power Company

Joint Power: Power companies that are jointly established by EPCOs and bulk customers.

LNG: Liquefied Natural Gas, i.e natural gas which is cooled to minus 161 Celsius and is a liquid at atmospheric pressure.

METI: The Japanese Ministry of Economy, Trade and Industry

Minato LNG Terminal: Sendai City Gas's LNG terminal.

Nihonkai LNG (Nihonkai LNG Co., Ltd.): Established by Tohoku EPCO, Development Bank of Japan, Niigata Prefecture, JAPEX and other private enterprises. Nihonkai LNG owns and operates LNG terminal in Niigata prefecture.

NISA: Nuclear and Industrial Safety Agency

NPS: Nuclear Power Station

Scram: A scram is an emergency shutdown of a nuclear reactor

Thermal power plant: An electicity generating plant using fossil fuel i.e. coal, oil, oil products or natural gas.

TWh: Terra Watt hour: the quantity of electrical energy generated in one hour at an output of one Terra Watt. 


\section{Bibliography}

Agency for Natural Resources and Energy, Follow-up Results of Electricity-Demand Measures in Summer (Verification of Approaches by Large and Small Electricity Customers and Households), December 2011.

Blackout caused by Tohoku Earthquake and the outlook for restoration' $21^{\text {st }}$ March,2011. http://www.tohoku-epco.co.jp/news/normal/1182682_1049.html

Central Electric Power Council, Electric Power Supply Program for Fiscal 2010, March 2010.

Central Environment Council. 'The Fourth Basic Environment Plan' http://www.env.go.jp/press/press.php?serial=15169

EDMC Handbook of Energy \& Economic Statistics2011' The Energy Conservation Center, Japan * Institute of Energy Economic, Japan, Short term energy outlook, $22^{\text {nd }}$ Dec. 2011.

Energy and Environment Council, 'Basic Policy (Draft): Toward the Presentation of Options for an Energy and Environment Strategy' 21st December 2011, http://www.npu.go.jp/policy/policy09/archive01_05.html\#haifu

Investigation Committee on the Accident at the Fukushima Nuclear Power Stations of Tokyo Electric Power Company, $26^{\text {th }}$ Dec 2011, Interim Report. http://icanps.go.jp/post-1.html

Japan Atomic Energy Commission, White Paper on Nuclear Energy

Japan Center for Economic Research, Short-term Forecast, $9^{\text {th }}$ March 2012

Japan Gas Association, State of Interruption of City Gas Supply, 11th March 2011. http://www.gas.or.jp/tohoku/press/pdf/20110313-01.pdf

METI: Framework of balancing power demand and supply during the summer season,

http://www.meti.go.jp/earthquake/electricity_supply/0408_electricity_supply_01_00.p df

METI: Interim report on data falsification of the nuclear plant self-inspection, 1st October, 2002. http://www.meti.go.jp/report/downloadfiles/g21108b012j.pdf

METI: Securing supply of LP Gas for Tohoku region' $5^{\text {th }}$ May 2011.

http://www.meti.go.jp/earthquake/gasoline/lp_gas_0505.pdf

METI Energy structure 2030, “Long Term Energy Policy”” June 2010.

METI:Fundamental Issues Subcommittee of the Advisory Committee on Energy and Natural Resources, 'Major Discussion Points Toward the Establishment of a New "Basic Energy Plan for Japan", 20 December 2011, http://www.meti.go.jp/english/press/2011/1220_05.html 
METI: 'Denryokujyukyu no Gaiyo'Denryokujyukyu no Gaiyo, Outline of Supply and Demand of Electricity.

METI, 'Follow-up Results of Electricity Supply-Demand Measures for this Summer', 14 Oct. 2011.

National Institute of Population and Social Security Research. Household Projections for Japan’ March 2008. http://www.ipss.go.jp/pp-ajsetai/j/HPRJ2008/t-page.asp

Natural Gas in Asia, edited J.Stern, Oxford Institute for Energy Studies, 2008.

NISA: http://www.nisa.meti.go.jp/stresstest/stresstest.html

NPS Cabinet Secretariat, Medium- and long-term road map for decommissioning of nuclear reactors 1 through 4 of Fukushima,.

http://www.cas.go.jp/jp/genpatsujiko/pdf/111221_01a.pdf

Oxford Institute for Energy Studies,

Takahashi, Hiroshi, 'Market Liberalization of Electric Utilities', Nihon Keizai Shimbun, 21 October 2011.

Damage and response' Ministry of Health, Labour and Welfare, Web site http://www.mhlw.go.jp/jishin/116-3-1.html 